\title{
Classicism as Foundation in Architecture: Ludwig Mies van der Rohe's Richard King Mellon Hall of Science and Michael Graves's Erickson Alumni Center
}

\author{
Elizabeth Stoloff Vehse \\ West Virginia University
}

Follow this and additional works at: https://researchrepository.wvu.edu/etd

\section{Recommended Citation}

Vehse, Elizabeth Stoloff, "Classicism as Foundation in Architecture: Ludwig Mies van der Rohe's Richard King Mellon Hall of Science and Michael Graves's Erickson Alumni Center" (2011). Graduate Theses, Dissertations, and Problem Reports. 848.

https://researchrepository.wvu.edu/etd/848

This Thesis is protected by copyright and/or related rights. It has been brought to you by the The Research Repository @ WVU with permission from the rights-holder(s). You are free to use this Thesis in any way that is permitted by the copyright and related rights legislation that applies to your use. For other uses you must obtain permission from the rights-holder(s) directly, unless additional rights are indicated by a Creative Commons license in the record and/ or on the work itself. This Thesis has been accepted for inclusion in WVU Graduate Theses, Dissertations, and Problem Reports collection by an authorized administrator of The Research Repository @ WVU. For more information, please contact researchrepository@mail.wvu.edu. 
Classicism as Foundation in Architecture:

Ludwig Mies van der Rohe's Richard King Mellon Hall of Science and Michael Graves’s Erickson Alumni Center

Elizabeth Stoloff Vehse

Thesis submitted to the

College of Creative Arts

at West Virginia University

in partial fulfillment of the requirements

for the degree of

Master of Arts

in

Art History

Kristina Olson, M.A., Chair Janet Snyder, Ph.D.

Robert Bridges, M.F.A.

Division of Art and Design

Morgantown, West Virginia

2011

Keywords: Classical influence on Modernism, classical influence on Postmodernism

Copyright 2011 Elizabeth Stoloff Vehse 


\title{
Abstract \\ Classicism as Foundation in Architecture: \\ Ludwig Mies van der Rohe's Richard King Mellon Hall of Science and Michael Graves's Erickson Alumni Center
}

\author{
Elizabeth Stoloff Vehse
}

The French Cubist painter and writer Amédée Ozenfant suggested that "Deep in every revolution, discreetly hidden, resides a classicism which is a form of constant.” Twentiethcentury Modern and Postmodern architecture are no exceptions to this rule. Basic to both movements is the use of classical reference as a foundation for communication with the viewer. This study shows how classical elements and ideas inform the work of Modern and Postmodern architects. Employing classicism as a framework for the holistic reinterpretation of a set of established values (Modernism), or as quotation that is part of a symbolic cultural language (Postmodernism), the architect is well served by the adoption of this time-honored source at the core of his or her work.

Modern architect Ludwig Mies van der Rohe and Postmodernist Michael Graves serve as representative examples of each of these ways of using classical elements and ideas to ground their work. This study looks at the development of each artist in the context of his artistic movement and details classical influences on his work, focusing ultimately on one building designed by each architect: Mies’s Richard King Mellon Hall in Pittsburgh, Pennsylvania (196268); and Graves’s Erickson Alumni Center in Morgantown, West Virginia (1984-86). While both architects' work is much discussed by historians and critics, this is the first in-depth study of these two buildings through the lens of classicism. Each building is characteristic of its respective architect's use of ancient Greek and Roman ideas. 


\section{Acknowledgements}

Thank you to Kristina Olson and Janet Snyder for their encouragement, persistence, and respect over the course of my work and to them and to Bob Bridges for their academic expertise and assistance with this thesis. Also, thank you to Michael Slaven for his photographs; to Claude Sigley for help with formatting; to Anita Mayer for reminding me of the significance of this degree; and to Ted and Nathan Vehse for their patience and support. 


\section{Table of Contents}

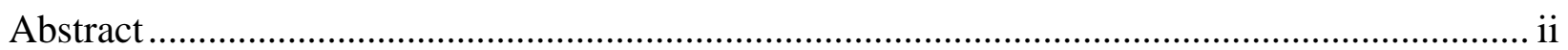

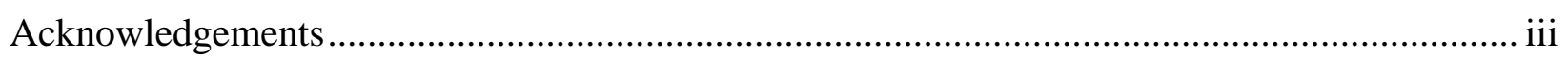

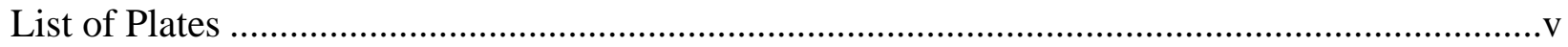

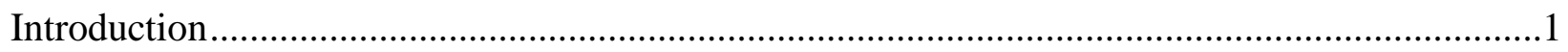

Chapter 1: Ludwig Mies van der Rohe, Modernism, and Classicism .......................................8

Chapter 2: Richard King Mellon Hall of Science ................................................................30

Chapter 3: Michael Graves, Postmodernism, and Classicism ...............................................51

Chapter 4: Erickson Alumni Center..............................................................................67

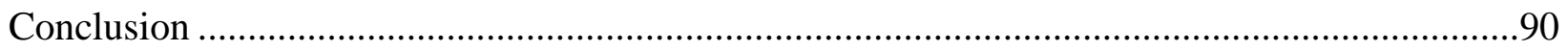

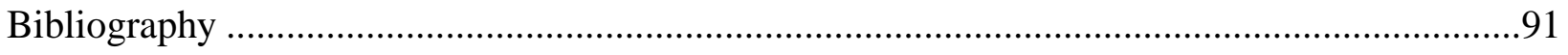




\section{List of Plates}

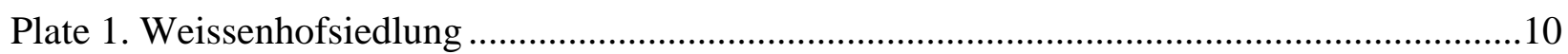

Plate 2. Charles Garnier, Palais Garnier (Paris Opera House)..........................................................11

Plate 3. Louis Sullivan with Dankmar Adler, Guaranty Building, Buffalo New York..................12

Plate 4. Adolf Loos, Former Goldman \& Salatsch Store, Michaelerplatz, Vienna .........................12

Plate 5. Adolf Loos entry, 1922 Chicago Tribune Tower contest ...................................................13

Plate 6. Sir William Chambers' imagined wooden prototype of the Doric order...........................15

Plate 7. Mies van der Rohe, Kroller-Muller House drawing ...........................................................16

Plate 8. Palatine Chapel, Aachen, Germany …………….................................................

Plate 9. Peter Behrens, A.E.G. Turbine Factory, Berlin, Germany .................................................21

Plate 10. Maison Carree, Nimes, France..........................................................................................

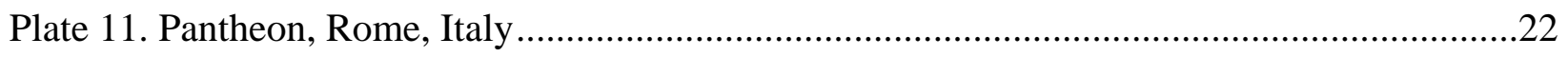

Plate 12. Walter Gropius with Adolf Meyer, Fagus Shoe Factory, Alfeld, Germany .....................23



Plate 14. Mies van der Rohe, Proposed Office Building ..................................................................27

Plate 15. Mies van der Rohe, Proposed Office Building ..................................................................27

Plate 16. Mies, Farnsworth House, Plano, Illinois.............................................................................28

Plate 17. Mies, Richard King Mellon Hall of Science, Pittsburgh, Pennsylvania..........................31

Plate 18. View from Mellon Hall over the hills of Pittsburgh ........................................................32

Plate 19. View from Parthenon over the hills of Athens, Greece ......................................................32

Plate 20. Parthenon, Athens, Greec ……………………………………………………..............33

Plate 21. Friedrich Gilly's plan for a monument to Frederick II of Prussia.......................................34

Plate 22. Karl Friedrich Schinkel, Altes Museum, Berlin Germany …….......................................34

Plate 23. Mies, Proposed Monument to German Chancellor Bismarck ..........................................34 


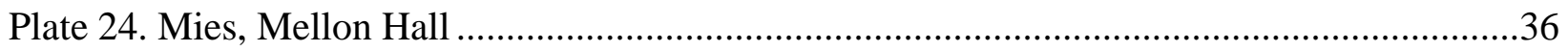

Plate 25. Mies, Mellon Hall colonnade..........................................................................................

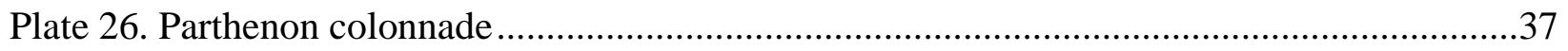

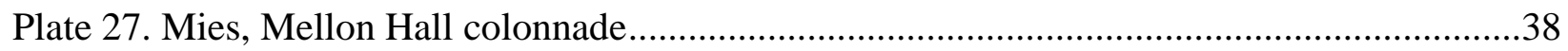

Plate 28. Mies, Mellon Hall colonnade......................................................................................38

Plate 29. Mies, Mellon Hall steel column or pilotis …………………....................................39

Plate 30. Mies, Mellon Hall steel column or pilotis …………………….....................................40

Plate 31. Temple of Apollo column ruins, Delphi .......................................................................40

Plate 32. Ruins, Agora, Athens .........................................................................................

Plate 33. Mies, Mellon Hall repeated window bays .......................................................................43

Plate 34. Mies, Mellon Hall grid design ....................................................................................

Plate 35. Mies, Mellon Hall decorative I-beams.............................................................................44

Plate 36. Parthenon architrave with metopes and triglyphs ............................................................45

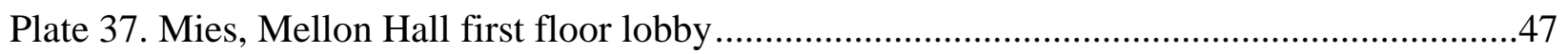

Plate 38. Mies, Mellon Hall first floor lecture hall wall .................................................................48

Plate 39. Mies, Mellon Hall first floor Roman brick wall .................................................................48

Plate 40. Mies, Mellon Hall first floor lobby ...............................................................................49

Plate 41. Greek temple floor plan with highlighted cella or inner chamber ....................................49

Plate 42. Le Corbusier with Kunio Maekawa, Junzo Sakakura and Takamasa Yoshizaka, National Museum of Western Art, Tokyo, Japan..............................................................52

Plate 43. Michael Graves, Hanselmann House, Fort Wayne, Indiana..............................................52

Plate 44. Peter Eisenman, Falk House, Hardwick, Vermont ............................................................53

Plate 45. Michael Graves, Santo Stefano Rotondo, Interior, Caelian Hill, Rome, Italy..................55

Plate 46. Graves, Santa Rosalina, Palestrina, Italy ……………………………………..............56

Plate 47. Graves, Flavian Amphitheatre, Colosseum, No. 1, Imperial Forums, Rome, Italy .........58

Plate 48. Robert Venturi, Vanna Venturi House, Chestnut Hill, Pennsylvania...............................58 
Plate 49. Graves, Plocek House, Warren, New Jersey.

Plate 50. Plocek House living room with columns ……………………………........................61

Plate 51. The Warehouse, Graves's home living room with column, Princeton, New Jersey ......62

Plate 52. Graves, Post Office, Celebration, Florida ..........................................................................62

Plate 53. Graves, The Portland Public Service Building ...................................................................66

Plate 54. Graves, Erickson Alumni Center, West Virginia University, Morgantown, West Virginia.......................................................................................................................67

Plate 55. Erickson Alumni Center pitched, shingled roof ...............................................................69

Plate 56. Erickson Alumni Center chimney..................................................................................

Plate 57. Erickson Alumni Center faux pane windows ....................................................................70

Plate 58. Erickson Alumni Center downspout and trellises.......................................................71

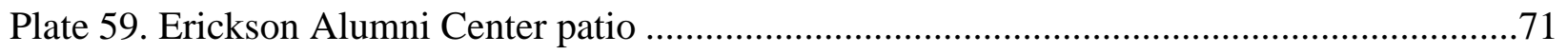

Plate 60. Erickson Alumni Center Great Hall................................................................................72

Plate 61. Graves painting with chimney pots.................................................................................73

Plate 62. Treasury of Athens, Delphi, Greece ..............................................................................74

Plate 63. Erickson Alumni Center with tholus shape over entrance ................................................75

Plate 64. Architect's plan for tholus supported by two columns ......................................................75

Plate 65. Choragic Monument of Lysicrates, Athens, Greece ...........................................................76

Plate 66. Country house of a noble Venetian...................................................................................77

Plate 67. Graves's inkwells replicas of the Temple of Vesta …………...........................................78

Plate 68. Temple of Venus, Hadrian’s Villa, Tivoli, Italy .............................................................79

Plate 69. Temple of Venus detail, metopes and triglyphs..............................................................79

Plate 70. Erickson Alumni Center frieze, Great Hall......................................................................

Plate 71. Erickson Alumni Center exterior wall decoration ..............................................................81

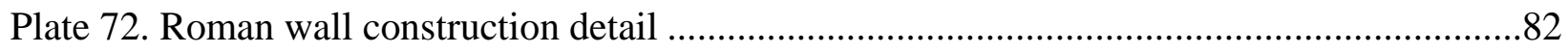

Plate 73. Theodosian Wall built under Roman Emperor Constantine, Istanbul, Turkey................82 
Plate 74. Erickson Alumni Center downstairs hallway “colonnade” with piers...........................84

Plate 75. Erickson Alumni Center Great Hall ceiling beams and pedimental shapes ..................84

Plate 76. Erickson Alumni Center Great Hall fireplace.............................................................85

Plate 77. Graves table with dentil molding and “column” legs ............................................87

Plate 78. Erickson Alumni Center rear façade ....................................................................87

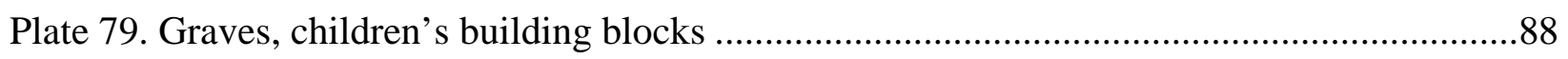

Plate 80. Tomb of Agamemnon, Mycenae, Greece ..............................................................89 


\section{Introduction}

The French Cubist painter and writer Amédée Ozenfant suggested: “Deep in every revolution, discreetly hidden, resides a classicism which is a form of constant.”1 Twentieth-century Modern and Postmodern architecture are no exceptions to this rule. Basic to both movements is the use of classical reference as a foundation for communication with the viewer. Employing classicism as a framework for the holistic reinterpretation of a set of established values (Modernism), or as quotation that is part of a symbolic cultural language (Postmodernism), the architect is well served by the adoption of this time-honored source at the core of his or her work.

Modern architect Ludwig Mies van der Rohe and Postmodernist Michael Graves serve as representative examples of each of these ways of using classical elements and ideas to ground their work. This study will look at the development of each artist in the context of his artistic movement and detail classical influences on his work, focusing ultimately on one building designed by each architect: Mies’s Richard King Mellon Hall in Pittsburgh, Pennsylvania (196268), and Graves’s Erickson Alumni Center in Morgantown, West Virginia (1984-86). While both architects' work is much discussed by historians and critics, this is the first lengthy study of these two buildings, each of which is characteristic of its respective architect's use of classicism.

The Modernists usually are cited as borrowing from the Greeks; the Postmodernists from the Romans. Although Le Corbusier’s writing demonstrates his loyalty to Greek architecture, Mies’s sources and inspirations are not so clearly delineated. Like the Greeks, his work was focused on the search for purity and perfection. He appears to have been more interested in finding a system by which he could standardize his grid, his basic building design, than in expressing any particular influence. Like the Romans, he borrowed from the Greeks in developing building techniques based on new technology. He cited the Romans in his writing (of

\footnotetext{
${ }^{1}$ William J. R. Curtis, Modern Architecture Since 1900 (London: Phaidon Press Limited, 1996), 140-42.
} 
which there is not much) as much as he did the Greeks; grew up under the influence of the Roman architecture by which he was surrounded; and spoke about the beautiful simplicity of the geometric repetition in the Roman aqueducts he saw during an early trip to Italy. He created a modern amalgamation of classical geometry, symmetry, and detail. Although the Greek inclination toward the theoretical characterizes his work, it does not completely define it.

Graves embraces the Roman eclecticism that resulted from their borrowing from the Greeks and others. He rejects the Modernist (and Greek) search for the ideal, trying instead to bring architecture back to its roots. He does not, however, embrace the Roman obsession with power, gravity, or piety. Even in his return to the (Roman) emphasis on solid walls, he tricks the viewer with a lack of authenticity in his use of materials. Heavy walls turn out to be Styrofoam, and relieving arches do not bear any weight. Graves does identify more with the Romans, but, like Mies, he relies on that amalgamation that westerners call "classicism.”

The influence of ancient Greek and Roman architecture on Modern and Postmodern architects is mentioned often in scholarly literature, but there are few studies that focus on it entirely. Few examine in detail the profound effect classicism has had on these two architects. None contain sustained studies devoted to its influences on particular works by Mies van der Rohe and Michael Graves. It is interesting to note that Graves himself does write about the contrast between his own work and that of Mies. In these brief allusions, Graves points to Mies as an example of the Modernism that he sees as problematic. (It is likely that Mies would have drawn similar contrasts with Graves’s work, had he lived to see it.)

The writings of Graves and Mies (mostly interviews of Mies, rather than works written by him) will be addressed in this study. What follows is a brief discussion of some other works that address classicism's influence on these two architects. 
There are a multitude of books from the 1960s, '70s, and '80s on Mies, written by wellknown historians and critics. ${ }^{2}$ These books are mainly historical accounts of the architect's work and mention classical influences mostly in an off-hand way. There is quite a bit of redundancy in the literature, focusing on Mies's major buildings and making brief reference to his use of classical Greek and Roman influences. The brief discussions of classicism support this study's thesis, but they are general.

John Summerson’s 1963 The Classical Language of Architecture is a relevant, condensed investigation of the definition of classical architecture and its application to later periods in the history of architecture, ending with the Modern period. He discusses the ways in which classical thought influenced later architecture and can be abstracted (to a point) and still be "classical." Summers argues that it is a mistake to try to define classicism,” because it has so many iterations. His book contains no detailed description of how any one building is classical in its modern interpretation.

A few shorter studies, such as William Curtis's "Modern Transformations of Classicism" in the August 1984 issue of Architectural Review, speaks more directly to the Modernist use of classical ideas. It provides perhaps the best explanation of how classicism informed modern architecture, with brief examples of its influence on the most influential modern architects. It touches on classical ideals, architectural elements, and geometry, and points out that the Modernists were not rejecting history but rather, reinterpreting it in modern terms with new materials and a new focus on innovation in a machine age. It is a clearly articulated but brief explanation of classical influences on modern architecture.

\footnotetext{
${ }^{2}$ Peter Blake, The Master Builders: Le Corbusier, Mies van der Rohe, Frank Lloyd Wright (New York: W. W. Norton \& Company, 1960, 1976); John Summerson, The Classical Language of Architecture (Cambridge, MA: The MIT Press, 1963); Werner Blaser, Mies van der Rohe (New York and Washington: Praeger Publishers, 1965, 1972); and Franz Schulze, Mies van der Rohe: A Critical Biography (Chicago and London: The University of Chicago Press, 1985).
} 
Literature from the 1990s to today is more analytical in its investigation of this subject and is able to incorporate, in some cases, a comparison of the ways in which Modernists and Postmodernists addressed classicism. ${ }^{3}$ Detlef Mertins's The Presence of Mies, as an edited volume that began as a symposium on Mies, combines chapters by scholars on a variety of interesting topics, some related to the classical influence on the architect. Moisés Puente’s account of interviews with Mies on a wide range of subjects provides insight into the architect's own opinions.

George Herseys The Lost Meaning of Classical Architecture (MIT Press), according to a review by David Clarke in The Architecture of Alienation, ${ }^{4}$ argues that, in order to really appreciate and employ classical traditions, an architect has to "adopt its 'head' - its whole way of thinking. He or she must fully understand its language and culture, not merely take ideas or elements. Hersey, therefore, calls Mies a "shadow classic” and argues that Mies had no right to build based on rituals that are 2,000 years out of date. He calls Postmodernism "achingly intelligent while carefully unintelligible” (p. 186). He asserts that today’s architects have the chance to surpass both Renaissance and Periclean Athens and their empty imitation by building meaning, as Athens did, and trying to forget the dead end or ornament and decoration.

In Kate Nesbitt's 1996 edited volume, Theorizing a New Agenda for Architecture, ${ }^{5}$

Michel Foucault discusses the terms "class," "classical," and "classicism" and the relationship of Modern architecture to classical style and idea. The notes are really the most relevant to the discussion of how to define "classic," "classical," and "classicism," as they discuss the confusion

\footnotetext{
3 Detlef Mertins, ed., The Presence of Mies, (New York: Princeton Architectural Press, 1994); Fik Hearn, Ideas That Shaped Buildings (Cambridge, MA, and London: The MIT Press, 2003); Moisés Puente, ed., Conversations with Mies van der Rohe (New York: Princeton Architectural Press, 2008).

${ }^{4}$ David Clarke, The Architecture of Alienation (New Brunswick and London: Transaction Publishers, 1994).

${ }^{5}$ Kate Nesbitt, ed., Theorizing a New Agenda for Architecture: An Anthology of Architectural Theory 1965-1995 (New York: Princeton Architectural Press, 1996).
} 
that is common with these words and their interchangeable usage, be it right or wrong. The following idea is interesting in its illustration of Modernism's acceptance as a style, because perhaps it is the Modern interpretation of classical elements and ideas that made it so acceptable: "It was not until the late twentieth century that the classical could be appreciated as an abstract system of relations. Such recognition occurred because the architecture of the early twentieth century itself came to be considered part of history.”

Thomas Doremus's Classical Styles in Modern Architecture from Colonnade to

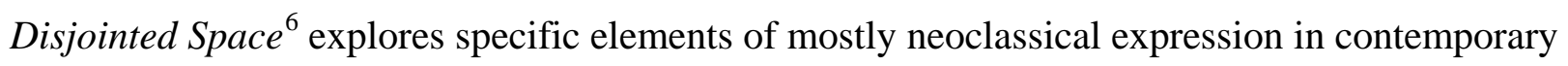
American architecture. He cites mostly public buildings in Washington, D. C. The different definitions of "classical" are addressed at the beginning of the book.

A 2009 master’s thesis by Edward Lifson from the University of Southern California directly addresses this subject but in the limited scope of architecture passed down from the Greeks, through Schinkel, to Mies. "How Truth and Beauty Moved from the Classical to the Modern. From Athens to Berlin to Chicago: From the Acropolis to Schinkel to Mies” traces the history of classicism in this direct line. The content is interesting but the treatment rather superficial.

Still, there is no lengthy study devoted to the topic of ancient classical influence on Modernism. There is more literature on the relationship of classicism to the Postmodernists, especially Michael Graves. While Graves himself does talk about his use of classical elements as vocabulary, these discussions are usually incorporated into studies devoted to other topics. Many of the most well-known books feature a large number of his works but do not discuss in detail

\footnotetext{
${ }^{6}$ Thomas Doremus's Classical Styles in Modern Architecture from Colonnade to Disjointed Space (New York: Van Nostrand, 1994).
} 
their classical influences. ${ }^{7}$ The exception is Kenneth Powell’s Graves Residence, ${ }^{8}$ which address the various classical elements Graves has incorporated into this continuing project over the years. Brian Ambroziak’s Michael Graves: Images of a Grand Tour, ${ }^{9}$ reproduces the multitude of Graves’s drawings and photographs from his early years in Rome, illustrating how much classical architecture must influence his work, but there is not much discussion of the influence of what he saw on particular buildings he has designed.

\footnotetext{
${ }^{7}$ Karen Vogel Wheeler, Peter Arnell, and Ted Bickford, eds., Michael Graves: Projects and Buildings 1966-1981 (New York: Rizzoli, 1982); Karen Vogel Nichols, Patrick J. Burke, and Caroline Hancock, eds., Michael Graves: Buildings and Projects 1982-1989 (New York: Princeton Architectural Press, 1990).

${ }^{8}$ Kenneth Powell, Graves Residence: Michael Graves (London: Phaidon Press Limited,1995). 2005).

${ }^{9}$ Brian Ambroziak, Michael Graves: Images of a Grand Tour (New York: Princeton Architectural Press,
} 
Technology is rooted in the past.

It dominates the present and tends into the future.

It is a real historical movementone of the great movements which shape and represent their epoch.

It can be compared only with the Classic discovery of man as a person, the Roman will to power...

Whenever technology reaches its real fulfillment, It transcends into architecture.

Mies van der Rohe, Architecture and Technology 


\section{Ludwig Mies van der Rohe, Modernism, and Classicism}

Ludwig Mies van der Rohe (1886-1969) was one of the most influential architects of the twentieth century. Along with his contemporaries, first in Europe and later in the United States, he championed the new machine-age aesthetic that became the architectural standard for most of twentieth-century western architecture and became known as the International Style. Along with the other Modernists, he reinterpreted classical Greek and Roman architecture through the use of new building materials, such as steel and reinforced concrete, and through technological advances developed at the end of the nineteenth century.

Reacting to the social, cultural, and political contradictions brought about by World War I, Modern architects of the 1920s attempted to build a new world through architecture. They wanted to create a fresh vision of humanity through the purifying influences of their art, through a reinterpretation of the transcendent vision of the human spirit embodied in that ancient worldview. They believed that a new architecture, based on that time-tested vision but transformed into modern materials, could transcend conflict and national boundaries and unite western society. They looked to a new architecture that, through this combination of new ideas and their innovative use, could lift society to a higher level of existence and provide a model for clean, efficient, enlightened living. It would provide a clean slate. In 1924, Mies offered the following opinion of how to accomplish this efficiency:

The steel industry pioneered the manufacture of fabricated parts ready for assembly, and today the lumber industry is trying the same thing. In all other building, however, the roughwork and most of the interior fittings are carried out in the traditional way-by hand work.... Industrialization of the processes of construction is a question of materials. Our first consideration, therefore, must be to find a new building material... which can be industrially manufactured and processed and which will be weatherproof, soundproof and insulating.... All the parts will be made in a factory and the work at the site will consist only of assemblage, requiring extremely few man-hours. ${ }^{10}$

\footnotetext{
${ }^{10}$ Ludwig Mies van der Rohe, The Industrialization of Building Materials, trans. Philip Johnson (NewYork: Museum of Modern Art, 1947).
} 
Mies also said that it was not the new materials that were necessarily superior but what architects made of them. For many of the Modern architects, the transparent use of steel, glass, and reinforced concrete became fundamental to their work.

The artists of this Modern school, among whom Mies van der Rohe was a dominant figure, were engaged in a passionate search for a means to achieve their goals. Crucial to the development of this school were the architects involved in the Deutscher Werkbund exhibition of 1927 in Stuttgart, Germany (plate 1). This group a group of men who had been working both together and separately to develop a minimalist, cleaner architectural machine-aesthetic. Mies was asked by the group to coordinate the design of an exhibition of housing prototypes by the various architects, arranged in a single estate, or Siedlung. Architects from Germany, Holland, Belgium, and France participated by exhibiting their housing designs. Notable among them were German architects Walter Gropius, Ludwig Hilberseimer, and Bruno Taut and the Swiss-born architect Le Corbusier. Their designs, considered by many too “communist” in their conformity of style, caused a stir among both the left and the right. The Weissenhofsiedlung exhibition, with its common theme of "white, cubic volumes, striped planar shapes, open plans, and machine-age details"11 was a defining event for the style that would come to be called the "International Style.” Several of these architects, along with artists Marcel Breuer and Lazlo Moholy-Nagy, also influenced Modern style through their work with the German Bauhaus.

\footnotetext{
${ }^{11}$ Curtis, Modern Architecture Since 1900, 198.
} 


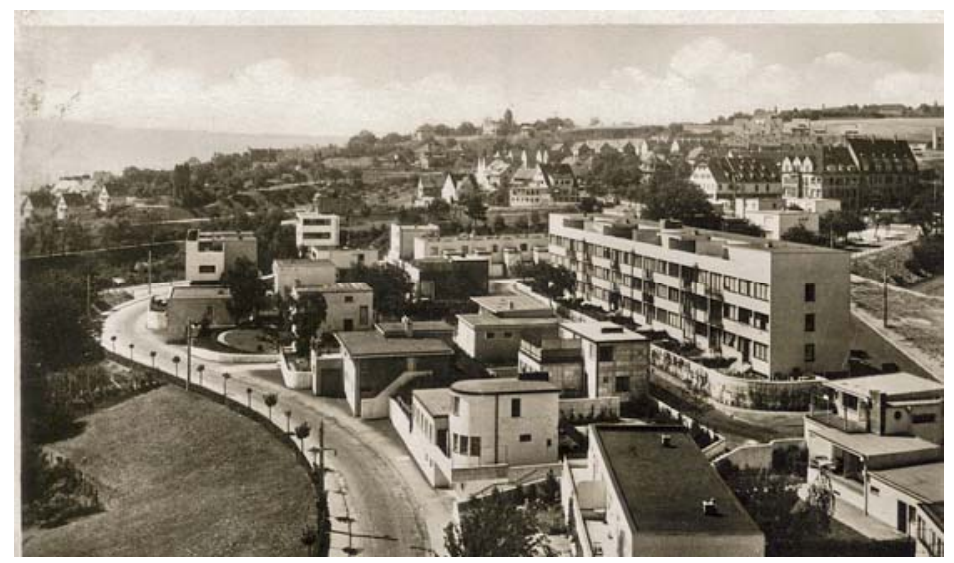

Plate 1. Weissenhofsiedlung, Deutscher Werkbund exhibition, Stuttgart, 1927

Deeply grounded in the humanism of ancient Greece and Rome, these architects sought a modern expression of values that had endured the centuries to become a model for western philosophy, education, science, and politics. These values centered on human concerns: democracy and the social and intellectual possibilities attainable through imaginative speculation and questioning. A time-honored source, classical architecture, suited their goals, as it had architects for generations before them.

Reacting against the more elaborate Beaux-Arts style of the eighteenth and nineteenth centuries (plate 2), early twentieth-century architects such as Adolf Loos and Peter Behrens relied on a simplified interpretation of classical language and spirit. In the United States, Louis Sullivan's skyscrapers and Frank Lloyd Wright's houses also exemplified a reinterpretation, in radically simplified design, of the tripartite theme of the classical column. Sullivan’s 1985 Guaranty Building in Buffalo, New York (plate 3), has a defined base, a shaft section consisting of most of the building, and a roof with a cornice that serves as a capital, extending out over the sides of the building. The façade, with its regular vertical bands of masonry between the window bays can be seen as a flattened pattern of column flutes. Adolf Loos’s 1910-11 Goldman \& Salatsch Store in Vienna (plate 4) consists of the same tripartite design, and his 1922 tongue-and- 
cheek proposal for the Chicago Tribune Tower competition (plate 5) is an obvious imitation of a classical column.

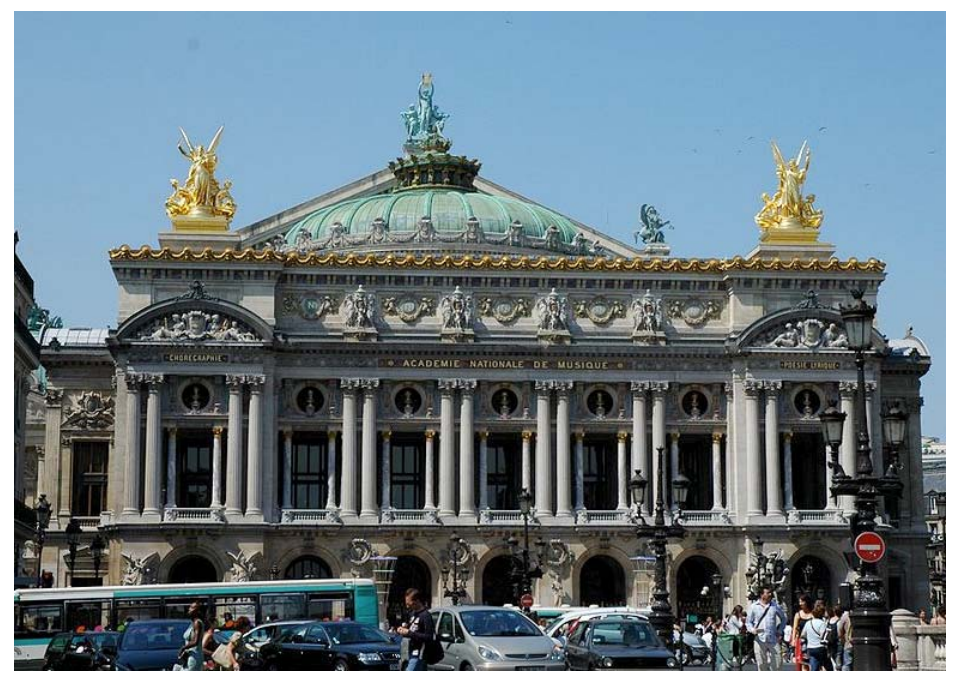

Plate 2. Charles Garnier, Palais Garnier (Paris Opera House), 1875 


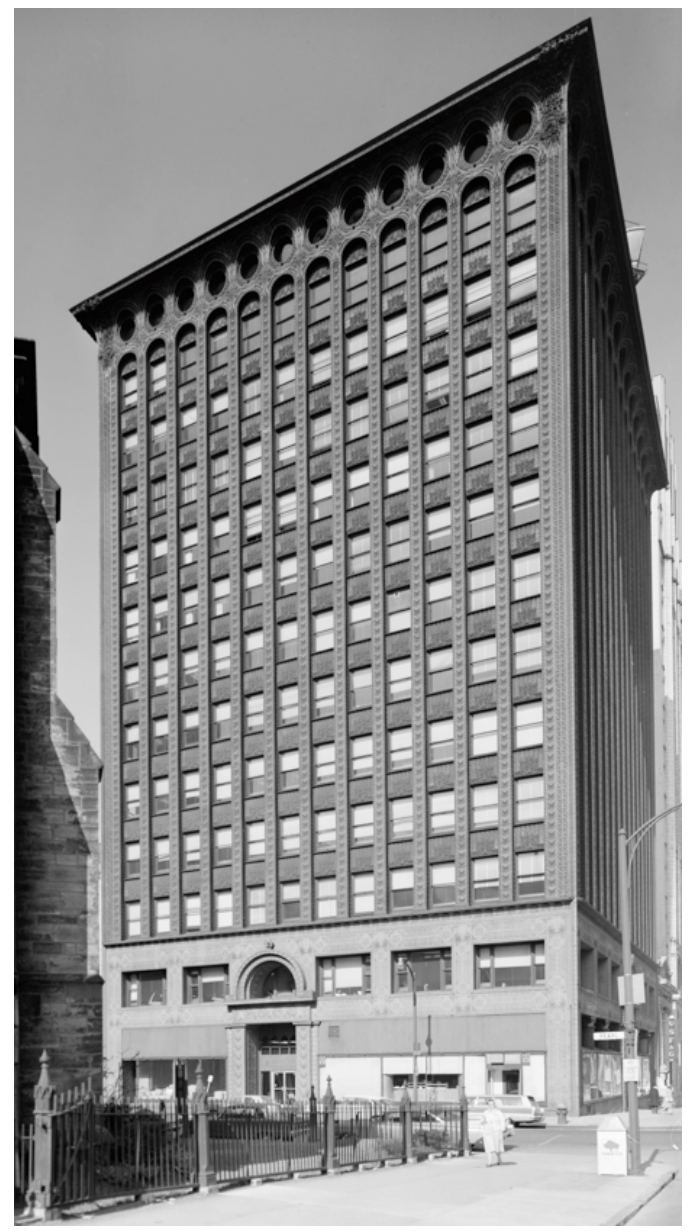

Plate 3. Louis Sullivan with Dankmar Adler, Guaranty Building, Buffalo, New York, 1894

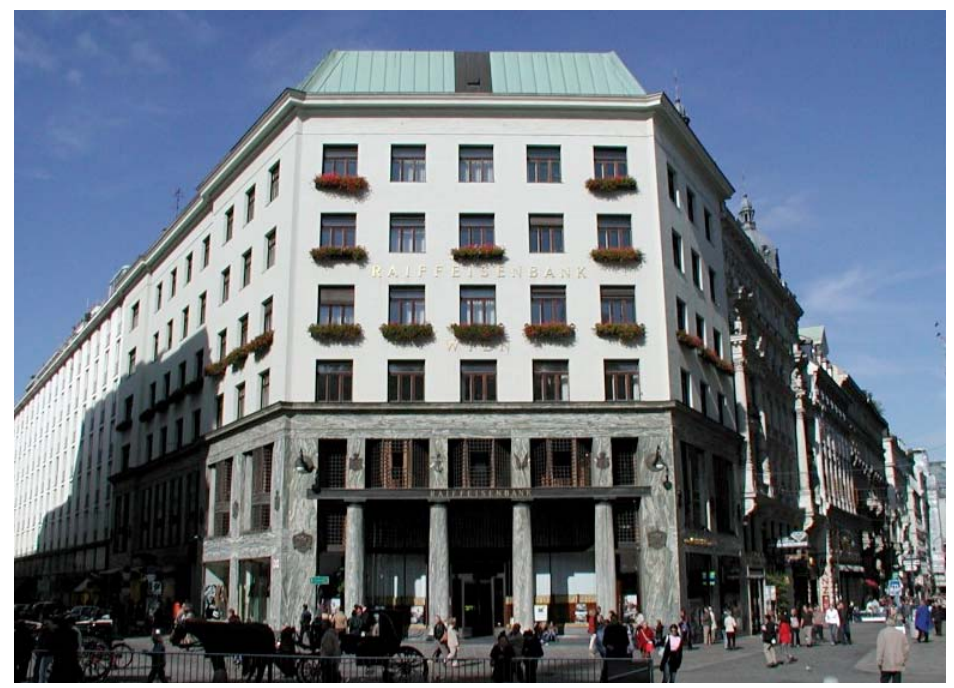

Plate 4. Adolf Loos, Former Goldman \& Salatsch Store, Michaelerplatz, Vienna, 1910-11 


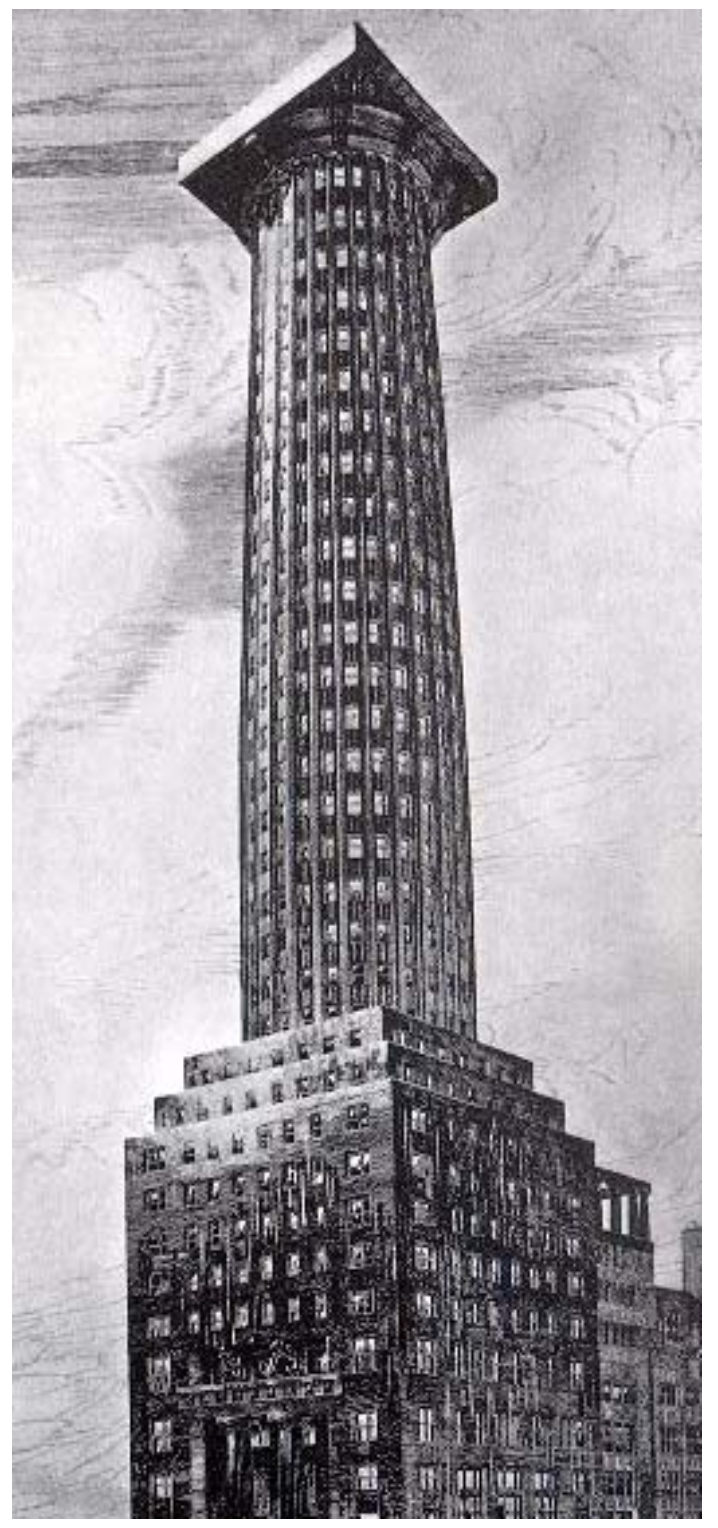

Plate 5. Loos entry, 1922 Chicago Tribune Tower contest

Architectural historian William Curtis emphasizes artists’ continual return to classical sources.

Beyond allusions and ordering devices, the engagement with "classical values" tended to imply a search for "ideal” forms and "immutable" qualities. The painter and writer Amédée Ozenfant suggested: “Deep in every revolution, discreetly hidden, resides a classicism which is a form of constant."12

\footnotetext{
${ }^{12}$ Ibid., 140-42.
} 
"The [classical] orders [had come] to be regarded as the very touch-stone of architecture...embodying all the ancient wisdom of mankind in the building art."13 Looking to interpret this source to suit a modern role, rather than simply to borrow stylistic elements, they stripped this source to its essential core and adapted its basic ideas to their modern social and technological environment. Classical ideals were well suited to this purpose, to this interpretation that kept the ancient organizational principles intact but updated their manifestation.

This conception of interpreting classical architectural ideas in new material refers all the way back to what is believed to be the origin of the classical orders. As International Style architects transformed classical elements (made of stone) into modern ones (made of steel) serving a like purpose, so did ancient builders transform primitive timber construction into a stone equivalent.

In his Ten Books on Architecture, ${ }^{14}$ written c. $30-20$ B.C.E., Marcus Vitruvius Pollio wrote that the classical orders originated in wood and then were translated into stone. He described how wooden posts were capped by a horizontal architrave connecting the posts, with the ends of perpendicular beams lying on tip of the horizontal post. These beam ends came to be represented by triglyphs; the spaces between became meteopes; and the roof sloped to allow for rain runoff, leading to the formation of a pediment. He went on to detail how each element of the wooden prototype came to be part of the classical orders ${ }^{15}$ (plate 6).

\footnotetext{
${ }^{13}$ John Summerson, The Classical Language of Architecture (Cambridge, MA: The MIT Press, 1963), 11.

${ }^{14}$ Vitruvius, Ten Books on Architecture, trans. Ingrid D. Rowland (Cambridge: Cambridge University Press,

${ }^{15}$ Fik Hearn, Ideas That Shaped Buildings (Cambridge, MA, and London: The MIT Press, 2003), 98-9.
} 1999). 


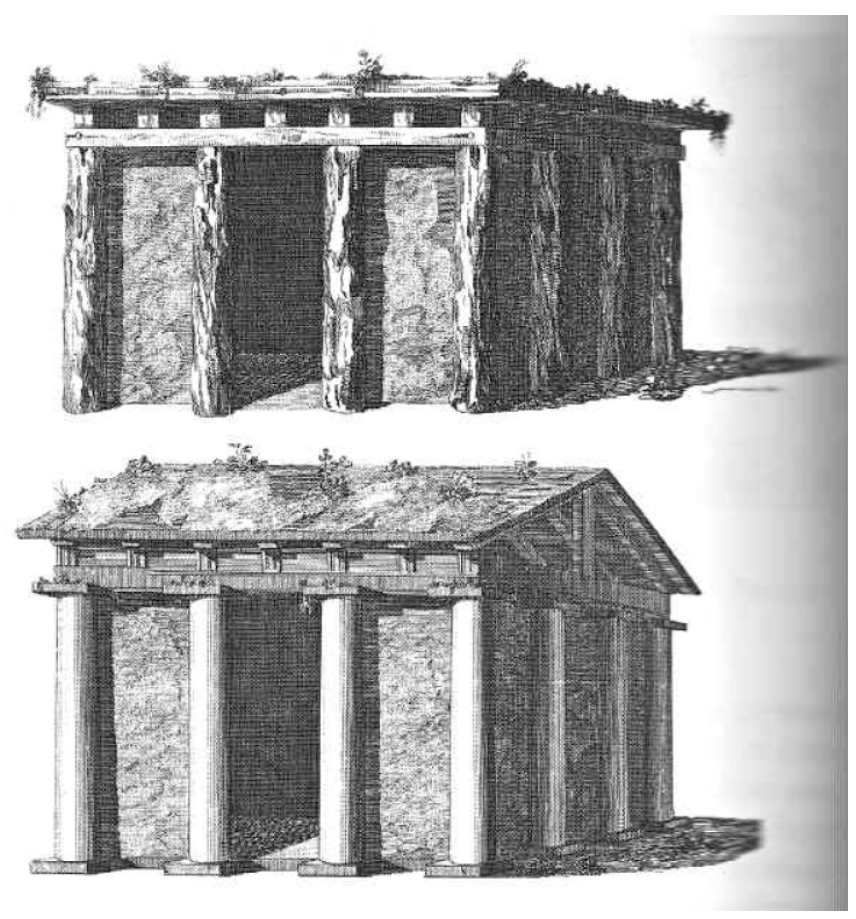

Plate 6. Sir William Chambers' imagined wooden prototype of the Doric order from A Treatise on the Decorative Part of Civil Architecture, 1791

What was important to these very early ancient architects was preserved by giving it their own “modern” interpretation in a modern material. Art historian John Summers wrote

It is quite certain that the Doric order derives its form from a primitive type of timber construction. Vitruvius tells us as much. When you are looking at a Doric order executed in stone, you are looking, in effect, at a carved representation of a Doric order constructed of wood. Not a literal representation, of course, but a sculptural equivalent. The earliest temples in the ancient world were built of wood...those of special sanctity...came to be rebuilt in stone...stone temples copied the copies... and so it went on till the whole thing became a static and accepted formula [the column with its shaft and capital, the frieze, the pediment, and so on]. ${ }^{16}$

Mies van der Rohe became a central, indeed a defining figure in the development of the new International Style architecture. Perhaps more than any of his colleagues, he embraced and realized this modern reinterpretation of classical building in modern terms. Perhaps for this reason, it is Mies’s work, among the Modernists, that is the most accessible or readable as a reinvention of classical ideas in modern terms. His work exemplifies the formal integration of

\footnotetext{
${ }^{16}$ Ibid., 12.
} 
classical elements, using twentieth-century materials and technology. His drawing for the 1912 Kroller-Muller House in the Hague (plate 7) shows his early interpretation of classical elements through reductivist geometry and simplified columns.

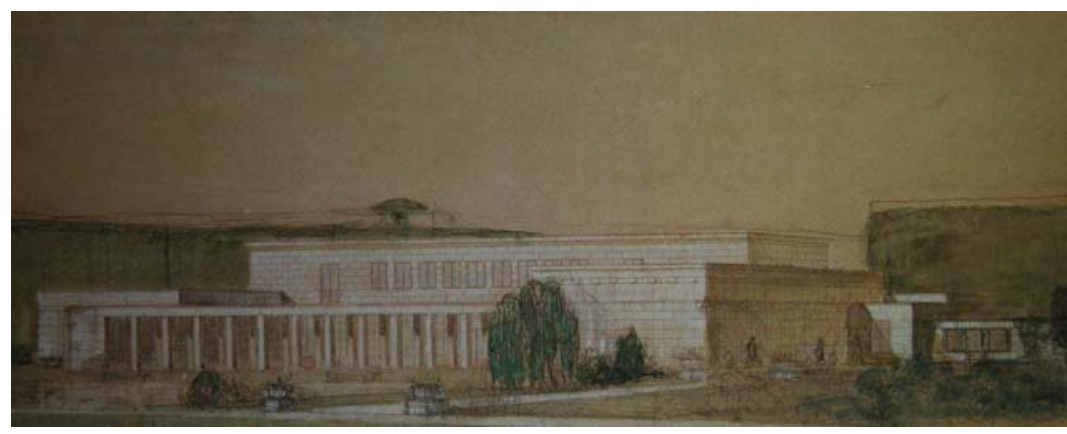

Plate 7. Mies van der Rohe, Kroller-Muller House drawing, 1912

Throughout his career, Mies strove to set a standard of visual symmetry, balance, and order, a standard based on proportions appropriate to human aspirations. He defined his architecture in these terms and dedicated himself to what he saw as a spiritual pursuit of physical perfection. Using twentieth-century building materials, he referred back to aesthetic values embodied in the classical age and measured his own work by the standards of an ancient model. He read Plato and considered the great philosopher's ideas in his use of new materials, especially in his use of glass in combination with steel. "We are reminded again of the crucial relationship which Mies, the older he grew, saw between material fact and immaterial spirit, between the thing and its essence."17 Mies valued, above all, reason in architecture but saw his work also as a spiritual quest. $^{18}$

Mies van der Rohe grew up in Aachen, Germany, surrounded by the traditional building trades and an abundance of medieval religious architecture. Son of a stone mason, he apprenticed as a draughtsman and designer in this town that had been the first capitol of the Holy Roman

\footnotetext{
${ }^{17}$ Schulze, Mies van der Rohe, 103.

${ }^{18}$ Puente, Conversations with Mies van der Rohe, 56.
} 
Empire. His own school, which he attended through age thirteen, was founded in Aachen by the Roman emperor Charlemagne in the early ninth century A.D,${ }^{19}$ the same century as the Aachen Palatine Chapel (plate 8). The influence of this chapel can perhaps be seen in Mies's later use of fine materials on the interior of his later buildings. The architecture historian Franz Schulze says that "Mies in 1907 was already committed to the classicist temperament that would remain with him for the rest of his life.,20

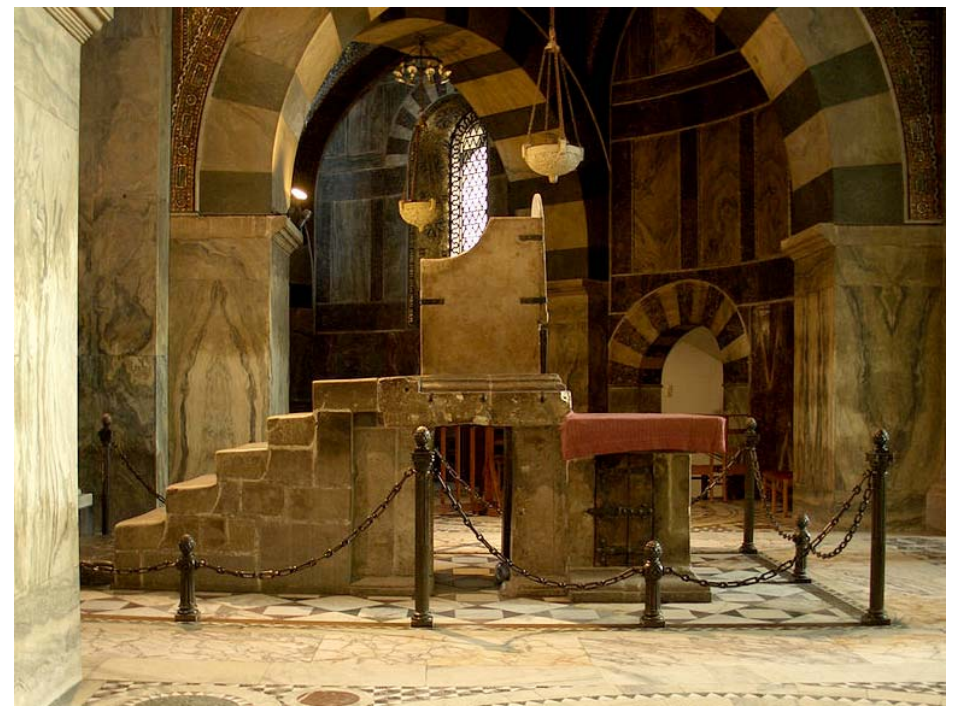

Plate 8. Palatine Chapel, Aachen, Germany, 792-805

In 1908, one of Mies's early clients sent him on a professional pilgrimage to Italy, where he directly encountered the classical architecture that so comprehensively informed his later work. ${ }^{21}$ He visited Vincenza, Florence, and Rome. Years later, he told his grandson about seeing the Palladio Rotondo ${ }^{22}$ and about its influence on his own villas; and about the Palazzo Pitti. ${ }^{23}$ He saw Vitruvius's country houses, and Roman aqueducts, which he praised for their

\footnotetext{
${ }^{19}$ Johnson, Mies van der Rohe, 9.

${ }^{20}$ Schulze, Mies van der Rohe, 28.

${ }^{21}$ Ibid., 23.

${ }^{22}$ A sixteenth-century Renaissance villa, designed by Andrea Palladio, near Vicenza, Italy, based on the Parthenon. The correct name is Villa Almerico-Capra.

${ }^{23}$ Florence, Italy. Mies called it "one of the strongest buildings...just huge stone walls with windows cut out... with how few means you can make architecture.” Schulze, Mies van der Rohe, 30.
} 
generalizing simplicity. A generalized simplicity, or universal paring down of elements, was to become a trademark of Mies’s work.

From 1908 to 1912, Mies worked with the early German industrial designer Peter Behrens. From Behrens, he learned particular appreciation for principled design and fine detail, ${ }^{24}$ qualities to which Mies seems to have been naturally predisposed. These qualities, combined with Mies's appreciation for precision and thoroughness, made it possible for him to work successfully within a modern, industrial mindset to realize a classically-inspired aesthetic ideal. Equipped with a rich background of education and training, he was able to develop a distinctive approach to the idea of perfection in the context of the new challenges and possibilities occasioned by the development of twentieth-century building materials. He was able to use his appreciation for detail and fine materials to transform an ancient style of architecture into a refined system of design suited to the regularity and precision of mass production.

One of the central problems of architecture for Mies lay in achieving a relationship between the aesthetic and the material. He grew up admiring the beautiful handiwork of centuries of stone masons. Still, Mies understood that technological progress was increasingly placing that style and quality of craftsmanship out of the financial reach of most people. Machines could produce building materials more cheaply, more quickly, and in much larger quantity.

As I was born in an old family of stonemasons, I am very familiar with hand craftsmanship.... My receptiveness to the beauty of handwork does not prevent me from recognizing that handicrafts as a form of economic production are lost. The few real craftsmen in Germany are rarities whose work can be acquired only by very rich people.... Our needs have assumed such proportions that they can no longer be met by methods of craftsmanship. ${ }^{25}$

\footnotetext{
${ }^{24}$ Johnson, Mies van der Rohe, 12.

${ }^{25}$ Beatriz Colomina, "Mies Not," in The Presence of Mies, ed. Detlef Mertins (New York: Princeton Architectural Press, 1994), 204.
} 
Conversely, Mies recognized the potential, both practical and aesthetic, in the new materials. What better way to achieve perfect measurement, symmetry, and order than by the use of the machine to produce materials more perfect than any craftsman could make, or possibly even dream of making, by hand? New technology, such as precision tools and manufacturing processes, made it possible for architects to focus more carefully on questions of measurement, regularity, and clarity. The very nature of the machine made precise measurement possible, allowing for even more meticulous symmetry and balance. The development of steel and glass as building materials allowed Mies to surpass his predecessors in his quest for geometric perfection, that ancient central design element. Although he did not express a desire to measure his work against the classical golden section, ${ }^{26}$ Mies clearly was looking for proportions and materials that would result in elegantly-built, visually-balanced buildings. He employed regularity, repetition, right angles, and straight edges to create an architecture adaptable in size and shape but universal in its application. Perhaps for this reason, it is Mies's work, among the Modernists, that is the most accessible or readable as a reinvention of classical ideas in modern terms. It is, in fact, the legacy of his work that came to be associated with the concept of the modern classical and, thereby, the standard for mid twentieth-century architectural design and building.

For Mies, classical ideals established the formal and ideological basis of his work. In this orientation, he certainly was not alone. Other Modern architects also turned to the classical in varying degrees. Le Corbusier (1887-1965), as is well known, based much of his early work onthe Acropolis in Athens. ${ }^{27}$ His extensive writing on the Parthenon influenced his contemporaries, as did his emphasis on the machine as a model for "clean” living.

\footnotetext{
${ }^{26}$ The golden section is a ratio based on pi that the Greeks, among others, are said to have used to achieve beauty in their architecture.

${ }^{27}$ As a young man, Le Corbusier visited and documented the Acropolis. See Le Corbusier, Vers une architecture (Paris: Edition Crès, 1923). The experience continued to influence both his building and writing throughout his career.
} 
While Le Corbusier's work explored new, freer forms based on his modular system, Mies was strongly committed to a consistent, clear, classical vision. For him, these classical values of symmetry and proportion were completely essential. One could say he took these elements to the extreme. He made them more than mere components of his work; rather, they became the very subject of it. Proportion, symmetry, precision, order, and balance were not just features of his work; they were its conceptual foundation. These intellectual and aesthetic concerns were fitting for an architect who became a leader in the International Style, a movement that emphasized technological advancement and the transcendent quality of architecture.

As noted above, Peter Behrens (1868-1940), with whom Mies and many of his contemporaries had apprenticed, was the forerunner and inspiration for many the architects of the western modern age. They were influenced by Behrens’s classically-inspired factories, which focused on the fusion of function and design and contained many classical elements. These classical elements were pared down and expressed in a modern style.

In his 1908-09 Berlin A.E.G. Turbine Building (plate 9), Behrens had pioneered the use of elegant line, basic symmetry, and large areas of glass to call attention to the importance of modern industry. He modeled the front of the A.E.G. factory building, for example, on a classical temple, making it the modern equivalent in new materials. The building was raised on a plinth, which was higher and more prominent on the front façade of the building beneath the wall of windows. This higher plinth calls attention to the façade, much the same way steps call attention to the main façade of classical temples. There are regularly-spaced steel structural beams on the side of A.E.G. that serve also as pilasters, similar to the engaged columns on the outside of the cella of the Maison Carree (plate 10) in Nimes, France, 16 B.C.E. A.E.G. also features an updated, rounded pediment with the company name forming a kind of frieze. Just as 
the frieze on the Pantheon in Rome (plate 11), 126 A.D., identifies its builder, ${ }^{28}$ Behrens' frieze identifies the name of the company for whom the building was constructed. Behrens' use of these updates features is a direct translation, from ancient to modern, of a well-established set of classical elements.

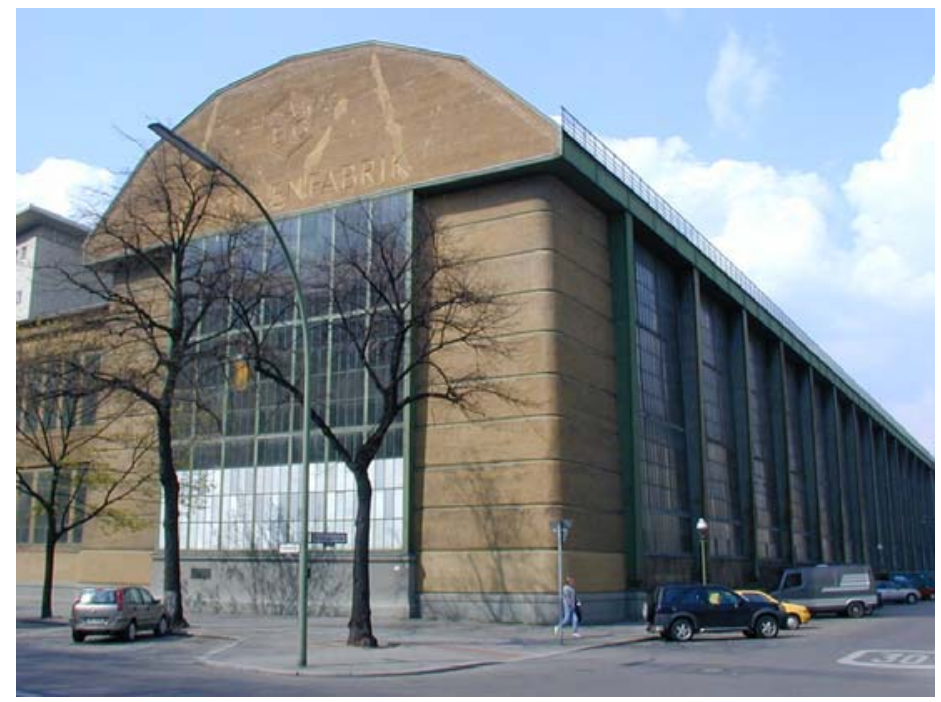

Plate 9. Peter Behrens, A.E.G. Turbine Factory, Berlin, Germany, 1908-09

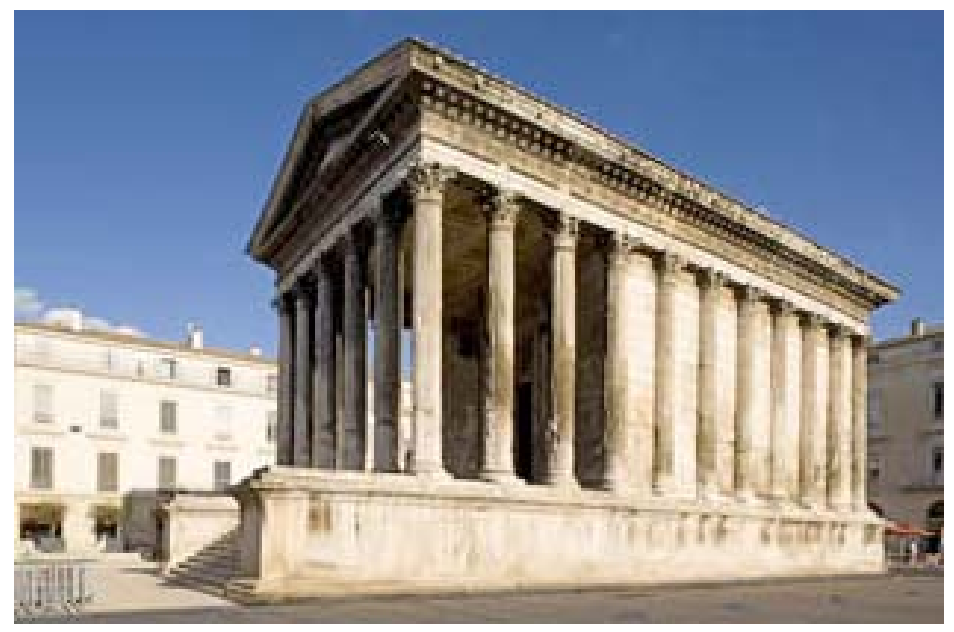

Plate 10. Maison Carree, Nimes, France, 16 B.C.E.

\footnotetext{
${ }^{20}$ Frieze translates as "Marcus Agrippa, the son of Lucas, three times consul, built this.”
} 


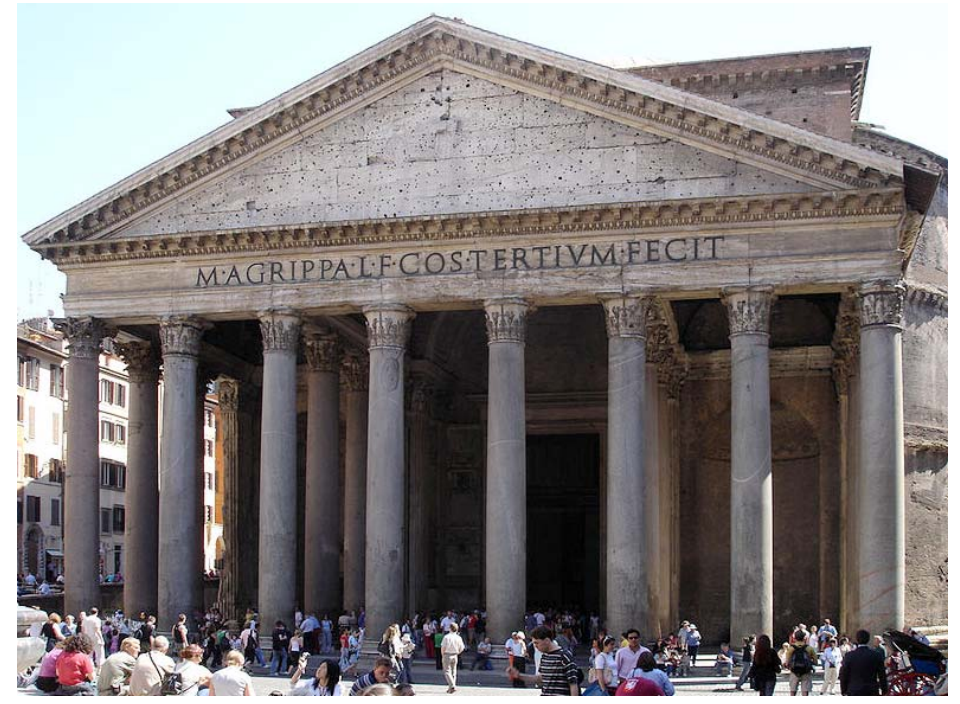

Plate 11. Pantheon, Rome, Italy, 126 A.D. (Photo by Martin Olsson)

Having worked under Behrens, Mies continued to explore issues of classical interpretation in his own work. His German contemporaries, most notably Walter Gropius, joined him in this exploration. Gropius (1883-1969) further developed the "factory aesthetic," particularly in his 1910 Fagus Shoe Factory (plate 12), designed with Adolf Meyer in Alfeld, Germany, and his Dessau Bauhaus buildings of 1925-26 (plate 13). In the Fagus building, he expanded on Behrens’s gridded design, transforming the windows into thin, light "walls” all around, punctuated by inset vertical piers of bricks set at regular intervals between sets of windows, reminiscent of the engaged columns of classical temples (plate 10). He incorporated the raised entrance, this time made of brick, into the design of the building, a reversal of Behrens's windows surrounded by brick. Also, the extension of the windows around the corners of the building recall the way light enters the openings between columns in that surround many classical buildings. The horizontal bands of darker brick on the entrance recall Roman wall construction, or opus reticulatum. $^{29}$ Graves.

\footnotetext{
${ }^{29}$ This wall construction will be discussed more in the chapter on the Erickson Alumni Center of Michael
} 


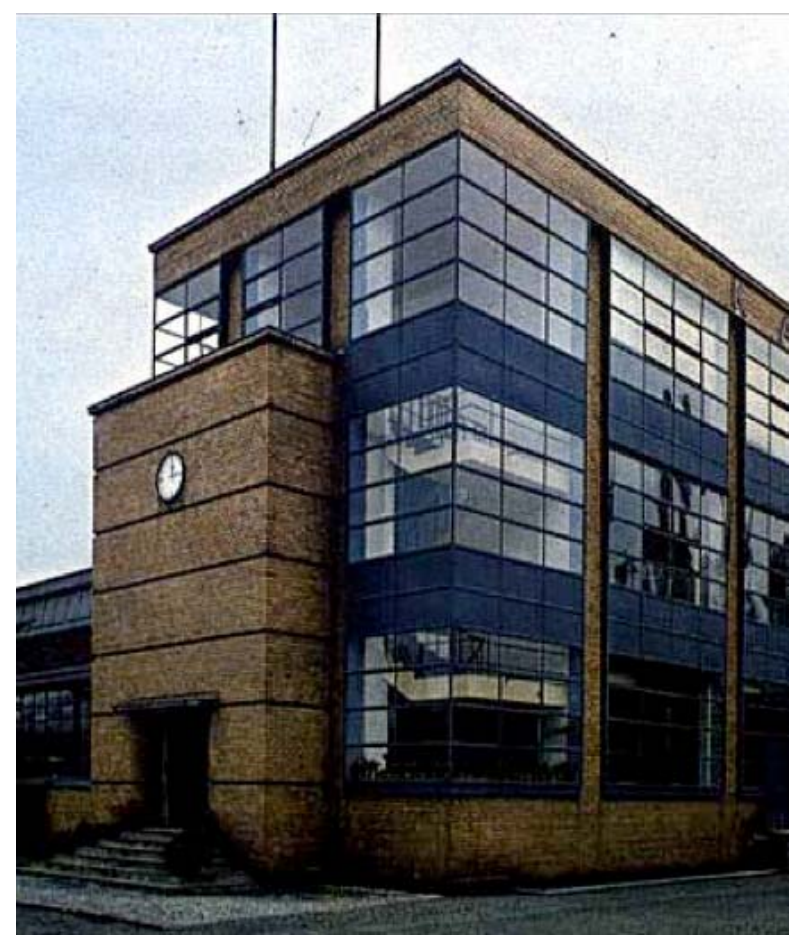

Plate 12. Walter Gropius with Adolf Meyer, Fagus Shoe Factory, Alfeld, Germany, 1911

Gropius further developed his concept of the factory aesthetic in his Dessau Bauhaus, an institution for which first he, and later Mies, served as directors. This building, with its curtain wall of windows exposing the underlying structural grid, presaged Mies's beautifully-articulated buildings featuring the structural grid as the foundation for their design.



Plate 13. Gropius, Bauhaus, Dessau, Germany, 1925-26 
Mies transformed the new factory aesthetic into a celebration of the machine and its direct impact on building design and production. He turned the focus away from the function of the factory and placed it directly on the materials the factory made possible. He used these materials to express his own modern interpretation of classical ideals.

Mies recognized that buildings often outlast their original function and therefore should have a universal design, not one tied forever to a specific function or location. Realizing the modern potential for even more rapid improvement through new technology, he recognized that function would "change with increasing frequency in the modern world. ${ }^{30}$ Buildings would last even longer and should be designed to accommodate whatever the future brought. Architecture truly was transcending its original specific use. Mies’s focus on the machine, on technology, became a focus on the expression of ideas in materials that spoke to the new capabilities of his age. The beauty of this new technological age lay in its ability to allow artists to produce universal works of art based on a set of precise standards. Mies hoped these standards would allow for an architecture that would transcend time and place, as classical architecture had done. He saw the spiritual, as well as the material, potential in architecture. As classical building had transcended time, so could its modern reinterpretation. Architectural historian Peter Blake stated The only function one could be sure of in any building built to last was the function of flexibility of use throughout its lifetime [author's emphasis]. So, the only kind of building which would make sense, in terms of functionalism, would be a building not adjusted to any specific function at all! The concept of the "universal building" probably came to Mies out of his knowledge of Karl Friedrich Schinkel and the classical tradition. The greatest contribution the classicists had made to our civilization - from the Parthenon to the Greek Revival - was the idea of universality. They believed that mankind needed not special but universal [author's emphases] solutions - solutions as applicable to a temple as they might be to a palace.... What Mies did...was to take the classical notion of universality and translate it into steel, brick, and glass. ${ }^{31}$

\footnotetext{
${ }^{30}$ Blake, Master Builders, 236.

${ }^{31}$ Ibid., 236. On page 237, there is an interesting response to the idea of universality in building from one of Mies's friends, a businessman: "Do you realize what this means? Don't you know that the entire economic system of the U. S. is based upon the rapid obsolescence of our buildings, cars, consumer goods? If buildings were
} 
Along with Gropius and other Bauhaus artists of the 1920s and '30s, Mies pursued the integration of aesthetics and engineering into a comprehensive approach to the architectural arts. He fused the intellectual but ultimately disembodied beauty of pure design with the tangible physical qualities of the new industrial materials. Mies did not subjugate the technical aspects of building to appearances but found a way to integrate the two in a grand celebration of the modern and the classical. Through these means, he sought to establish an architecture that would transcend political boundaries and personal aesthetics to become something more universal. He developed a consistent architectural system based on geometry and proportion and used newly developed technology to perfect his system. By employing the most advanced materials as both structure and "decoration” (as in his 1930 Tugendhat House in the Czech Republic), he glorified the Machine Age as an "Age of Man” and attempted to transcend the banalities of everyday existence in an increasingly alienated, modern society.

Mies rendered invisible the material conditions of technology, industry, and labor by rewriting or reworking them and making them an 'ornamental' pattern that would redeem technical structure by transforming the calculus of means and ends into the evocation of an end in itself. ${ }^{32}$

Just as the architecture of ancient Greece and Rome generally has been accepted as the foundation of western building, so classical philosophy and political systems formed the basis of what westerners consider “civilization.” Westerners searching for contemporary purpose and meaning often have turned to these sources for guidance and inspiration. So, Modern architects turned to classical models for relevant points of reference. The ancient classical architectural vision was a universal one. Merely to replicate that vision by pure imitation would have been to

designed with so much flexibility that they would never wear out - well, that would wreck our whole building industry!" It is cited that this common view among Americans fueled criticism of Mies. Not until the 1950s did Americans begin to see that the need for more shelter made Mies's idea of universality sensible.

${ }^{32}$ Detlef Mertins, "Mies’s Skyscraper "Project": Towards the Redemption of Technical Structure," in The Presence of Mies, ed. Detlef Mertins (New York: Princeton Architectural Press, 1994), 66. 
create works of art that were anachronistic or sentimental. Modern architects instead sought to redefine the underlying classical aesthetic principles in terms that expressed their own age, with their own problems and challenges. Classicism, therefore, provided a monumental foundation for the investigation of the potential of the human spirit for which modern architects were searching.

Despite functionalist and determinist rhetoric, most masters of the Modern Movement were deeply interested in tradition. They sought not the banishment of history (as is often said), but its reevaluation at the level of fundamentals; they rejected the superficial manipulation of the style and embraced the quality of style in general which they perceived, in terms of abstract formal structures and patterns rather than on terms of specific grammatical usages. The attitude to tradition was "radical since it embraced drastic innovation and the return to the roots simultaneously. ${ }^{33}$

In Mies’s 1922 proposed (but never built) German Office Building (plate 14), already present are the revealed structural columns that would be so common to his later work. In this early example, though, the columns are made of concrete. In this structure, Mies employed the classical regularity of the column in the entryway and the colonnade at ground level. He accentuated the classical reference by giving the building the appearance of being raised on a or plinth, forcing a procession up a central set of steps. Like Sullivan’s Guaranty Building, Mies’s office building recalls a classical column: the plinth as a base, the main part of the building the shaft, and the roof extending slightly over the sides of the building like a capital. (Mies’s building is horizontal, though, rather than vertical.) This design prefigured Mies's later work in its open presentation of the function and use of materials.

\footnotetext{
${ }^{33}$ William Curtis, “Modern Transformations of Classicism,” Architectural Review, 176 (August 1984), 40.
} 


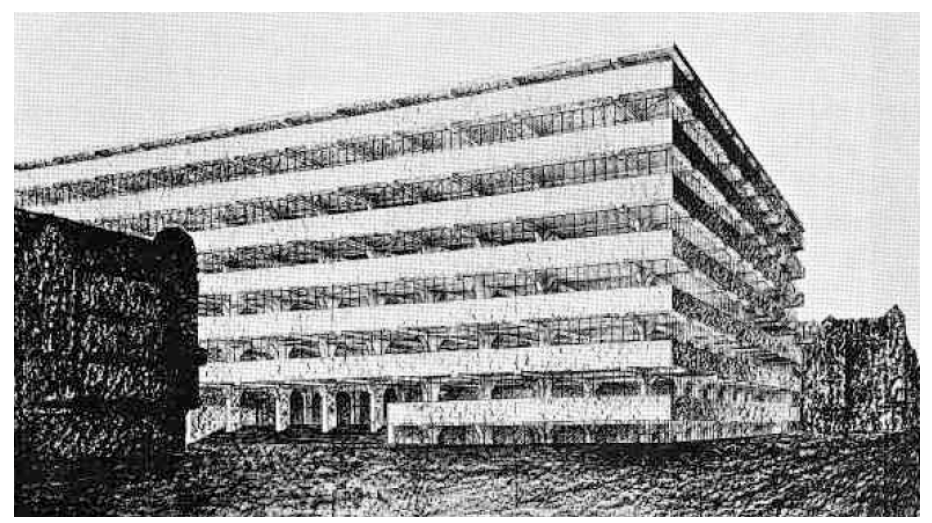

Plate 14. Mies van der Rohe, Proposed Office Building, 1922

With his 1928 unbuilt Adam Building in Berlin (plate 15), Mies’s style moved further toward what was to come on his later work. Its steel beam pilotis (thin structural supports derived from the classical column), colonnade, and emphasis on horizontal repetition, are based on classical elements, but their expression here in steel and glass transforms them into a tribute to modern manufacturing.

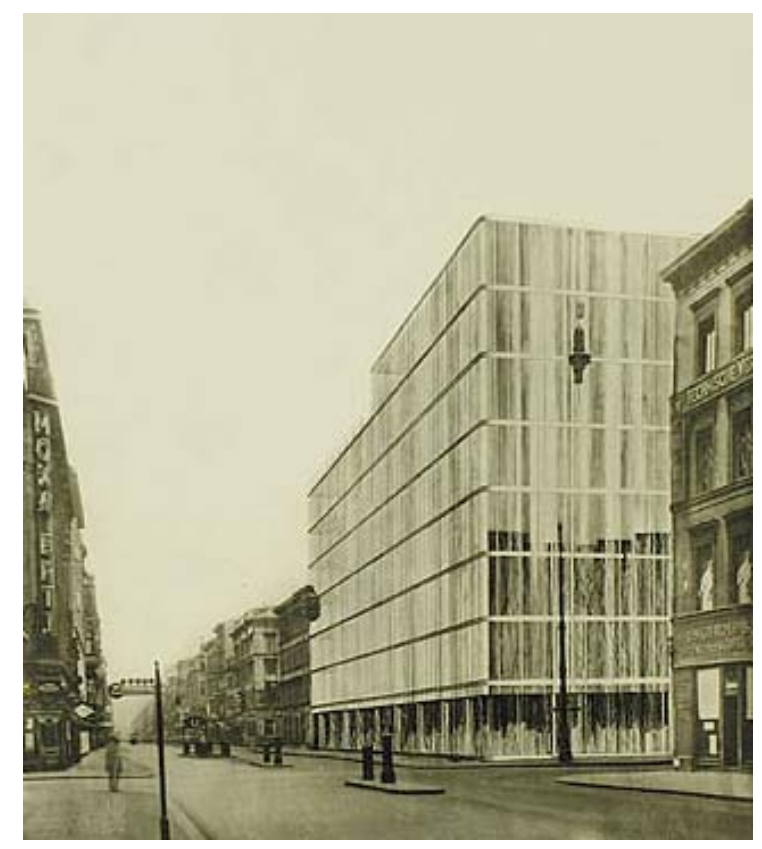

Plate 15. Mies, Proposed Adam Building, Berlin, Germany, 1928

These two early Mies designs illustrate his development of the classical element in modern materials. The noted critic Ludwig Hilberseimer recognized the strong classical influence on 
these works: “[The Adam Building’s] refinement and Ionic elegance [thin, light columns] contrast sharply with the Doric strength and sturdiness [thick, stout columns] of the Office Building in reinforced concrete. ${ }^{34}$ Mies moved through the various classical orders, in this progression from heavier to lighter materials.

The 1945-50 Farnsworth House in Plano, Illinois (plate 16), is possibly Mies’s most elegant and simply stated structure, his most fundamental expression of the classical temple in modern materials. Its solemn simplicity of color and line, its carefully controlled procession (stylobate) up to the entrance, and its elegantly-spaced columns or pilotis, most clearly demonstrates the undeniable classical influence on his work. This house is, in essence, a pure white temple, standing alone in the midst of a beautiful natural setting. It hovers over a raised plinth and is supported by pilotis, made from steel I-beams (painted white in this case), which would become Mies's signature feature. The house is an almost perfectly proportioned and balanced form, a small-scale illustration of his larger works. The human scale reflects the building's function as a domicile and adds to its sense of reductive perfection. Through its more intimate scale, it also harks back to the importance of the human body in classical work.

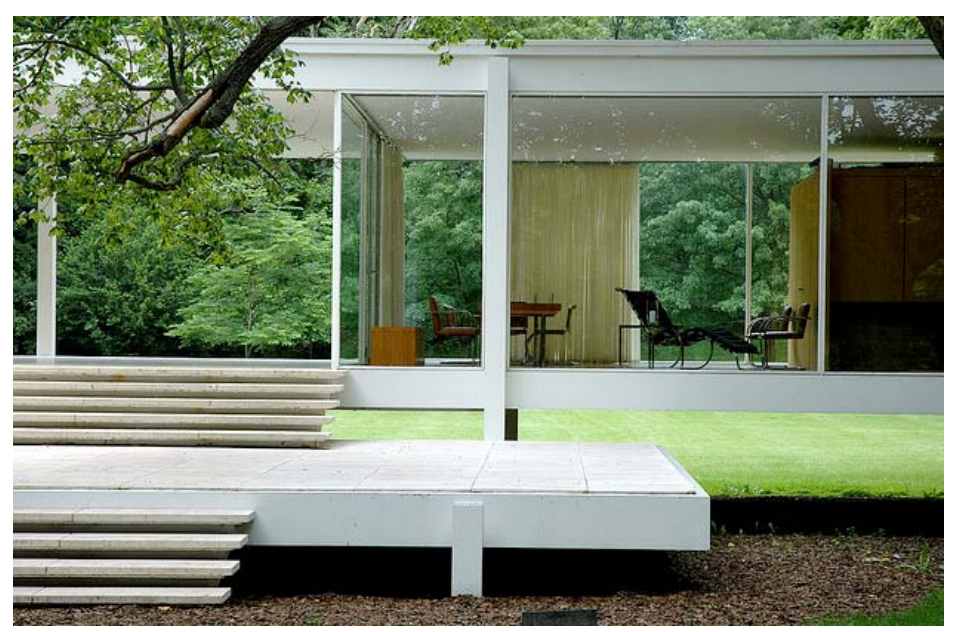

Plate 16. Mies, Farnsworth House, Plano, Illinois, 1945-50

${ }^{34}$ L. Hilberseimer, Mies van der Rohe (Chicago: Paul Theobold and Company, 1956), 28. 
Mies’s Mellon Hall of Science, began a decade later, is a representative example of his mature relationship to classicism. 


\section{Richard King Mellon Hall of Science}

Duquesne University’s Richard King Mellon Hall of Science (1962-68) in Pittsburgh, Pennsylvania (plate 17), is a mature example of Mies’s controlled interpretation of classical ideals in modern materials, of his search for a modern translation of the classical quest for perfection. In this building, one can see Mies's complete immersion in the classical ideals of proportion and symmetry. Constructed of steel and glass, the building exemplifies his concern with a universal building style based on precise measurement and proportion. It features I-beams both as structural support and as, basically, the only purely decorative element. These I-beams serve as a self-reference, calling attention to their important structural use and symbolizing the replacement of the old stone column with the new steel I-beam.

Mellon Hall is a university science center housing departments of biological sciences, chemistry, physics, and pharmacy. The building contains lecture halls, teaching laboratories, and graduate and faculty laboratories and offices. Mies designed a superstructure with a bolted, fireproof steel frame and exterior materials of graphite-painted steel plates, clear glass, and brick.

The entire building is consistent in its repetition of window bays and I-beams, put together to form a regular grid, which is the underlying design element of his mature work. This late Mies building represents his passionate quest for the high-mindedness of classical building, recreated in terms and materials appropriate to twentieth-century western technology. Mellon Hall represents one of Mies’s elegant solutions, both in design and use of materials, to the challenge of the marriage of classicism and modernism. The building is rarely acknowledged, and it has not been the subject of any scholarship. 


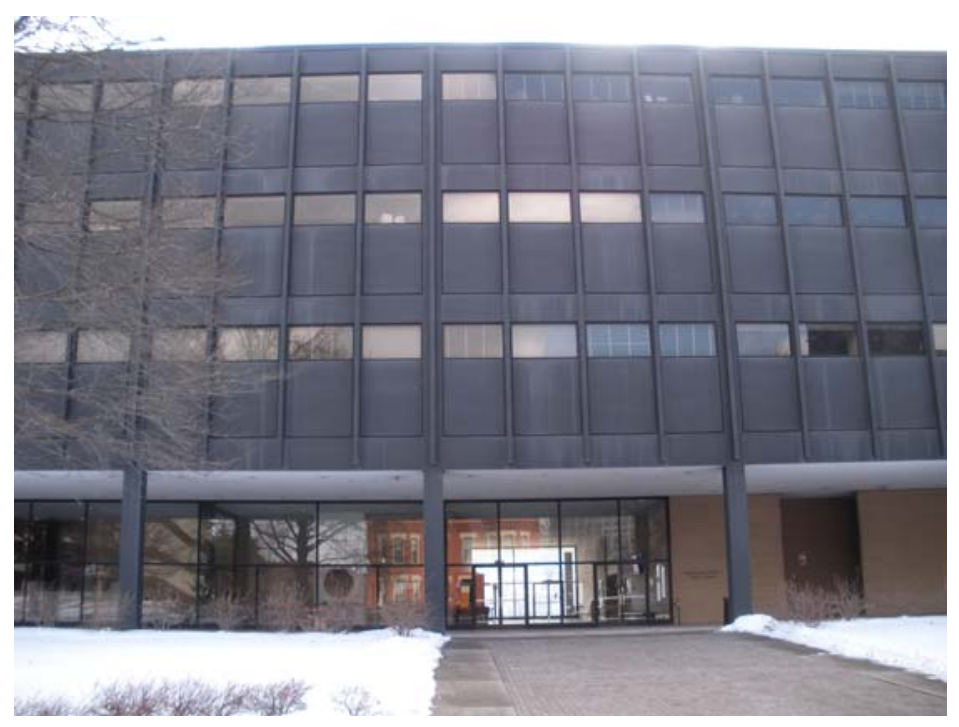

Plate 17. Mies, Richard King Mellon Hall of Science, Pittsburgh, Pennsylvania, 1962-68 (Photo by author)

Duquesne University sought a well-known architect to design a building that would serve as a campus centerpiece and unite the science departments in one structure. ${ }^{35}$ The Richard King Mellon Hall of Science was designed in 1962 and dedicated in 1968 as that centerpiece.

Duquesne is located in a densely built urban setting in downtown Pittsburgh, along a bluff overlooking the Monongahela River. Hills surround the bluff, and, although the Mellon Hall site sits back a little from the edge of the bluff, it is reminiscent of the hilltop sites where ancient Greeks often built their temples (plates 18 \& 19). From the University buildings grouped high on a hill, one can look out over the Monongahela River out to the surrounding hills, where citizens of Pittsburgh live and work. The site is reminiscent of the way the Pantheon sits atop a high hill overlooking the hills of Athens. Both sites literally elevate the visitor above the city, giving the site a feeling of importance.

\footnotetext{
${ }^{35}$ Joseph Rishel, The Spirit that Gives Life (Pittsburgh, PA: Duquesne University Press, 1996).
} 


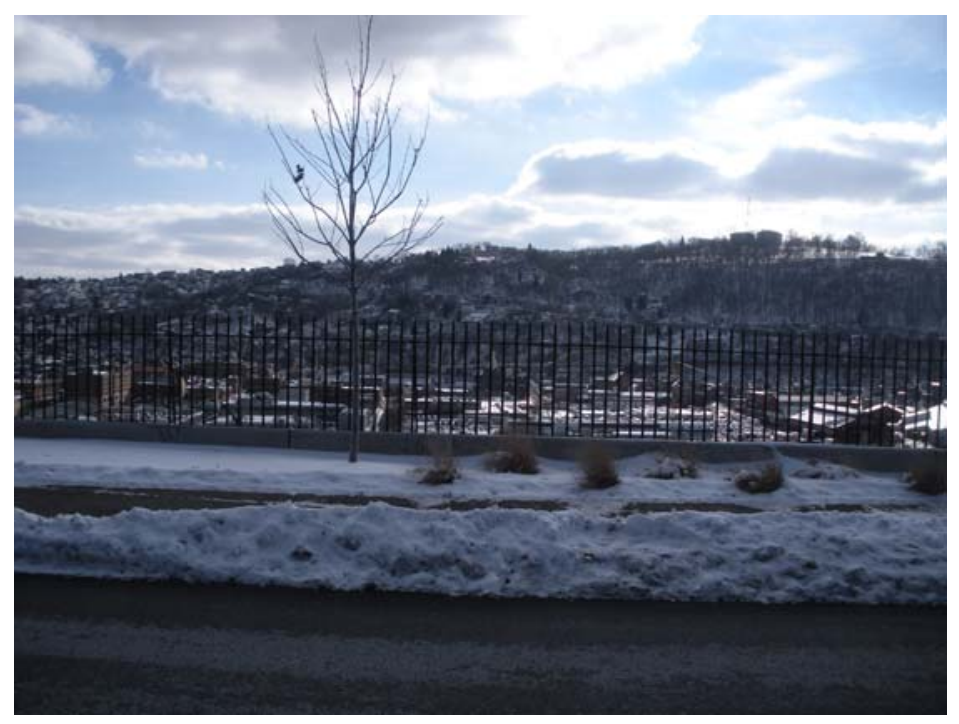

Plate 18. View from Mellon Hall over the hills of Pittsburgh (Photo by author)

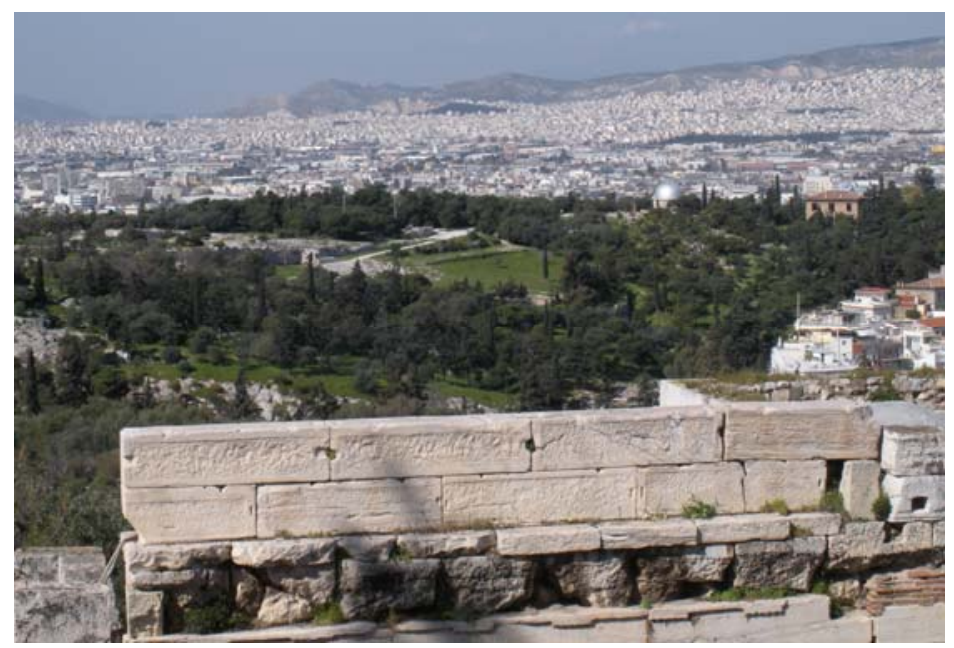

Plate 19. View from Parthenon over the hills of Athens, Greece (Photo by author)

Here, it is appropriate to mention Mies’s debt to Karl Friedrich Schinkel (1781-1841), the nineteenth-century German architect whose influence on Mies is widely known.

When I came as a young man to Berlin and looked around, I was interested in Schinkel because Schinkel was the most important architect in Berlin.... His buildings were an excellent example of Classicism - the best I know. And certainly I became interested in that. I studied him carefully and came under his influence.... I think Schinkel has wonderful construction, excellent proportions, and good detailing. ${ }^{36}$

\footnotetext{
${ }^{36}$ Puente, Conversations with Mies van der Rohe, 31.
} 
Schinkel is credited with having helped Berlin establish itself as an early nineteenth century “Athens on the Spree,” a political state based on the classical Greek idea of free individuals in a free society. ${ }^{37}$ Schinkel's architecture, classical in its severity and geometrical precision, ${ }^{38}$ borrowed heavily from classical Athens (the Parthenon, for example, plate 20), and Mies, in turn, borrowed from Schinkel. Take, for example, Mies’s 1910 entry to a competition for a monument to German Chancellor Bismarck, which sits on a cliff constructed for the building, high above the city. ${ }^{39}$ It is most likely influenced by Schinkel's Altes Museum in Berlin (plate 22), which was influenced, in turn, by Berlin architect Friedrich Gilly’s (1771-1800) painting for a monument to Friedrich the Great ${ }^{40}$ (plate 21).

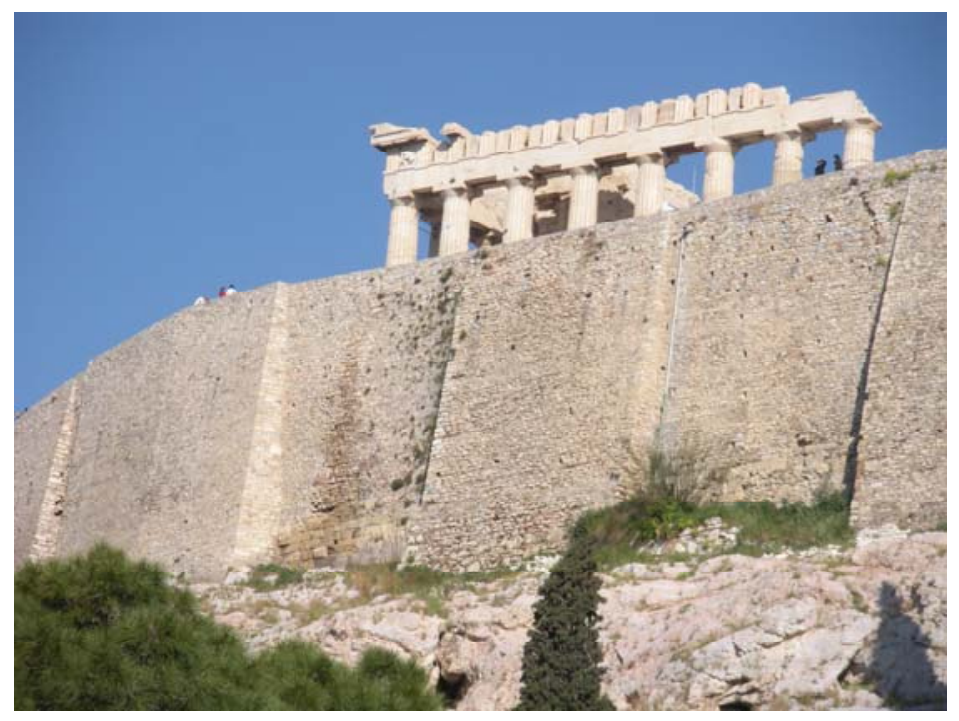

Plate 20. Parthenon, Athens, Greece, 447-438 B.C.E. (Photo by author)

${ }^{37}$ Barry Bergdoll, Karl Friedruch Schinkel: An Architecture for Prussia (New York: Rizzoli, 1994).

${ }^{38}$ Curtis, Modern Architecture Since 1900, 188.

${ }^{39}$ Pittsburgh is a city of hills, like Athens, so Mies had no need to construct a hill, as Gilly would have in flat Berlin.

${ }^{40}$ Gilly was Schinkel's teacher. 




Plate 21. Friedrich Gilly's plan for a monument to Frederick II of Prussia, Berlin, 1797

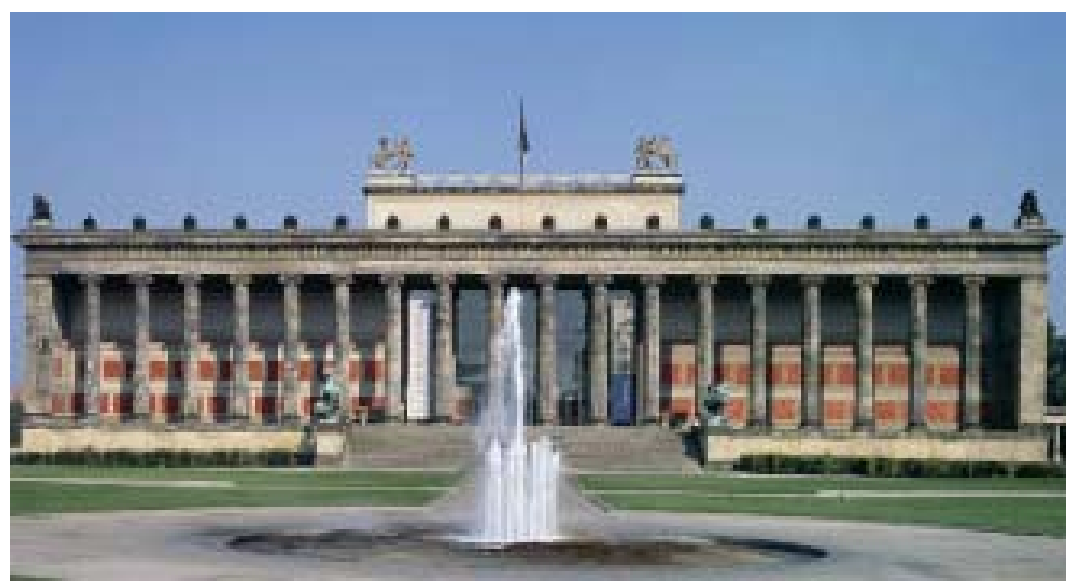

Plate 22. Karl Friedrich Schinkel, Altes Museum, Berlin Germany, 1823-30

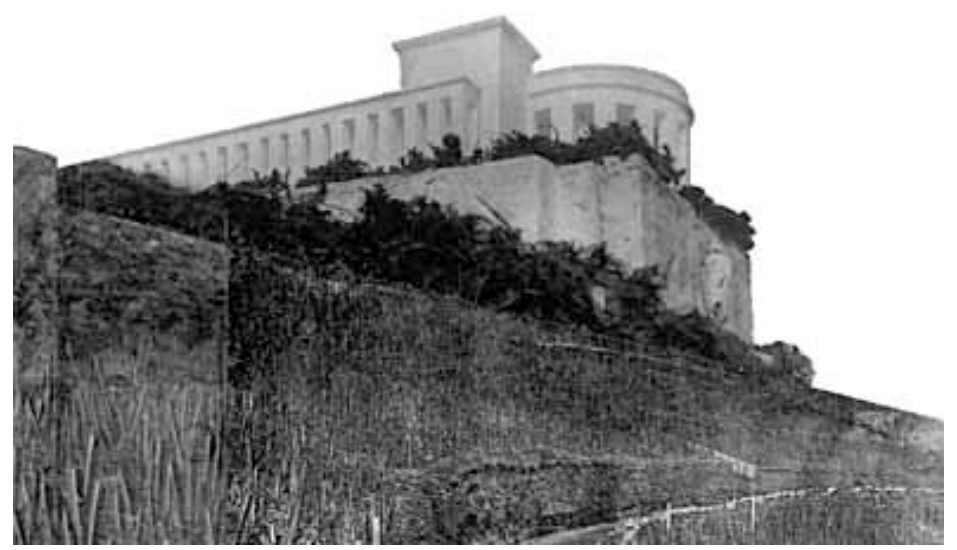

Plate 23. Mies, Proposed Monument to German Chancellor Bismarck, 1910 
Unlike Gilly's and Schinkels's designs, Mies's proposed building contains elements that serve as modern interpretations of classical geometry and regularity. The geometry is simple and bold, the building formed by a rectangle butted against a rotunda (plate 23). Already, we see strong examples of the flat roof and pared down columns or piers. These columns are integral to the design; they act as "walls," defining the periphery of the building. One can easily make the transition to Mies's later works, in which structural as well as decorative I-beams are integrated into the structure. One can see Mies's reinterpretation of the column into a simpler element, devoid of decoration, its structural role given equal emphasis. The column has become part of the building, a sort of pier incorporated into it, rather than standing apart as a supporting element with applied decoration.

Classical influences on Mellon Hall are unmistakable. In fact, they are so important to the building that Mellon Hall could hardly be imagined to exist without them, both structurally and ideologically. The boxy, rectangular building is raised on vertical steel columns that surround the first floor "core" and relate directly to an ancient colonnade (plate 24). Plain steel beams support the structure much the same way classical stone columns did (plate 25). Compare this colonnade to the Parthenon in Athens (plate 26). Both the steel beams in Mellon and the columns on the Parthenon are regularly spaced according to rigorously measured plan. Both lend monumentality to their work and invite the visitor to enter under a protected open area before proceeding into the building. Both are elements demonstrating the strength of their respective contemporary materials. 




Plate 24. Mies, Mellon Hall (Photo by author)

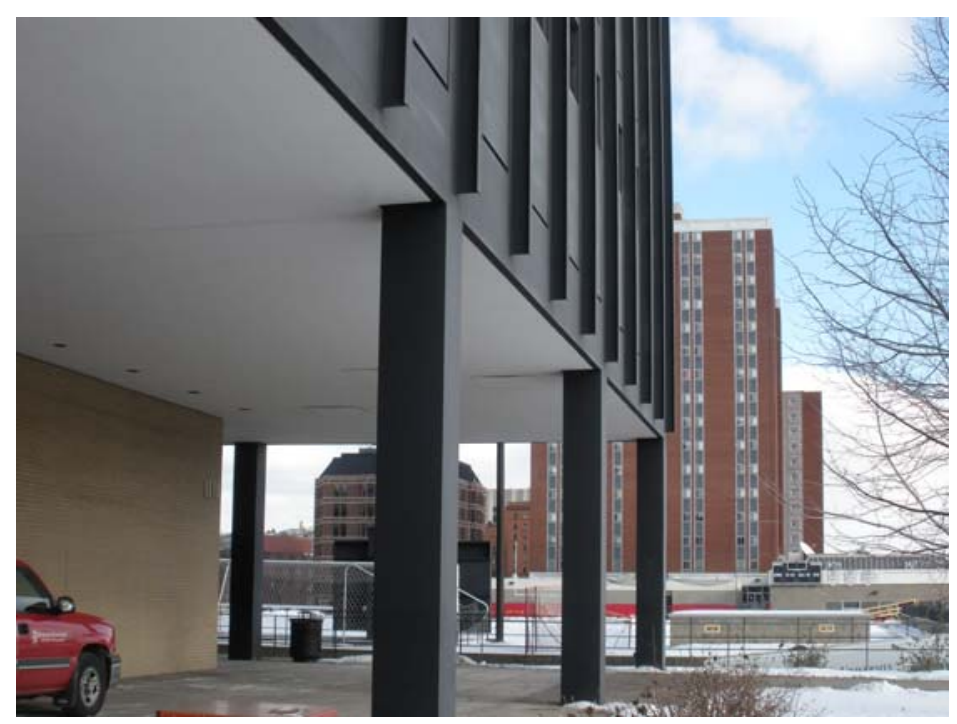

Plate 25. Mies, Mellon Hall colonnade (Photo by author) 


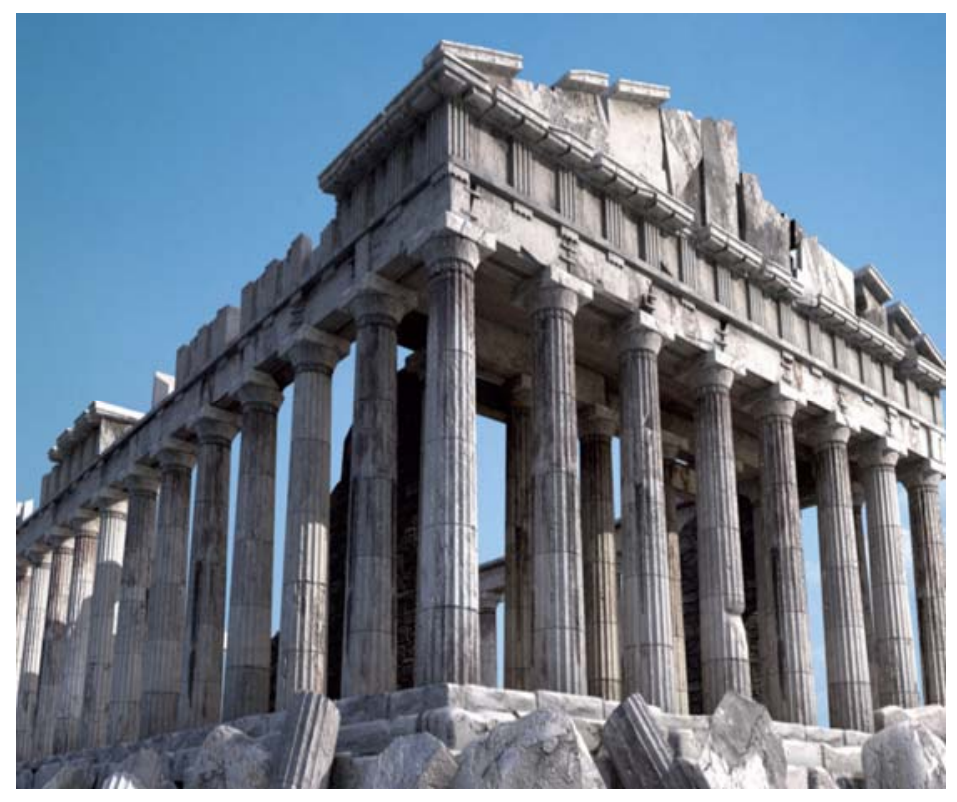

Plate 26. Parthenon colonnade

Mellon’s colonnade runs around the entire building and is formed by regularly spaced, rectangular columns of steel, opposite the building walls of steel and glass (plate 27). The columns are not decorated, except for the graphite paint that covers them. Their regular spacing and placement to form a colonnade refer back to classical architecture. The classical colonnade (in addition to supporting the building) gave it a sense of procession, formality. Consider a comparison with the Stoa of Attalos in Athens, built by Attalos II, ruler of Pergamon, 159 B.C.E.-138 A.D (plate 28). 


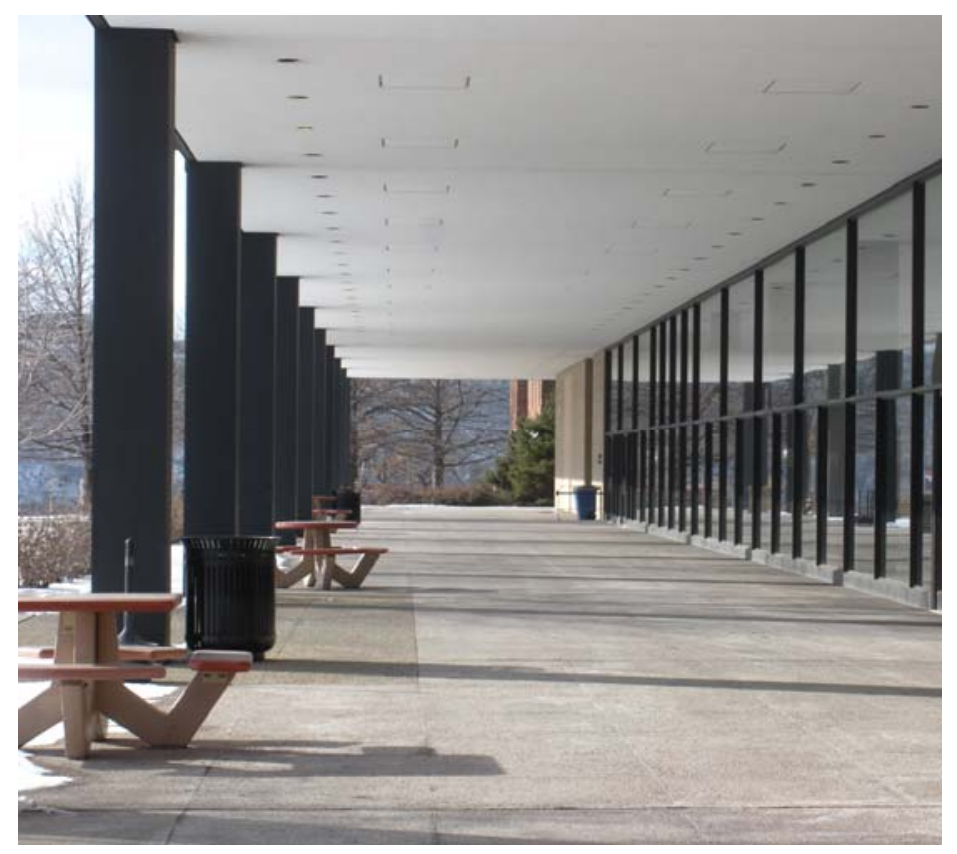

Plate 27. Mies, Mellon Hall colonnade (Photo by author)

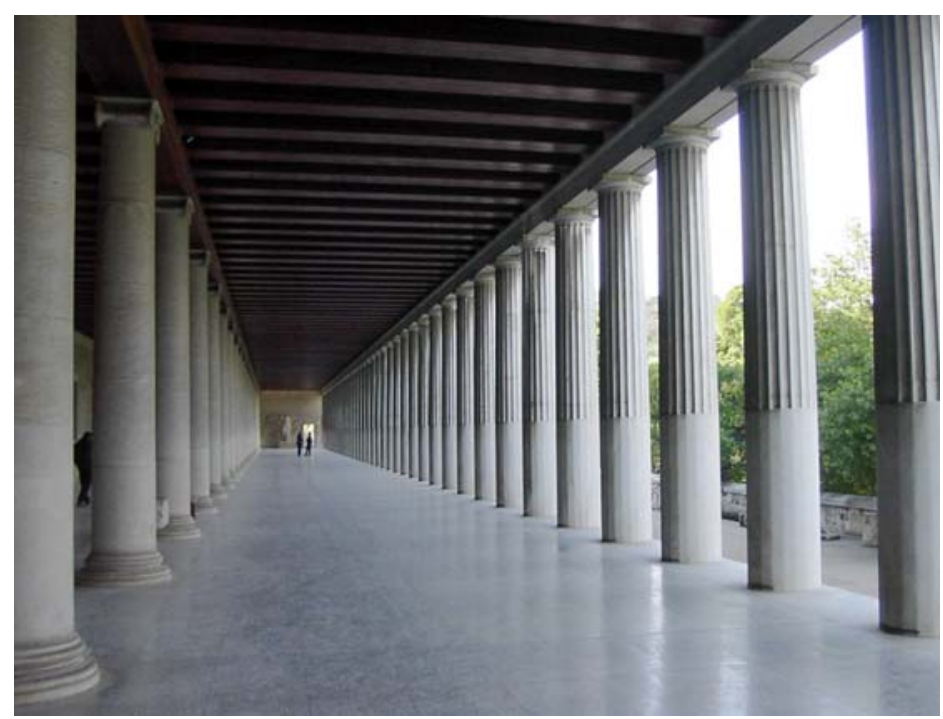

Plate 28. Stoa of Attalos colonnade, Athens, 159 B.C.E.-138 A.D. (Photo by Adam Carr)

Both structures channel the viewer through a protected procession around the building and to and from the entrance. The columns are regularly spaced. Mies's columns, or pilotis, are a key feature of his work and are echoed in I-beams that are applied to the body of the building all 
around. ${ }^{41}$ There is no decoration, as in classical columns of the Stoa of Athens, but this simplicity is consistent with Mies's focus on measurement and proportion, rather than on decoration. There is a subtle reference to a capital where Mies’s columns (or pilotis) join with the ceiling above them (plates $29 \& 30$ ). The simplicity of Mies's columns emphasizes the technological ability to build a column out of one piece of material, rather than by stacking stone drums, as in ancient columns. These stacking of stones can be seen in the Temple of Apollo at Delphi from the seventh century B.C.E (plate 31).

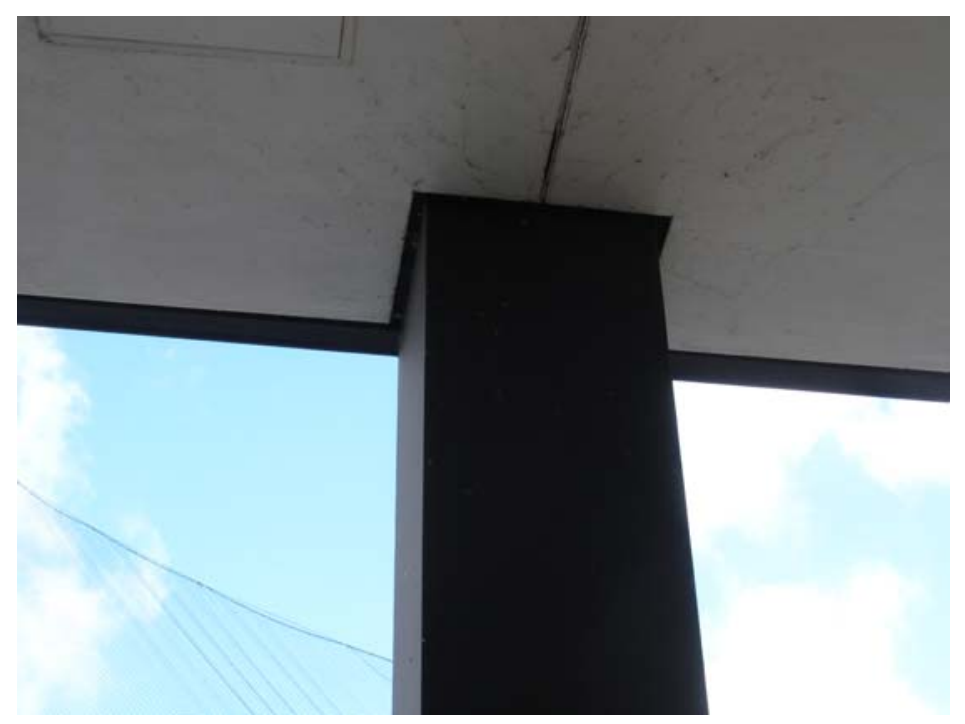

Plate 29. Mies, Mellon Hall steel column or pilotis (Photo by author)

${ }^{41}$ The Swiss-born architect, Le Corbusier (1887-1965), who studied the Parthenon in depth early in his career, used pilotis in his landmark Villa Savoye. This work reflected many classically inspired, especially Greek, influences. Le Corbusier declared pilotis mandatory for all modern buildings. Le Corbusier, Towards an Architecture (London, 1927). 




Plate 30. Mies, Mellon Hall steel column or pilotis (Photo by author)

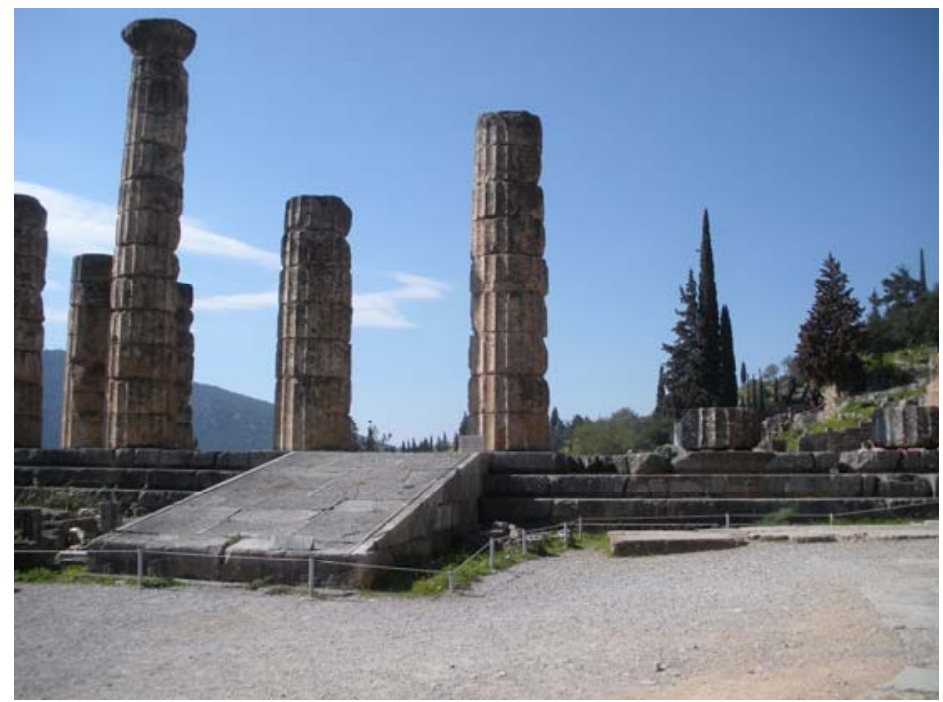

Plate 31. Temple of Apollo column ruins, Delphi, seventh century B.C.E. (Photo by author) 


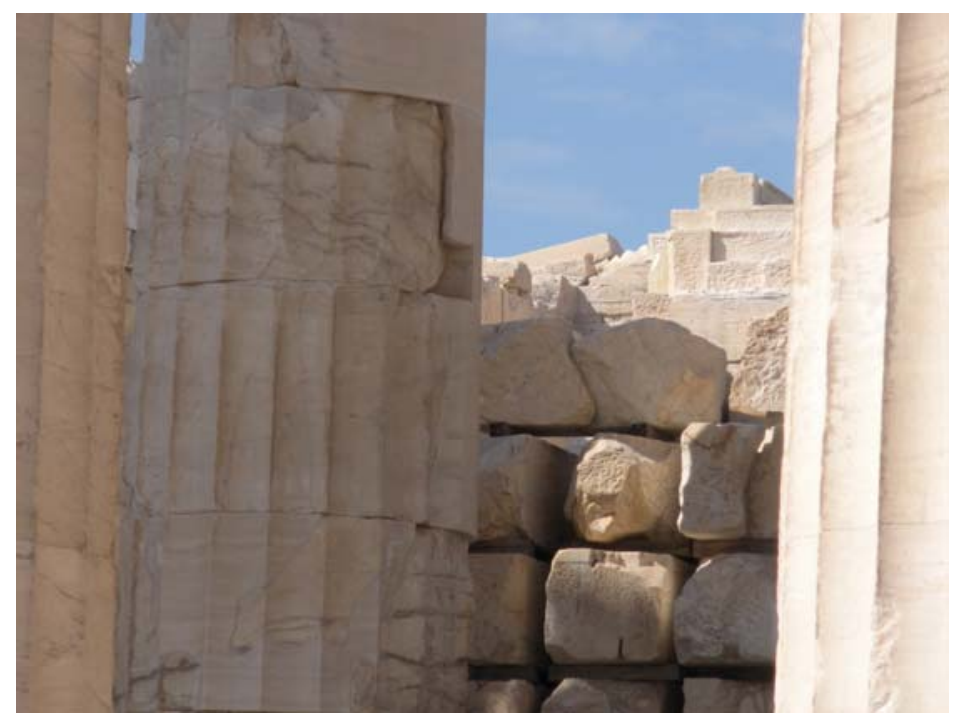

Plate 32. Ruins, Agora, Athens (Photo by author)

Mellon Hall is ordered and rationalist in its simplicity, functional, symmetric, and straightforward in its presentation of the structural materials. (It is, after all, a building for the study of science, not a temple for the worship of gods.) The elegantly-handled materials serve simultaneously as structure and design. As in ancient classical structures, the materials celebrate and showcase building technique. (The Parthenon and other buildings in the Agora in Athens demonstrate advanced classical Greek techniques, plate 32.) Mies’s buildings celebrate the age of glass and steel with an exuberant exposure of these materials.

In fact, all of Mies’ later buildings highlight the use of steel and industrial glass by transforming structural elements_-piers, window bays, and his signature I-beam—into featured elements of the design. Mies combines these elements with a focus on one of the basic aesthetic elements of modern architecture: the grid. Mies suggested that the use of a grid is his buildings is influenced by surrounding streets, ${ }^{42}$ but at other times he mentions the grid as an essential design element. In any case, it seems to be a solution born of the marriage of the classical and the modern, of the regularity of classical proportion expressed in modern structural materials.

\footnotetext{
${ }^{42}$ Puente, Conversations with Mies van der Rohe, 74.
} 
Regularly spaced steel beams naturally create a grid, and Mies was looking for an architectural formula that would suit any building of any use or size. ${ }^{43} \mathrm{~A}$ grid suits this purpose extremely well. In fact, when asked about his placement of buildings standing together, he said the grid suited the relationship between any group of buildings, just as it did within the design on a single building.

There is virtually no ornamentation in the exterior design of Mellon Hall, except for the vertical I-beams that repeat regularly between the window bays. The I-beams appear, at first glance, to play a structural role but turn out to be merely decorative. The beams, representative of the modern, industrial materials that make up the building's structural core, simultaneously act as a symbol of the classical column. They function as virtual pilasters, structural columns attached to walls, rather than standing free, in classical architecture.

The whole exterior of Mellon Hall appears as a regular grid pattern, a matrix of large and small windows. Steel beams are set in evenly-spaced bays. Each bay is subdivided into four seven-foot modules, with each module measuring seven feet in height and consisting of alternating steel panels and fixed rectangular windows (plates $33 \& 34$ ).

\footnotetext{
${ }^{43}$ In many of his writings, Mies discussed his desire to create a universal formulaic structure based on regular measurement using steel and glass.
} 


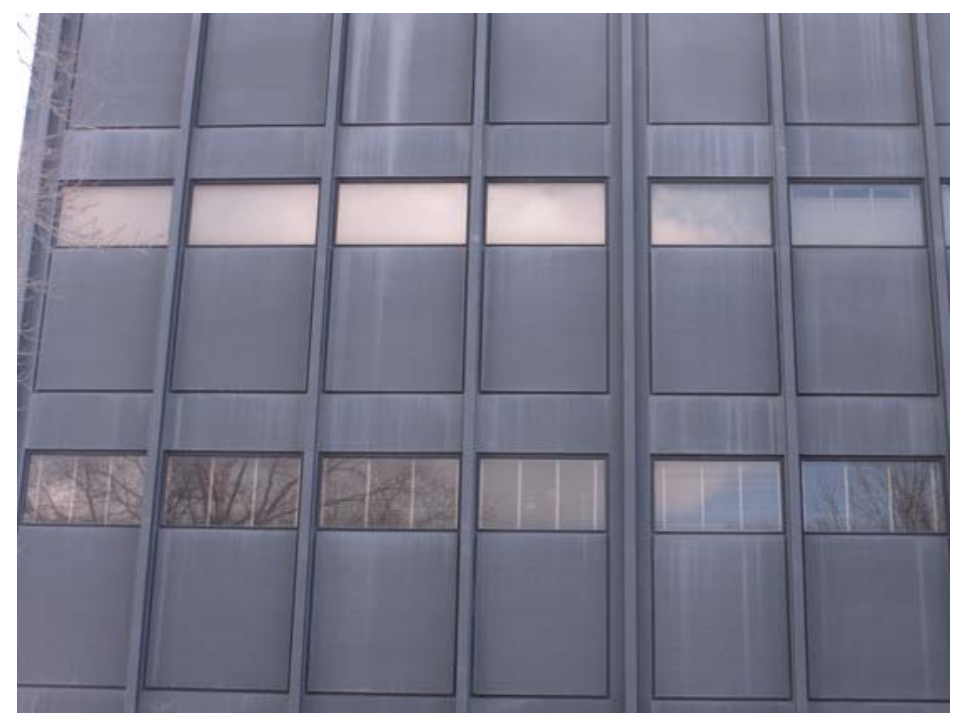

Plate 33. Mies, Mellon Hall repeated window bays (Photo by author)

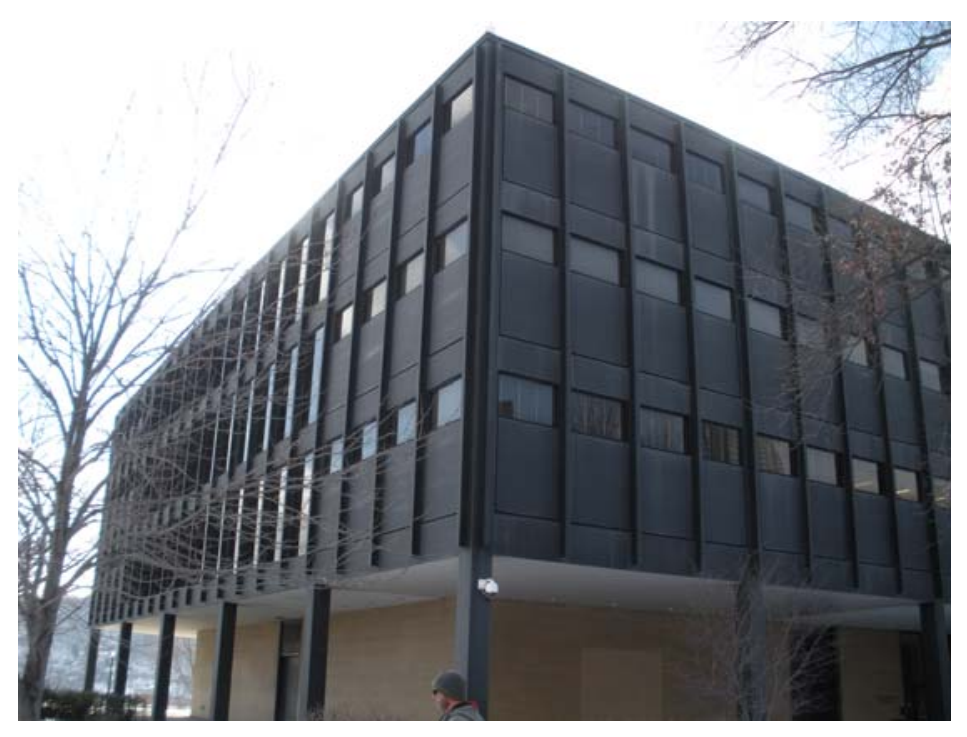

Plate 34. Mies, Mellon Hall grid design (Photo by author)

Together with the decorative I-beams, they form a geometric design not unlike the one on the Parthenon, with its metopes and triglyphs, vertical design elements set side-by-side in a repeating horizontal motif (plates 35 \& 36). Thus, both buildings have strong vertical and horizontal lines. As with the ancient Greeks and Romans, precise attention to proportion and detail is a critical feature of this design. While there is no evidence that Mies aimed to make his 
buildings fit the golden mean, ${ }^{44}$ his generalized and strict attention to proportion and detail is apparent in all his work. By standardizing his system of design and basing it on a grid, he was able to imbue his work with a universality that was adaptable within his system. Modern artists' attention to the grid undoubtedly influenced his work, and the grid-as-skeleton was a perfect system for creating the universal architecture that Modern architects sought to create. The technology available to Mies, steel and glass produced and measured by machine, certainly helped him develop a more precise system.

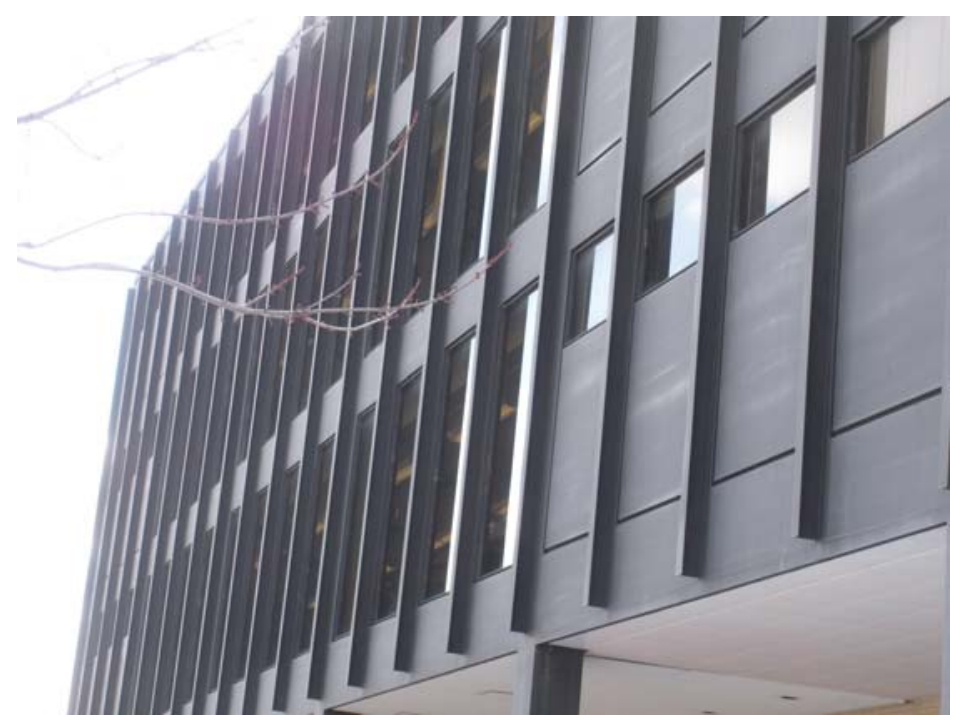

Plate 35. Mies, Mellon Hall decorative I-beams (Photo by author)

${ }^{44}$ See note 25 . 


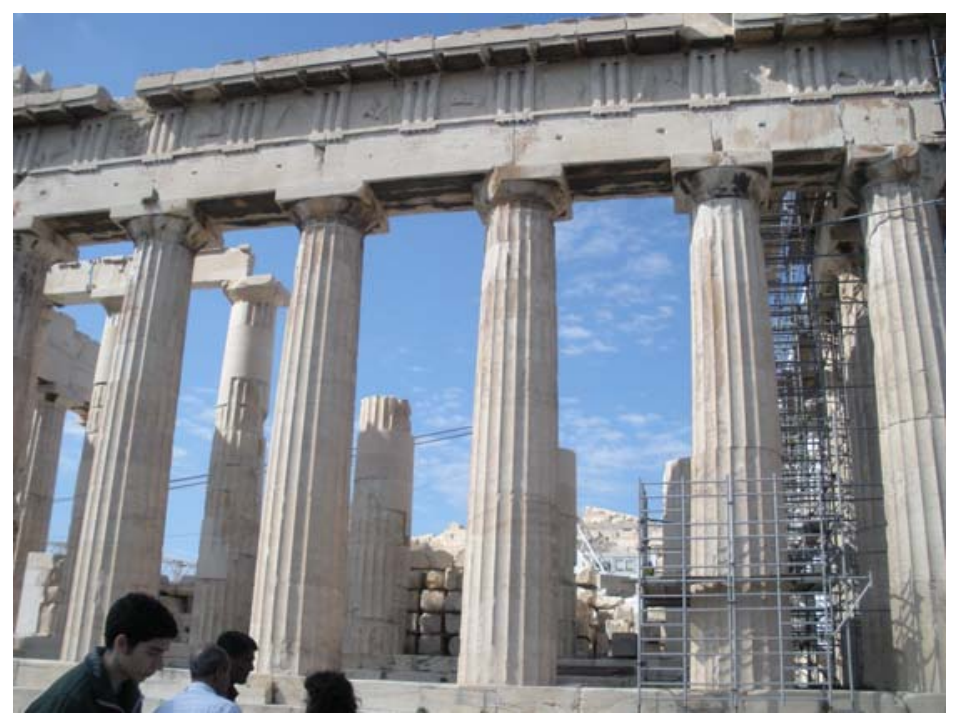

Plate 36. Parthenon architrave with metopes and triglyphs (Photo by author)

It is always the same problem.... It is only in one case you have just, say, walls, and, in this group of buildings, you have buildings to work with. But it is the same problem. You have a good relation among them.... It is the same for a small apartment as it is for a hotel or a bank lobby. There is no difference in these.... The skeleton is just a skeleton. ${ }^{45}$

One of the [International] style's characteristic traits was to express or articulate the structure of buildings externally. It was a style that argued that the functional utility of the building's structural elements when made visible, could supplant a formal decorative articulation; and more honestly converse with the public, than any system of applied ornamentation. A building's structural elements should be visible, Mies thought. The Seagram Building, like virtually all large buildings of the time, was built of a steel frame, from which nonstructural glass walls were hung. Mies would have preferred the steel frame to be visible to all; however, American building codes required that all structural steel be covered in a fireproof material, usually concrete, because improperly protected steel columns or beams may soften and fail in confined fires. Concrete hid the structure of the building — something Mies wanted to avoid at all costs — so Mies used non-structural bronze-toned I-beams to suggest structure

\footnotetext{
${ }^{45}$ Puente, Conversations with Mies van der Rohe, 74.
} 
instead. These are visible from the outside of the building, and run vertically, like mullions, surrounding the large glass windows. This method of construction using an interior reinforced concrete shell to support a larger non-structural edifice has since become commonplace. As designed, the building used 1,500 tons of bronze in its construction. ${ }^{46}$

The flat roofline of Mellon Hall is a modernist convention, as is the use of right angles throughout the building. The interior space is consistent with the exterior grid. It is standardized, regularized, and functional. Mies believed that there were only a few interior designs that worked inside his buildings, with accommodations made for whatever the use of the building at the time. In his writing, he makes a very brief reference to Mellon Hall (not yet named Mellon), and this reference concerns his ideas about his building interiors: "The Science Building for Duquesne University is a laboratory. Since we did not know what would be inside, we thought we would like to let the pipes go wherever they would like to go."${ }^{, 47}$ This seems to be true on the floors used for classrooms and laboratories (photo), but the first floor design is minimal and elegant. The fact that windows form most of the walls of the first floor allow the viewer to see the exterior design of the building, also, from most locations inside (save the inner room that serves as a lecture hall and whose walls are wood). From any place outside the lecture hall, there is a view through the large window-walls of the colonnade with its regularly spaced steel columns.

The openness of the floor plan, however, is rigorously simple and logical, in keeping with Mies's emphasis on rational design. The various interior spaces are arranged so as best to accommodate the modern study of science. The interior as a whole calls to mind the classical temple. The first floor is open in the center, the large space containing a central "chamber," much the way Greek temples contained a cella for religious rites.

\footnotetext{
46 “New Skyscraper on Park Avenue To Be First Sheathed in Bronze; 38-Story House of Seagram Will Use 3,200,000 Pounds of Alloy in Outer Walls Colored for Weathering,” The New York Times (March 2, 1956$)$ : 25.

${ }^{47}$ Puente, Conversations with Mies van der Rohe, 76.
} 
He finished the interior in buff brick walls, oak paneling and doors, plaster ceilings, and rose-black and gray terrazzo floors. As in his 1929 German Pavilion for the Barcelona International Exposition, the materials are richly finished, giving the interior an elegance and serenity common to Mies’s work but uncommon in American university science buildings. Oak and terrazzo lend a quality of polish and grace to the finished interior. The use of exposed structural black steel and large areas of glass give the building an open, modern quality, emphasizing the modern materials with which it was built and the "transparent" approach to construction, featuring, rather than hiding, the structural frame (plate 37-40).

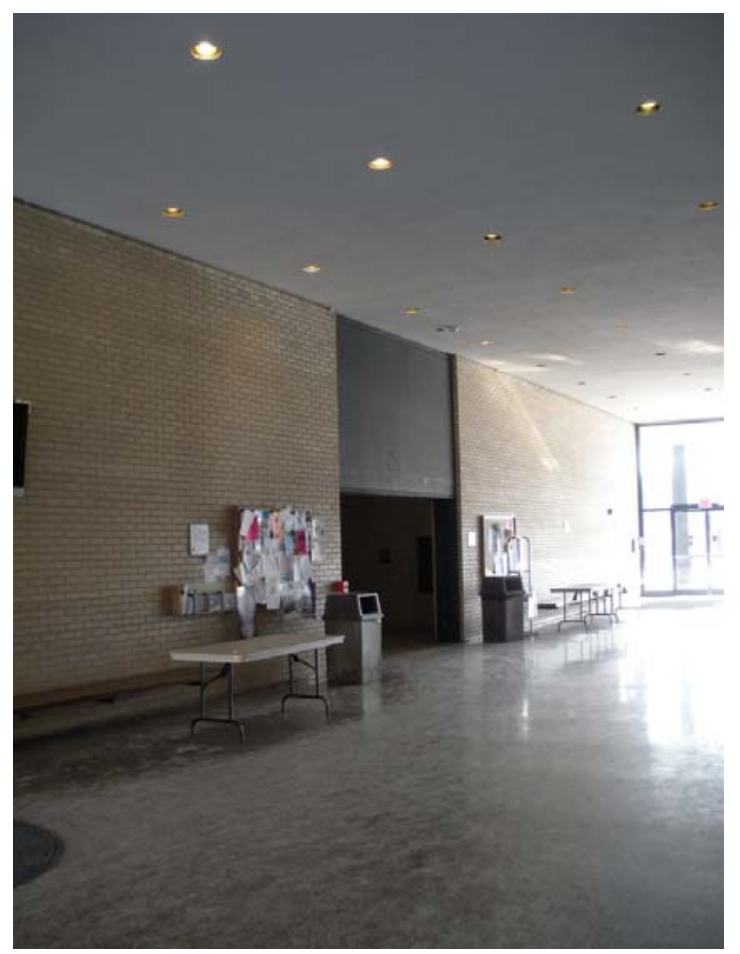

Plate 37. Mies, Mellon Hall first floor lobby (Photo by author) 


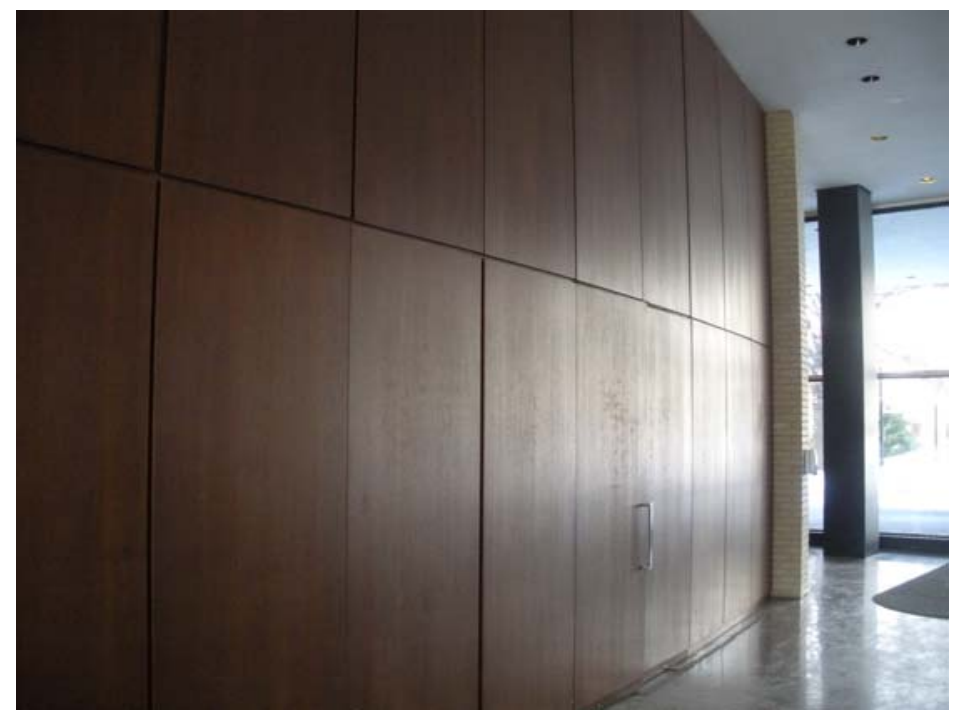

Plate 38. Mies, Mellon Hall first floor lecture hall wall (Photo by author)

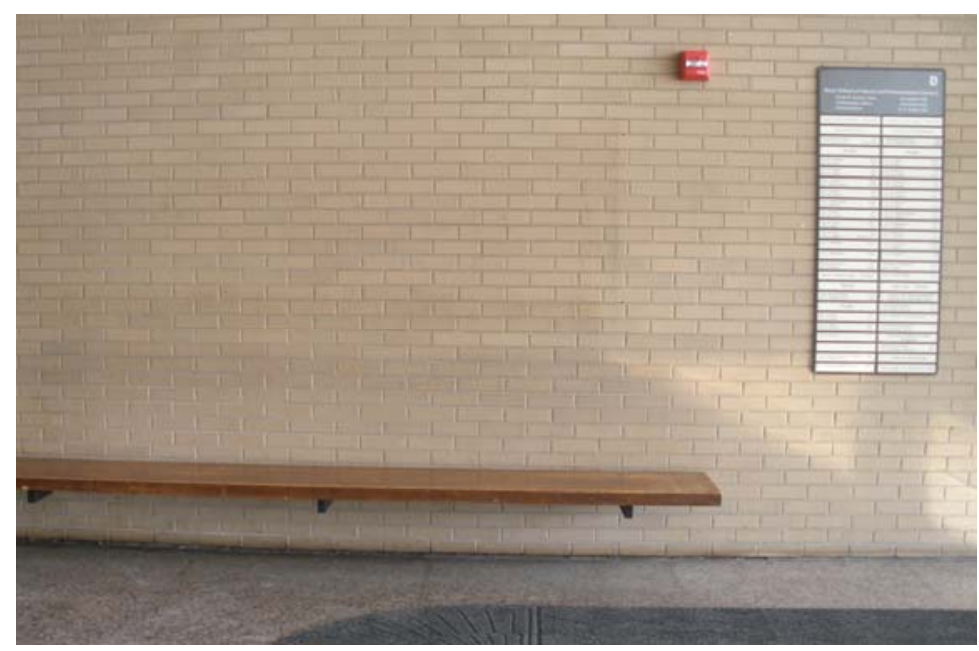

Plate 39. Mies, Mellon Hall first floor Roman brick wall (Photo by author) 


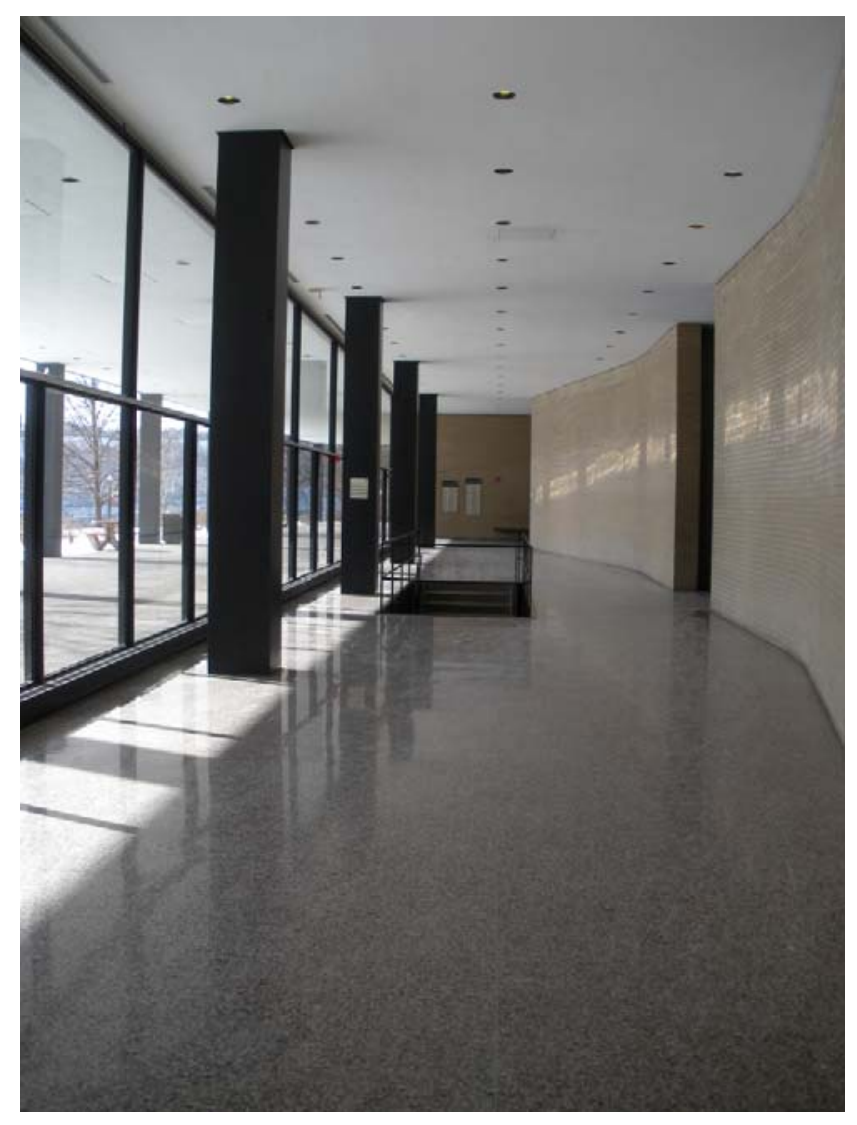

Plate 40. Mies, Mellon Hall first floor lobby (Photo by author)

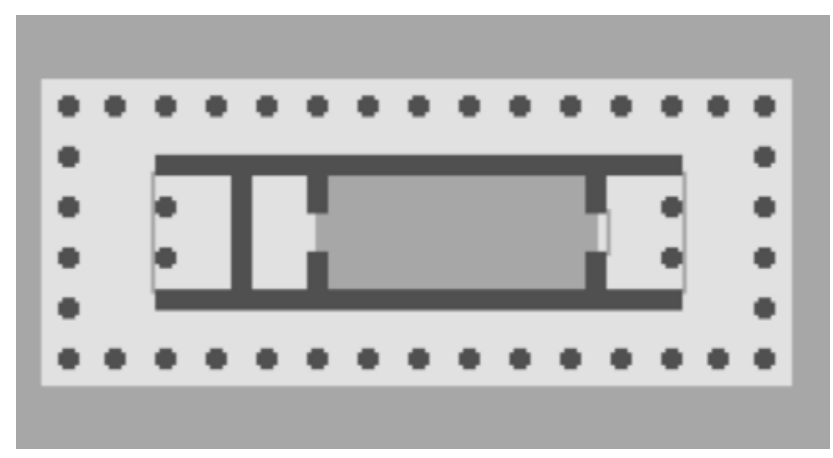

Plate 41. Greek temple floor plan with highlighted cella or inner chamber

The area around this cella is open and allows for easy procession all around, much like the floor plan of a Greek temple (plate 41). The terrazzo floor and the rich wood surfaces give an elegance and importance to the whole lobby. References to the ideals of ancient classical architects are key to this building. There is a spirituality to Mies's work that recalls the spirituality of the classical temple. While the structure itself incorporates many classical 
elements and ideals, Mies’s preoccupation with perfection of proportion borders on the worshipful; however, the rationality of the modern design echoes the rationality of the modern science performed there.

On the upper floors, perimeter areas form one kind of space; interior spaces form another. Except for the ground floor, laboratories and classrooms run around the outer regions, enclosing private offices in the center. The overall plan, though, is a simple, symmetrical, rectangular space. Again, this plan echoes classical temple plans, with a large central open space or cella surrounded by a colonnade. At the ends of the building, there are floor-to-ceiling glass windows. As a classical building might use spaces between columns to provide an opening or view, Mies included these windows to create a connection between interior and exterior space.

Mellon Hall is a monument to exacting measurement, balance, proportion, and scale. He used refined finishing materials inside and out and paid close attention to the richness and variety of their textures and colors. The Greeks and Romans also were careful that the details of their design added to the unified whole. This rational approach to structure and design goes hand-inhand with the pursuit of science: elegant, straightforward, rational. In the Mellon Hall of Science, Mies adapted a classical architectural vocabulary to modern building materials in pursuit of both classical and modern ideals: knowledge, logic, order, perfection, purity, reason, and science. It is a celebratory statement of the potential for good of the human spirit in the age of the machine. 


\section{Michael Graves, Postmodernism, and Classicism}

The work of Mies van der Rohe demonstrates how early twentieth-century Modern architects, most notably those whose work was part of the International Style, based much of their work on classical ideals and elements, which they interpreted in new technological and ideological terms. In the 1960s, the Postmodernists who followed began to react against the Modernist aesthetics in which they were trained. They began to think about classical influences in a different way. Architects such as Robert Venturi, Denise Scott Brown, and Michael Graves sought a new way to relate their work to the past, while grounding it in the present, rejecting what they saw as the stale repetition of Modernism. They rejected its idealism of a universal, transcendent architecture and its Modern abstractionism in favor of architecture designed specifically to relate to its place and function. They wanted to make what was ahistorical historical again,

The Postmodernists, too, were influenced by classical architecture but used it in a referential, more literal way. Rather than grounding their work in classical ideals made modern by new technology, the Postmodernists deconstructed classical architecture and used its elements as words in a vocabulary, speaking directly to the viewer. Whereas the Modernists' absorption of classical ideals borders on the reverent, the spiritual, the Postmodernists' referential use speaks more literally, and more loosely, to the importance of the classical in western architecture. For those who became the Postmodernists, Modernism had failed; it had became static and confining in its standardization. They sought a fresh approach, a break from what had become the “"canonic’ Classical.”48 Michael Graves is the Postmodern architect who most directly makes use of classical references in this new way. Like the classical Romans, whose work he studied, he combines elements from various architectural styles. For Graves, this

\footnotetext{
${ }^{48}$ Powell, Graves Residence: Michael Graves, 27.
} 
merger represents a multi-layered language that speaks to the present as well as the past.

Michael Graves was born in Indianapolis, Indiana, in 1934, between the world wars. He received degrees in architecture from the University of Cincinnati (B.S. 1958) and Harvard University (M.Arch. 1959). Since 1962, he has taught at Princeton University (where he now is emeritus professor) and practiced architecture in his Princeton firm. ${ }^{49}$ Under the influence of Modernism, Graves became an avid proponent of the style early in his career. He and his peers had been trained in this school, in the work of Le Corbusier, Mies van der Rohe, Walter Gropius, and Marcel Breuer. Graves’s early work reflects this training.

Graves and his contemporary, Peter Eisenman (born 1932), hoping to invigorate a rather static architectural field, in 1969 helped establish the CASE (Conference of Architects for the Study of the Environment) group, which sponsored gatherings of architects and critics at Princeton, MIT, and in New York. This group was the spark for the "New York Five," group of architects known for their white, Modernist architecture. The group included architects Peter Eisenman, Michael Graves, Charles Gwathmey, John Hejduk, and Richard Meier and was based on their common allegiance to the 1920s and '30s "white” work of International Style architect Le Corbusier and to the ideas of the influential architect and critic Philip Johnson. The New York Five were trained first as Modernists but began in the 1960s to expand and then break out of the Modernist mold. Indebted to the International Style architects of the early twentieth century, they began to challenge that style's formal rules, to deconstruct elements and rearrange them in a purely formal investigation. They were not interested in Modernist ideals.

\footnotetext{
${ }^{49}$ Michael Graves \& Associates, Princeton, New Jersey

50 The name came from a Museum of Modern Art exhibition organized by Arthur Drexler in 1967 and the subsequent 1975 book, Five Architects (New York: Oxford University Press).
} 
There is a clear comparison between Michael Graves’s 1967-69 Hanselmann House in Fort Wayne, Indiana (plate 43) and Le Corbusier's National Museum in Tokyo, built a decade earlier (plate 42). The ancient classical idea of procession, expressed in the steps and bridge, is present in both buildings. So is the tight geometry, but Graves begins to open up his space, to break it apart.

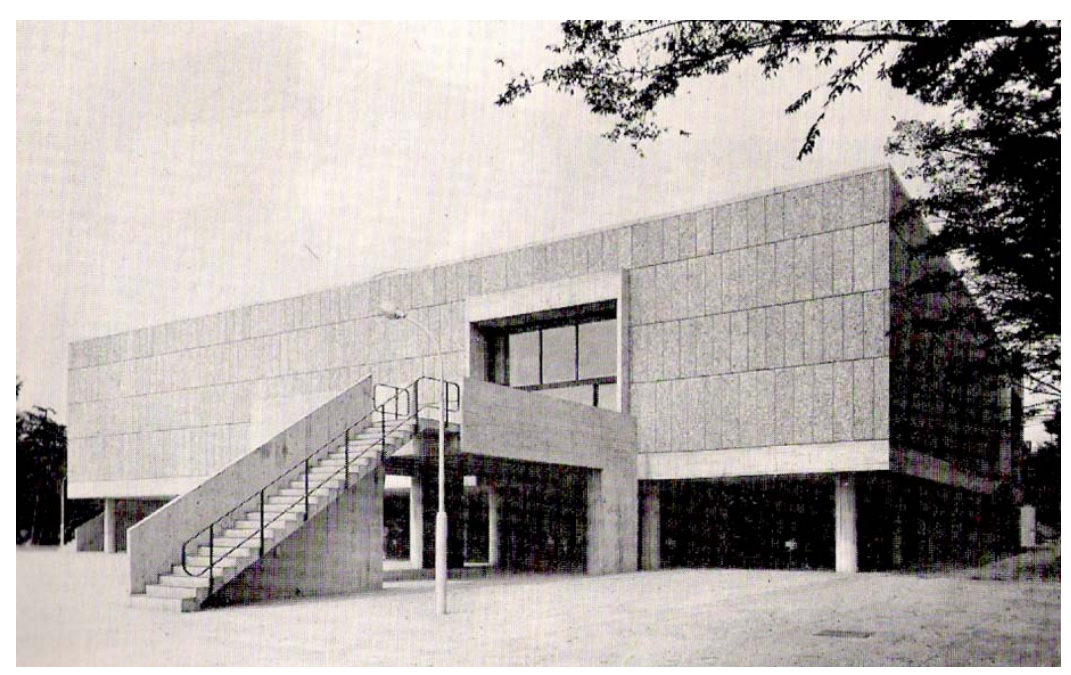

Plate 42. Le Corbusier with Kunio Maekawa, Junzo Sakakura and Takamasa Yoshizaka, National Museum of Western Art, Tokyo, Japan, 1959

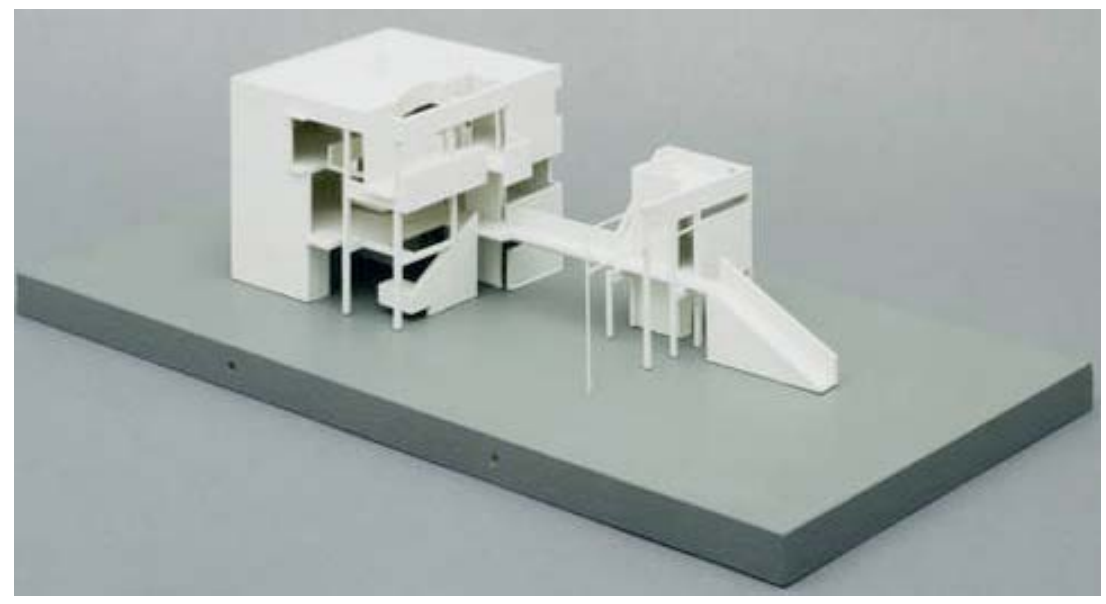

Plate 43. Michael Graves, Hanselmann House, Fort Wayne, Indiana, 1967-68 
Peter Eisenman, in his 1969-70 Falk House in Hardwick, Maine (plate 44), opens his house even farther, beginning to deconstruct the walls. He still holds onto the Modernist color scheme and the strong geometry of the grid.

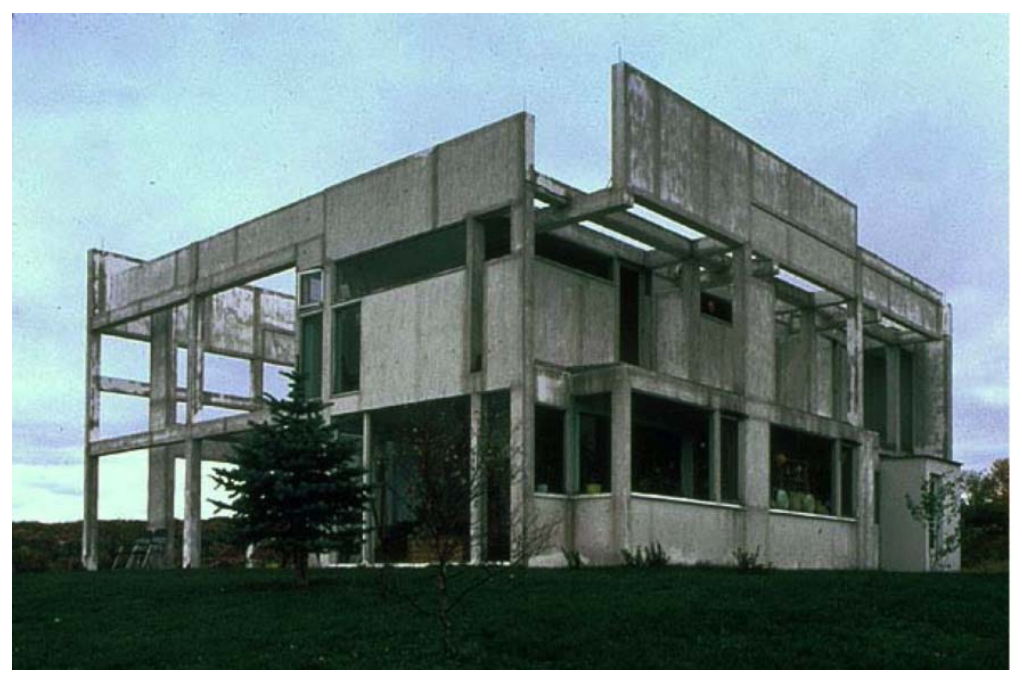

Plate 44. Peter Eisenman, Falk House, Hardwick, Vermont, 1969

Heavily influenced by two years of study at the American Academy of Rome (196062), as a recipient of the Prix de Rome, Graves became interested in the relevance of contemporary architecture to the field's historical development. He spent two years drawing and painting the buildings and ruins around him. He recorded what he saw in numerous sketches and photographs, preserving for his own future reference the elements of classical architecture that would become the vocabulary for his own architecture: "The extraordinary experience of two years at the American Academy in Rome in the early 1960s transformed how I looked at the world around me. In that rich and marvelous city, I came to understand architecture as a continuum from antiquity to the present day, and thus as a language. ${ }^{, 51}$ Rather than focus on the details of buildings, Graves represented their mass through geometry and abstraction (plate 45). He drew buildings from different angles and in varying scale. These

${ }^{51}$ Michael Graves, introduction to Michael Graves: Images of a Grand Tour, by Brian M. Ambroziak (New York: Princeton Architectural Press, 2005), ix. 
variations in scale point to his later work, in which he combines elements of different sizes, often greatly exaggerated, in a single building. Through the sparing use of line and a reliance on simple outline and shadow, he recorded the shape and volume of structures he wanted to remember while sketching in Rome. ${ }^{52}$ Through photography, he recorded color schemes that would become his signature in his postmodern work: blues of the sky and brick and oranges (earth tones) of the ancient ruins (plates $46 \& 47$ ). A grand tour ${ }^{53}$ such as Graves's was not new to those interested in classical ideas. ${ }^{54}$

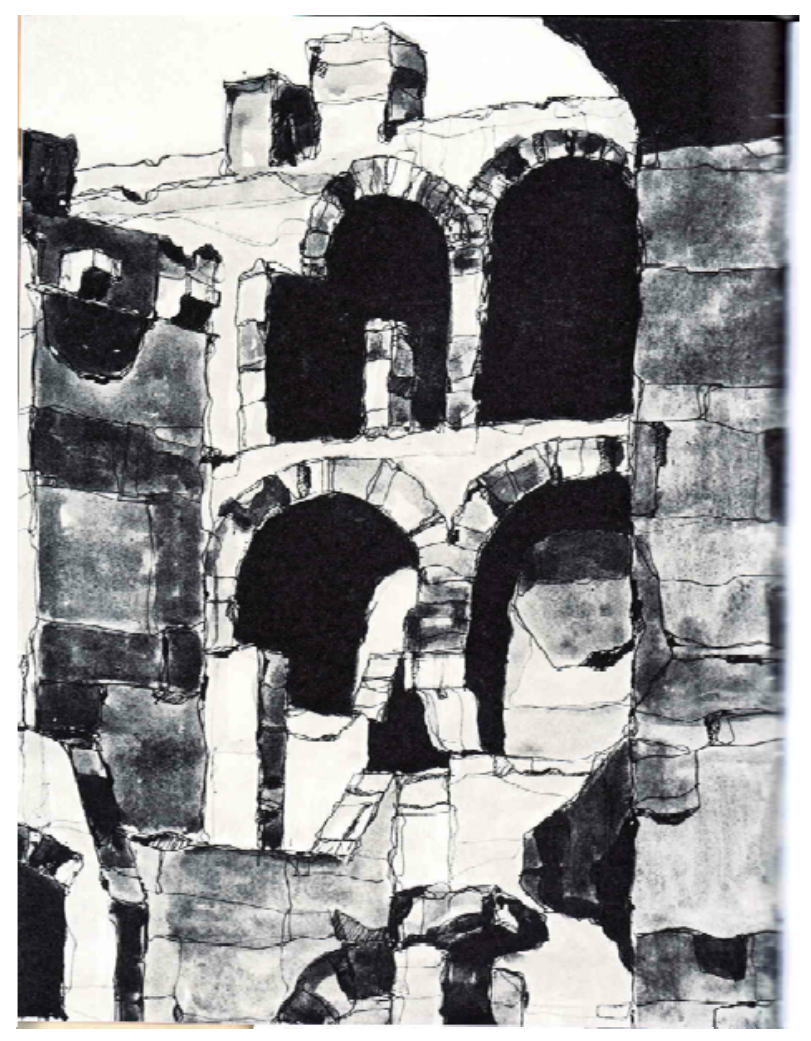

Figure 45. Michael Graves, Santo Stefano Rotondo, Interior, Caelian Hill, Rome, Italy, c. 1960-62, pencil sketch

${ }^{52}$ Brian M. Ambroziak, Michael Graves: Images of a Grand Tour (New York: Princeton Architectural Press, 2005), 11.

${ }^{53}$ Ibid. This is the name by which Ambroziak calls Graves's exploration of the classical world.

54 "In the seventeenth and eighteenth centuries, wealthy British men and women travelled across Europe, absorbing its cultural and architectural highlights in what became known as the 'Grand Tour'. They were inspired by books... on science, travel, art and architecture, plus the writings of Ancient Greece and Rome.... Venice,

Florence, Rome and Naples were the highlights of any Grand Tour. The ruins of the Roman Empire...were deemed especially important. As they travelled the tourists studied, busily drawing and making notes. They also collected cultural artifacts.” (Architecture,com, Royal Institute of British Architects, www.architecture.com/LibraryDrawingsAndPhotographs/Palladio/AndreaPalladio/TheGrandTour.aspx) 


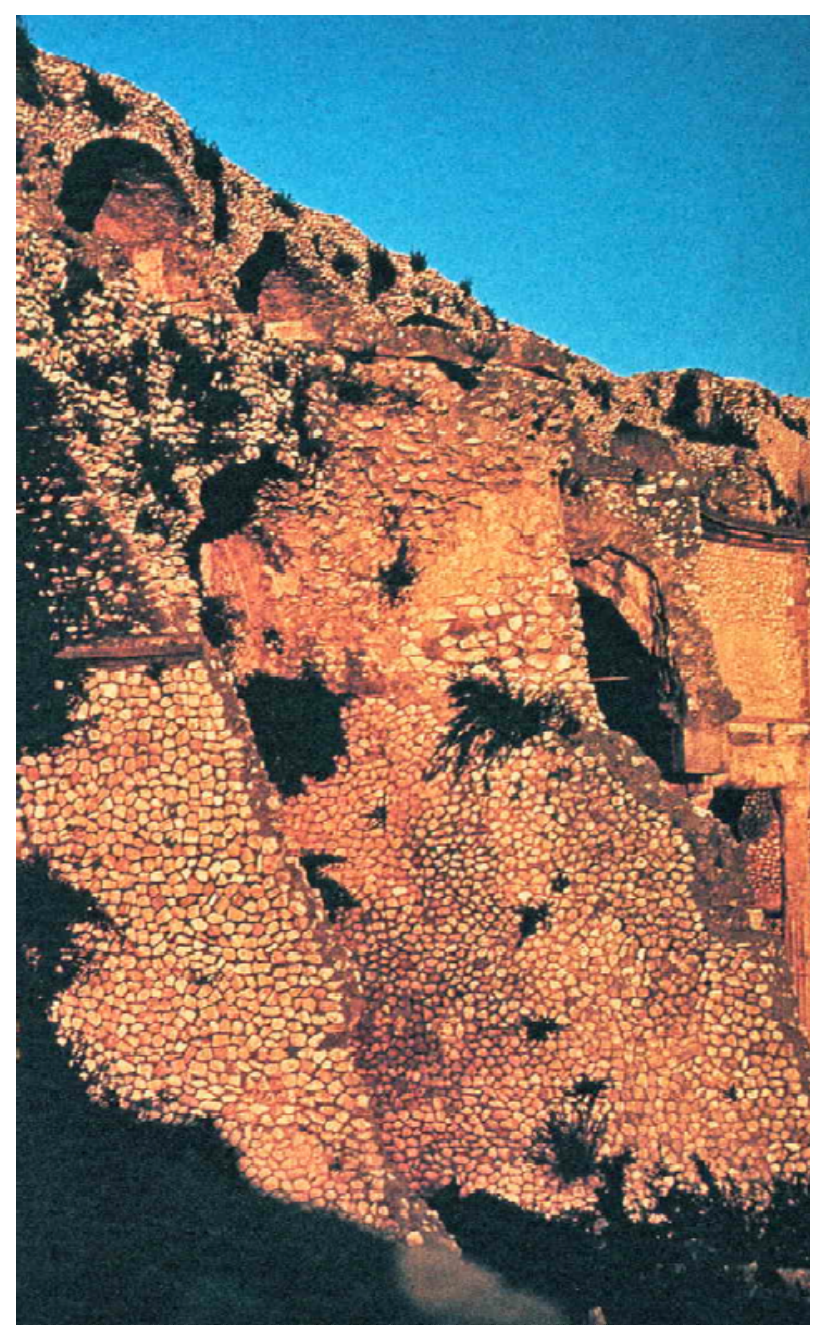

Plate 46. Graves, Santa Rosalina, Palestrina, Italy, 1961, Kodachrome slide (Photo by Michael Graves)

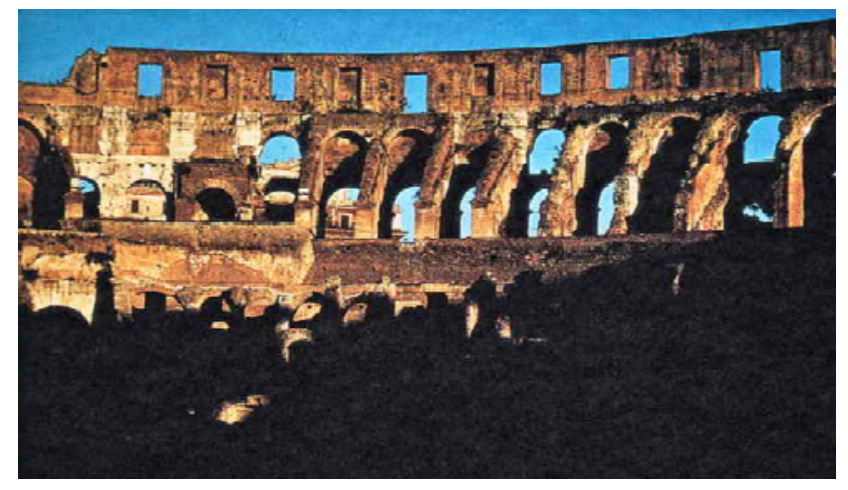

Plate 47. Graves, Flavian Amphitheatre, Colosseum, No. 1, Imperial Forums, Rome, Italy, 1961, Kodachrome (Photo by Michael Graves)

In the 1960s and '70s, Graves continued to develop his own modernist style, in increasingly symbolic terms. His 1969 Benacerraf House in Princeton, New Jersey, is even 
more deconstructed and open than Eisenman’s Falk House of the same year. Graves also began to add more color to his work, in the form of stand-alone, non-structural elements that seem to have been added, as opposed to the rest of the design, which is consistently deconstructed but remains a unified shell. Graves began to feel that Modernism did not offer an easily understandable message and turned to symbolism to overcome what he saw as the shortcomings in communication of the Modernist design. He rejected the sleek, streamlined glass and steel architecture of the Modernists and came to be considered a Postmodernist who focused his interests on symbolic reference to the orders of classicism. He rejected the Modernist focus on the machine and industry.

Modern architects, such as Mies and Le Corbusier, who had begun their careers in the early twentieth century, were reacting to national divisions that led Europe into World War I. They held the hope that a transcendent, unified architecture could unite people. A half century later, the Postmodernists were perhaps reacting to what they saw as an architecture disconnected from its time and place. They sought to make architecture historical again and wanted to create buildings that communicated with their users through recognizable elements. Whereas the Modernists sought to order and unify a divided society through architecture that transcended time and place, the Postmodernists strove to link architecture once again to its place and function, to ground it. The Modernists celebrated the possibilities brought about by the new materials and technology of their time. The Postmodernists questioned modern architecture as devoid of readable reference. The Modernists sought to transcend national and social differences by creating an architectural standard that integrated time-tested ideals and new technology. The Postmodernists sought to create a new vocabulary specific to each building, made up of a combination of visual references combined differently for each site. The 
Modernists sought an ideal that would stand the test of time. The Postmodernists sought to ground their work in the specific culture for which it was built. The Modernists were idealists optimistically exploring a new technology. The Postmodernists tended to be ironic in their deconstruction of accepted form. Whereas Mies, for example, created a cohesive building type based on his architectural ideal, Graves combined references from different styles in a sort of collage symbolizing the various influences appropriate to each building.

Robert Venturi (born 1925) played a key role in the development of Postmodern architecture. In 1972, he and his wife and partner, Denise Scott Brown (born 1931), published Learning from Las Vegas: the Forgotten Symbolism of Architectural Form, ${ }^{55}$ his second manifesto on architecture. In this book, he and Brown, along with Steven Izenour, rejected the strict rules set by the early Modernists in favor of stylistic references with which they thought they could better communicate with the public. He argued that decoration was important for communication, would give the viewer room for interpretation, and would be true to its time. The many layers of meaning in his work reflected the pluralism of the new "post modern" age.

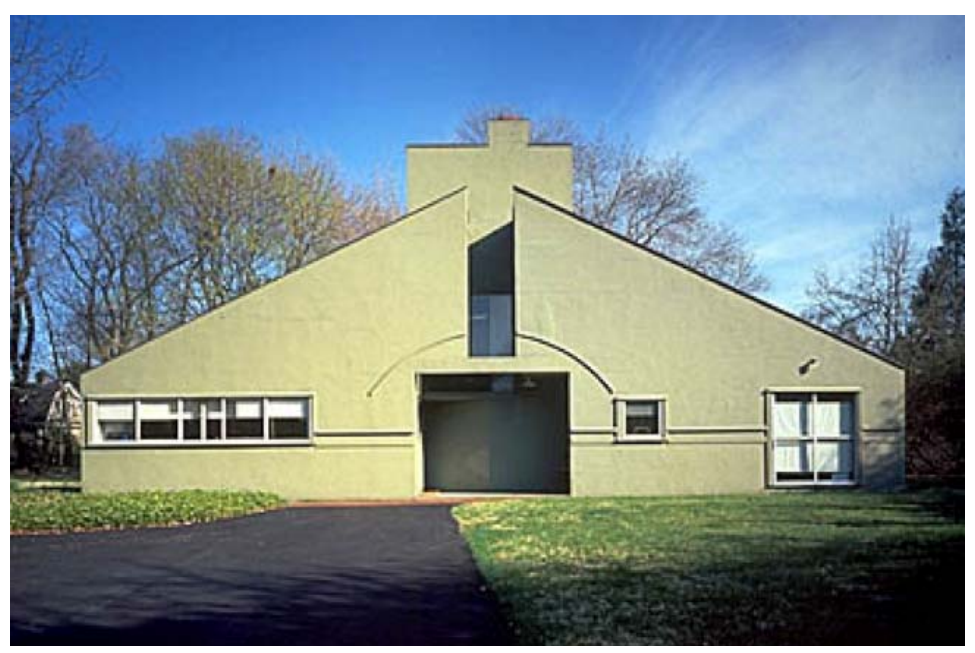

Plate 48. Robert Venturi, Vanna Venturi House, Chestnut Hill, Pennsylvania, 1962 (Photo by Maria Buszek)

${ }^{55}$ Robert Venturi, Denise Scott Brown, and Steven Izenour, Learning from Las Vegas (Cambridge, MA: MIT Press, 1972). Based on a 1968 trip with students to study the Las Vegas stip. 
Venturi’s Vanna Venturi House, 1962, Chestnut Hill, Pennsylvania (plate 48), generally is accepted as the first building to clearly define what later came to be called Postmodernism. Here are the familiar elements of the Modernist style turned on their heads: minimal color, ribbon windows, and geometric shapes but now combined with elements from the vernacular, such as the pitched roof and the prominent chimney. Venturi combines universal Modernist elements with those common specifically to houses.

Following Venturi’s logic, Michael Graves made particular use in his work of ancient Roman and Greek elements. Although his work combines historical references to a number of architectural periods, classical elements play a major role. Unlike Modernists such as Mies van der Rohe, Graves’s classical elements are references rather than parts of a unified classical design. Graves's classicism is expressed in single elements reminiscent of the past, geometric forms that are put together, often as decoration, sometimes like building blocks. (It is interesting to note that Graves later designed building blocks for children that are the same shapes as many of these elements.)

Unlike the Modernists, especially Mies, for whom the classical ideals of proportion and geometry were central to the work, Graves’s classical elements serve as a kind of pastiche, assembled in varying arrangements according to the symbolism appropriate to each building. It is in Michael Graves’s 1977 Plocek Residence in Warren, New Jersey (plate 49) that his mature style is visible. He has completely broken apart the Modernist structure and put it back together piece by piece. The walls are solid, in contrast to the transparency of the Modernist glass wall. Graves has added color and combined elements in a sort of collage. 


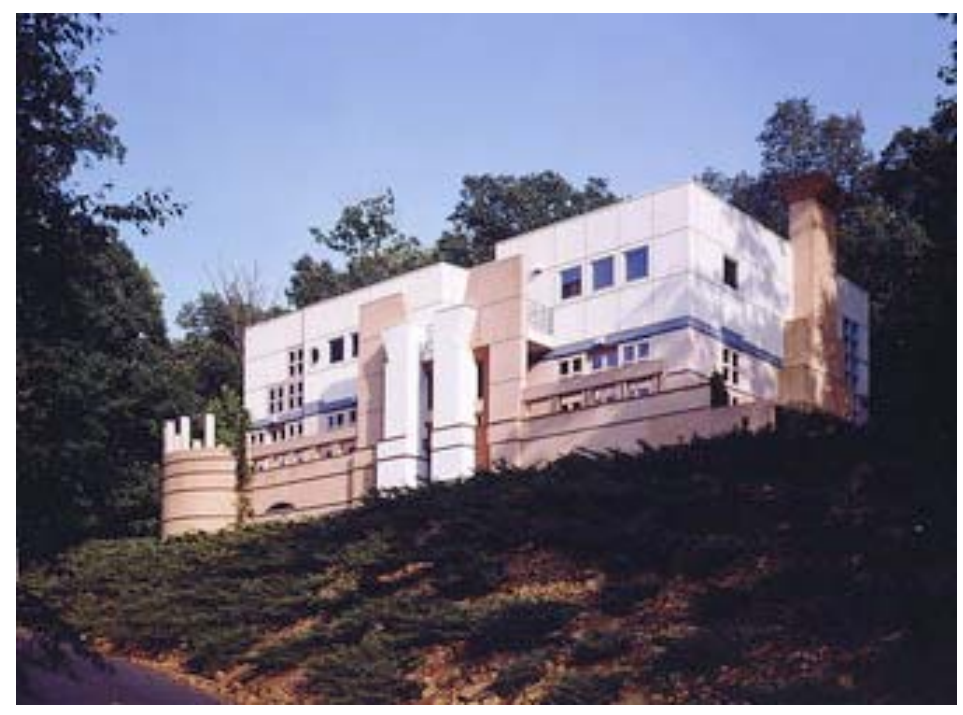

Plate 49. Graves, Plocek House, Warren, New Jersey, 1977

The elements retain strong classical references. On the center of the façade are two white column shapes, each with a shaft and capital. There are red horizontal stripes across the lower section of the building, much like the Roman wall construction that we will discuss later. Like Venturi, Graves combines these elements with others that are symbolic of the building's residential function, such as the large chimney and the windows with four glass panes. Graves relies on geometric shapes put together in a way that is unique to this particular building. In the living room (plate 50), there are two white marble-like columns, prominent references to classical stone columns. 


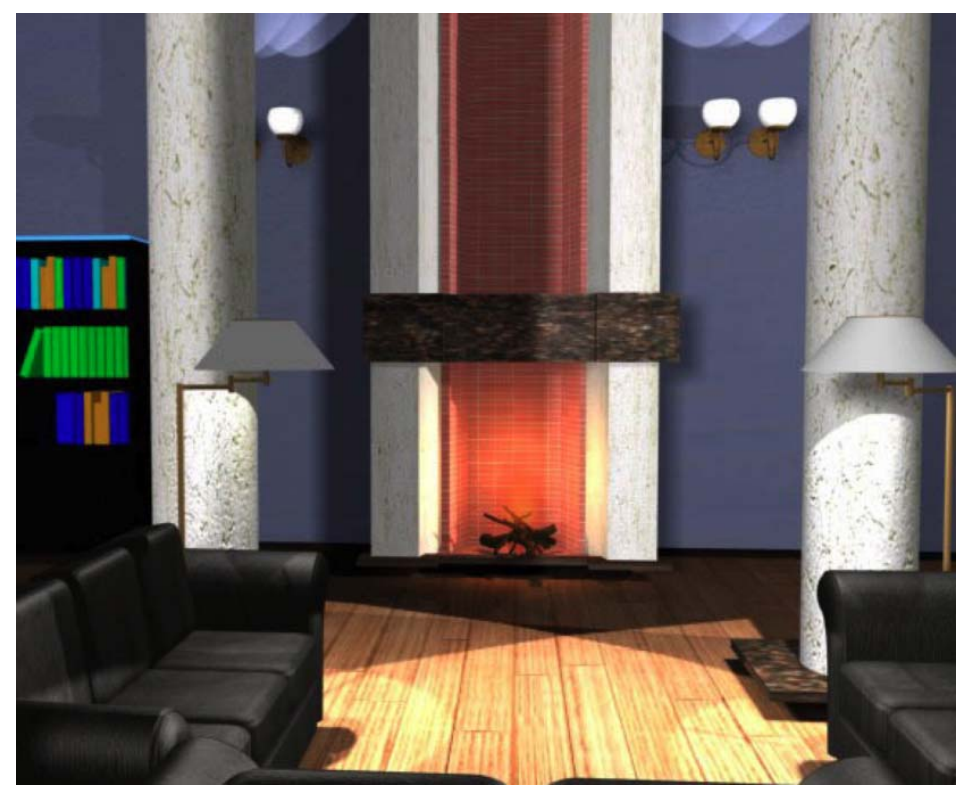

Plate 50. Plocek House living room with columns

In his own house in Princeton, New Jersey (plate 51), on which he has been working since the 1970s, Graves placed a prominent Doric column (along with other classical elements) in the living room. In his later Florida post office building (plate 52), an oversized tholus (or column shape) serves as the main entrance hall, and a colonnade stretches along one wing of the building. 


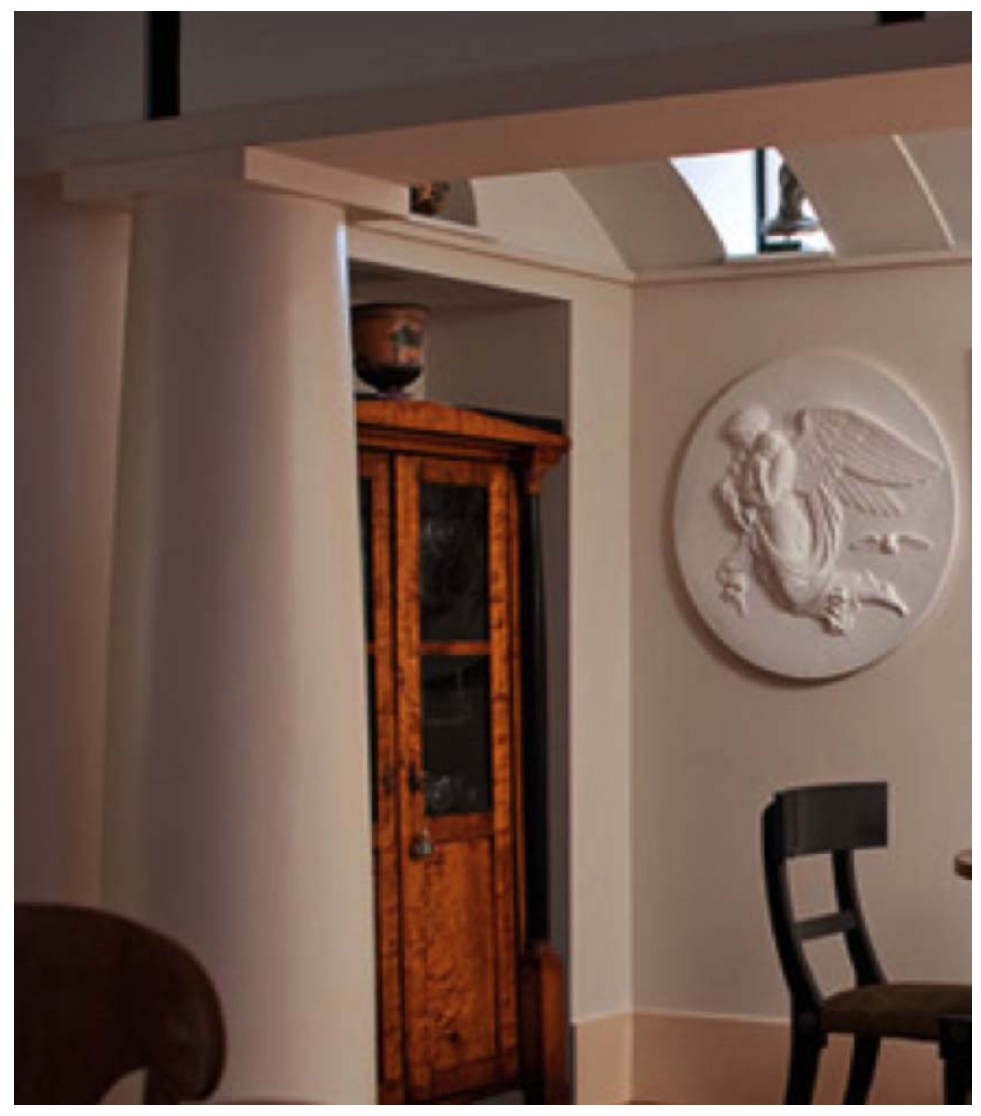

Plate 51. The Warehouse, Graves's home living room with column, Princeton, New Jersey, 1970s-present (Photo by John Bessler)

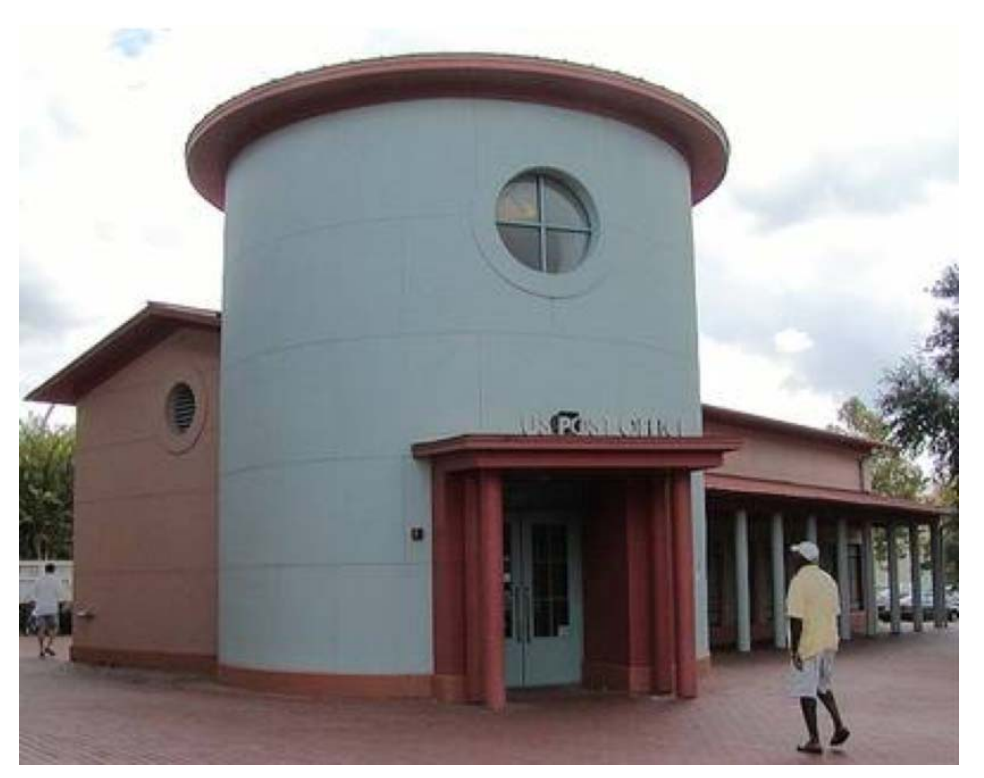

Plate 52. Graves, Post Office, Celebration, Florida (Photo by Jackie Craven) 
Whereas Modernist architects fully incorporated classical ideals into their design, Mies's goal was to express classical ideals through the use of modern materials, expressing one in terms of the other. These ideals are visible in his Mellon Hall of Science, with its regular symmetry and column referencing I-beams. Postmodernists use classical elements as signs, elements that are to be read as individual references. Graves applies classical elements onto his designs. Modernists distilled classical ideas and embedded them into theirs.

Graves's classical elements are employed as easily recognizable signs that can be added to any building to give it historical reference. These references are readable as a style with which most people are familiar, either consciously or subconsciously to signify a particular meaning (signifiers). Through the use of allusion, whimsy, and somewhat detached irony, Graves creates an architectural language or shorthand reference that viewers can read (what is signified). In a world of increasingly immediate gratification, sound bites, and fragmentation, his architecture serves a composite of disconnected elements rather than the integrated whole the Modernists sought to create.

The Postmodernists returned to earlier design processes, such as those of the Italian Renaissance. Through drawings, "the [Renaissance] building was imagined as an additive composition of elementary volumes. The choice of elements was determined by a generally accepted typology...but the composition changed to become integrative.... The architect started with a vision of a hierarchy of forms, all of which [had] a figurative identity."

Jean Baudrillard (1929-2007) the French Poststructuralist philosopher of semiotics, said that an object's meaning is only understandable through its relation to the meaning of other objects and discussed self-referentiality. These ideas were formulated at the same time as

\footnotetext{
${ }^{56}$ Karen Vogel Nichols, Patrick J. Burke, and Caroline Hancock, eds., Michael Graves: Buildings and Projects 1982-1989 (New York: Princeton Architectural Press, 1990), 7.
} 
Graves's and relate strongly to Graves's work. The manner in which Graves places unrelated elements from different eras side by side is an attempt to make them relevant to one another. (More often than not, classical elements are used together with a more recent style.) These elements often are presented on a scale that differs from the other elements and causes them to call attention to themselves in a self-referential way.

Whereas Mies and his contemporaries were looking to unify a fragmented humanity through a universal ideal transcending individual differences, Graves and his colleagues reacted to the increasing blending of ideas in their culture, combining references from different eras to create a readable story. Both of these architectural styles require some amount of architectural knowledge to fully understand, but each, in its own way, uses time-tested, familiar elements to appeal to a society whose history has long accepted those elements as a basis for its civic foundation. In his seminal article, “A Case for Figurative Architecture,” Graves talks about the need to return to an architectural language, a language "rooted in figurative, associational attitude.” He explains

The Modern Movement based itself largely on technical expression...[and] undermined the poetic form in favor of nonfigural, abstract geometries.... [I]t is important to keep the technical expression parallel to an equal and complementary expression of ritual and symbol.... It is crucial that we re-establish the thematic associations invented by our culture in order fully to allow the culture of architecture to represent the mythic and ritual aspirations of society. ${ }^{57}$

It is important for Graves that his buildings relate to their function and their site.

Graves’s 1982 Portland Public Service Building, in Portland, Oregon (plate 53), refers to classical civic architecture in a highly symbolic way. In this landmark building, we again see the tripartite classical column, with its blue-green base; tan and brown main section, or shaft; frieze just above the shaft; and gray capital or roof. There are column references also in the sections

\footnotetext{
${ }^{57}$ Michael Graves, “A Case for Figurative Architecture,” in Michael Graves: Projects and Buildings 1966-1981, eds. Karen Vogel Wheeler, Peter Arnell, and Ted Bickford (New York: Rizzoli, 1982), 11.
} 
with brown vertical stripes reminiscent of column fluting, and with capitals. (In an interesting play on the way a capital normally would overhang the shaft, Graves recesses it, as a reversal of the classical model.) The giant keystone shape is a reference to the widespread Roman use of the arch, which they perfected.

Graves’s drawing, “Rome, 1981,” shows how his mature architecture was indebted to ancient Roman architecture. Christian Norberg-Schulz says in his essay, "Michael Graves and the Language of Architecture,” that Graves wanted to develop an integrated and versatile language from the inventory of whole and partial figures he had amassed from this source. (Again, Graves’s years in Rome can be credited for the development of this inventory, refined from his own drawings.) Norberg-Schulz continues, "One might perhaps expect that buildings based on such conventional forms would become manifestation of a superficial historicism. Like the words of spoken language, however, the basic figural forms may be interpreted in ever new ways without losing their essential meaning., 58

Like Louis Sullivan’s 1895 Guaranty Building, the Portland Building refers to the classical column and its human associations, with a recognizable base (foot), shaft (torso), and capital (head), but on a much grander scale. Classical elements, such as the surface ornamentation representing the column with fluting, the frieze around the top of the building, and the repeated square, are presenting exaggerated form. The function of the building, housing civic offices, also refers effectively back to the classical public building.

\footnotetext{
${ }^{58}$ Christian Norberg-Schulz, "Michael Graves and the Language of Architecture," in Michael Graves: Buildings and Projects 1982-1989, Karen Vogel Nichols, Patrick J. Burke, and Caroline Hancock, eds. (New York: Princeton Architectural Press, 1990), 11.
} 


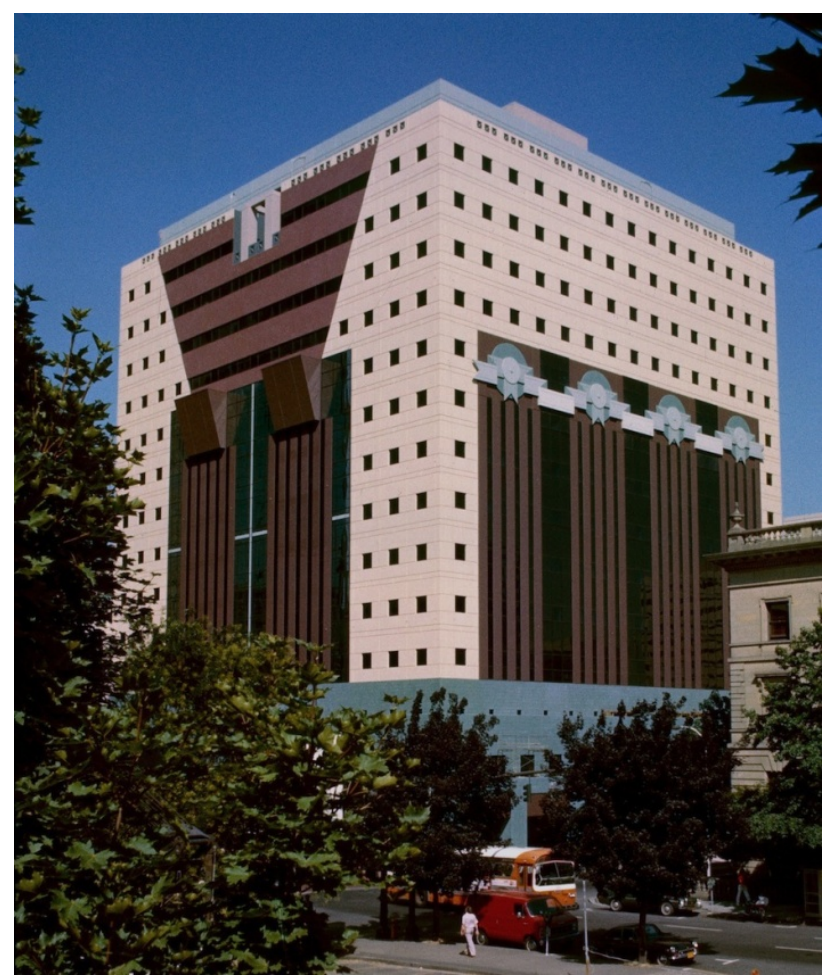

Plate 53. Graves, The Portland Public Service Building, 1982 (Photo by Steve Morgan)

Turning now to another, lesser-known Graves building will reveal more about how he combines classical elements with other elements related more specifically to the project at hand. 


\section{Erickson Alumni Center}

Michael Graves’s Erickson Alumni Center, 1984-86 (plate 54), is located on the West Virginia University campus in Morgantown, West Virginia. The building originally was designed as an office for the employees of the WVU Alumni Association and a meeting place for alumni and friends of the University. It is now being renovated and will serve as the University Museum Education Center. The building's banquet hall also was used by community members for wedding parties and other celebrations. A WVU alumnus with personal ties to Michael Graves asked him to design the Erickson Center.



Plate 54. Graves, Erickson Alumni Center, West Virginia University, Morgantown, West Virginia, 1984-86 (Photo by Michael Slaven)

The original project goals called for a structure "to become the first and lasting impression of the campus and its alumni... a gateway to the future and a reminder of the past." ${ }^{59}$ A "reminder to the past” is particularly appropriate to the work of Graves, who combines elements from many periods in one building. In this building, he combined references to two main architectural periods or building types: classical architecture of ancient

\footnotetext{
${ }^{59}$ Information from unidentified article on the building.
} 
Greece and Rome and the contemporary country estate or lodge. This analysis will consider the references to the country estate and their meaning in this work, but will focus mainly on his references to classical elements.

The Erickson Center was fashioned after a country estate on a wooded site. ${ }^{60}$ The building was designed to give alumni a feeling of "coming home," of welcome to a familiar and comfortable place, to make them want to return to the university. The site, a fairly large, slightly sloped, lightly wooded area on the edge of the university's Evansdale campus is adjacent to a major thoroughfare and well suited to Graves’s reference to a country estate. He nestled the structure into the site, placing the main entrance on the top of a ridge so that the visitor must proceed over a short bridge from Fine Arts Drive to the front door. The back of the building, on the down-hill side, faces a main thoroughfare (Patteson Drive) and is visible from blocks away in either direction.

The main structural elements suggesting a country house are: a pitched, shingled roof with large chimney (plate $55 \& 56$ ); windows with (faux) panes (plate 57); a pronounced downspout at one end of the building (plate 58); trellises on the exterior walls (plate 58); the house set back from the main road (although the entrance is from the other side, a necessity for traffic reasons); and a large patio in back (plate 59). Inside, the two-story banquet hall has a large fireplace and a vaulted ceiling with wooden beams (plate 60), giving the feeling of a country lodge.

\footnotetext{
${ }^{60}$ Ironically, although this site originally was heavily wooded, many trees were cut down in preparation for the building.
} 


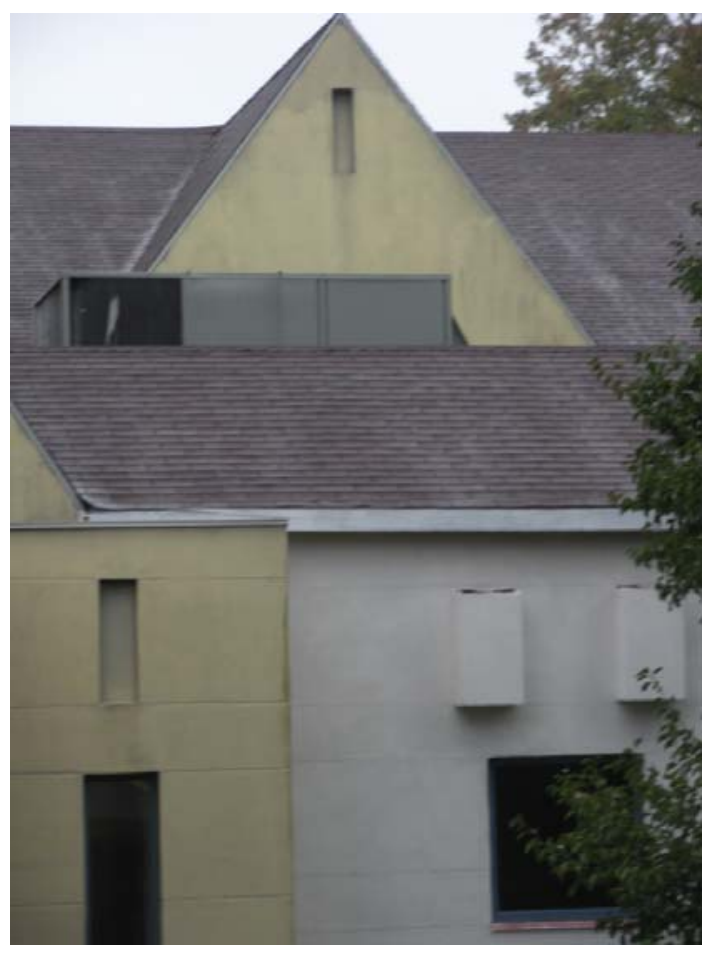

Plate 55. Erickson Alumni Center pitched, shingled roof (Photo by Michael Slaven) 


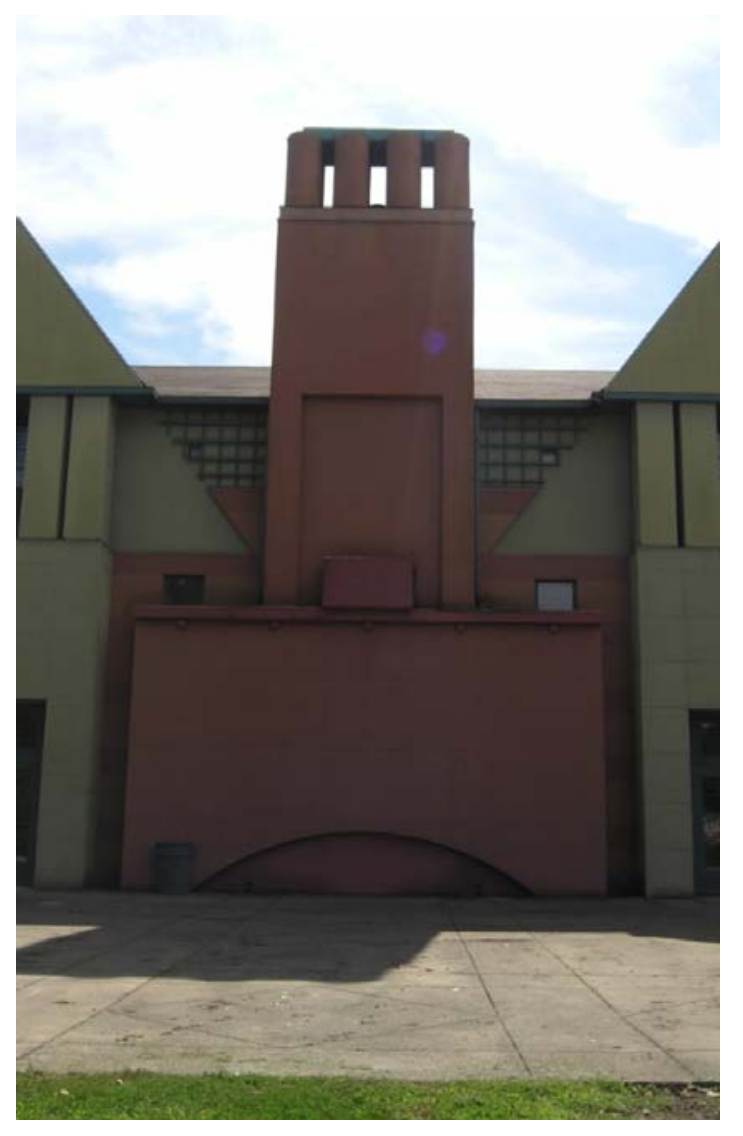

Plate 56. Erickson Alumni Center chimney (Photo by Michael Slaven)

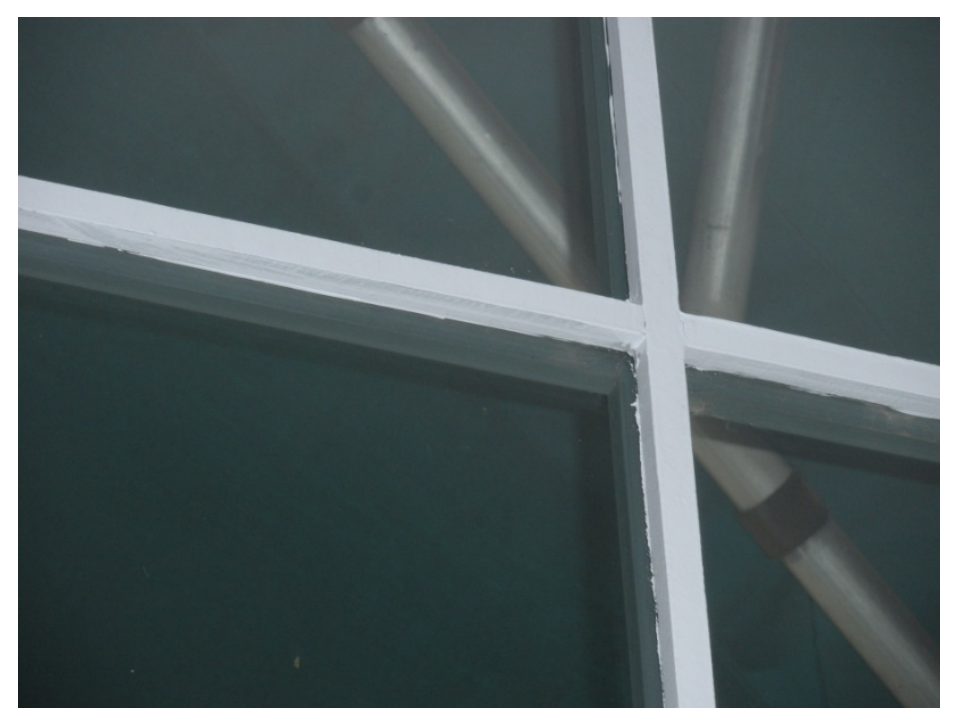

Plate 57. Erickson Alumni Center faux pane windows (Photo by Michael Slaven) 


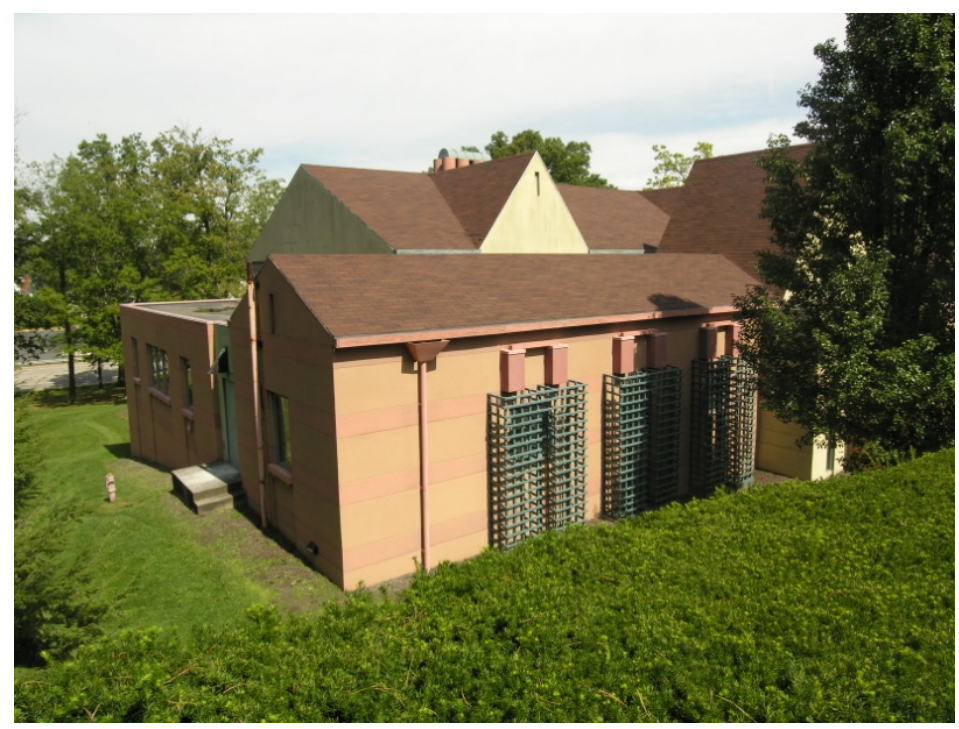

Plate 58. Erickson Alumni Center downspout and trellises (Photo by Michael Slaven)

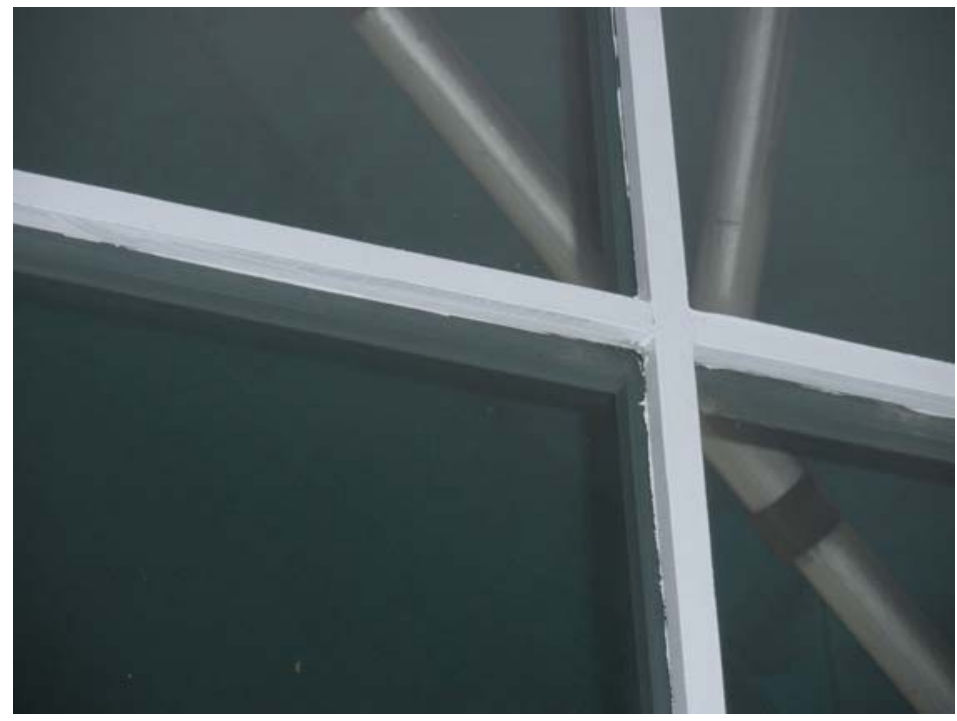

Plate 59. Erickson Alumni Center patio (Photo by author) 


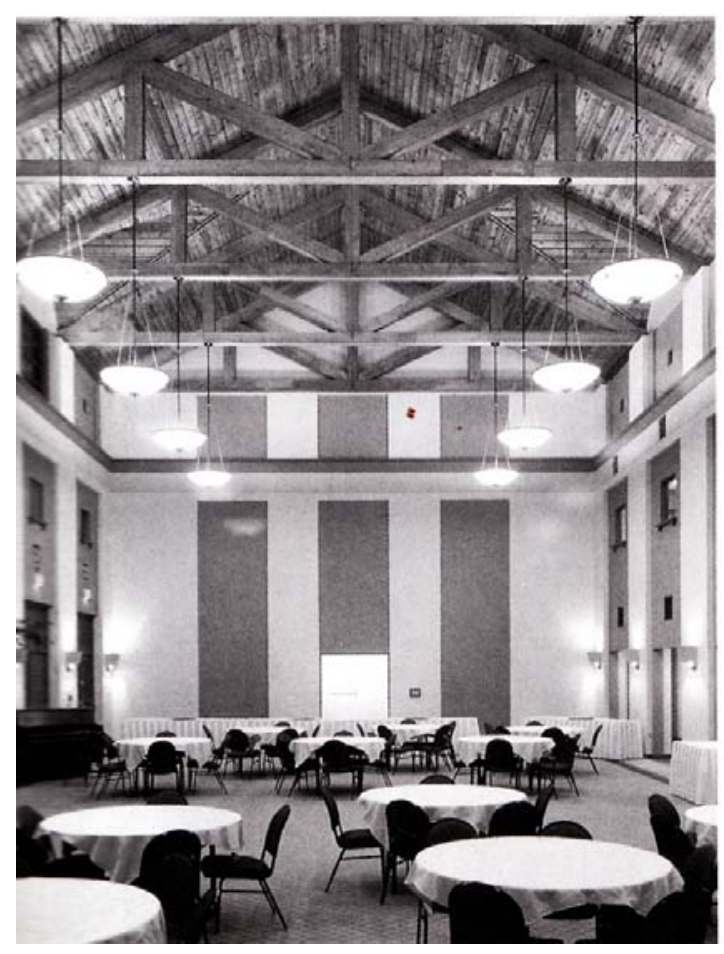

Plate 60. Erickson Alumni Center Great Hall, 1986 (Photo by Paul Warchol)

Graves's ability to evoke memories and thus make the building gain a local and temporal meaning also distinguishes his Erickson Alumni Center at West Virginia University, where concrete figures such as gables, dormers, and dominant chimney stack create that particular "domestic-institutional: quality that makes life at many American colleges so pleasingly significant. ${ }^{61}$

Unlike Mies, Graves did not place great emphasis on the materials used in the structure of the building, which here consists of a wood frame with steel joists and concrete f1oors. The building materials are hidden, in many cases, or painted over to look like something other than the everyday materials they often are. Some materials are references to particular architectural ones commonly used in familiar building types. Those that refer to the country house are the synthetic plastic exterior finish that looks like stucco (a sand coating over Styrofoam), wooden trellises that looks like metal, and wooden ceiling beams in the great hall. Some of these

${ }^{61}$ Christian Norberg-Schulz, "Michael Graves and the Language of Architecture," 11. This is the only direct reference to the Erickson Center that the I found by any prominent critic or historian. 
elements refer also to the modern period: the trellises are made of wood but look like metal grids. ${ }^{62}$ The chimney is topped with closely-set column forms supporting a barrel or oil drum shape on its side in reference to the modem industrial age, possibly the English chimney pot. This same shape appears in paintings by Graves (plate 61).

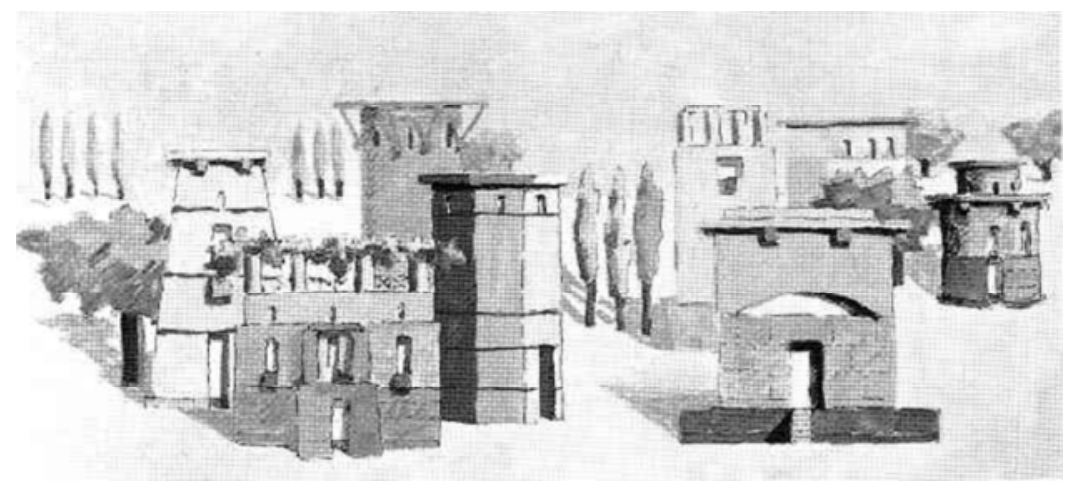

Plate 61. Graves painting with chimney pots.

Strong geometric forms also relate to the Modernist interest in reducing forms to their geometric essence. There are features that quote other architectural periods, too, but this study will focus on the ways this building refers to classical architecture.

The building's front entrance, nestled into the hill, makes immediate and clear reference to classical architecture. ${ }^{63}$ The building is a two-story structure reminiscent of a house, but the references are abstracted through the use of simple geometric shapes that act as building blocks as well as decoration. Although the building is predominantly horizontal, the strong geometric shapes add verticality. The most prominent shape is the triangle, a shape with a strong reference to the classical pediment (plate 62). Three very prominent triangles appear over and near the building entrance: one over the entrance foyer itself and two that form

\footnotetext{
${ }^{62}$ Graves worked for Walter Gropius on his Baghdad University project in the 1960s, and the grid is fundamental to the design of Gropius' work.

${ }^{63}$ There also is reference here to procession, as was the case with ancient classical architecture, in which the visitor approached from a single direction, by means of monumental steps, toward the entrance. Modernist architects, such as Le Corbusier in his Villa Savoye and, later, his Tokyo Museum, even more dramatically directed procession into (and through) his buildings. Graves adopted this same focus on procession in his Hanselmann House and, in a more subtle way, in his footbridge leading to the entrance of the Erickson Center.
} 
dormer shapes just beyond on either side of the entrance. The large triangular pediment shape over the entryway sits just behind another classical element, a truncated column-like shape, or tholus, that greets the visitor immediately upon approach to the front door (plate 63). This tholus supports nothing and, therefore, stands as a clearly symbolic element. As a cylindrical shape, this element suggests both a Doric column and a rotunda. It has minimal decoration; a simple base-like bottom, widely-spaced pilasters around its shaft, and a simple, flattened disk for a capital. Suspended under the projecting edges of the "capital” is a design of dentil molding, which is repeated inside the building in numerous locations. The tholos itself is set upon a two-step platform reminiscent of the Greek stereobate. (The original design called for the column to be supported by two smaller shafts instead of this platform and did not include the canopy over the entrance, plate 64.)

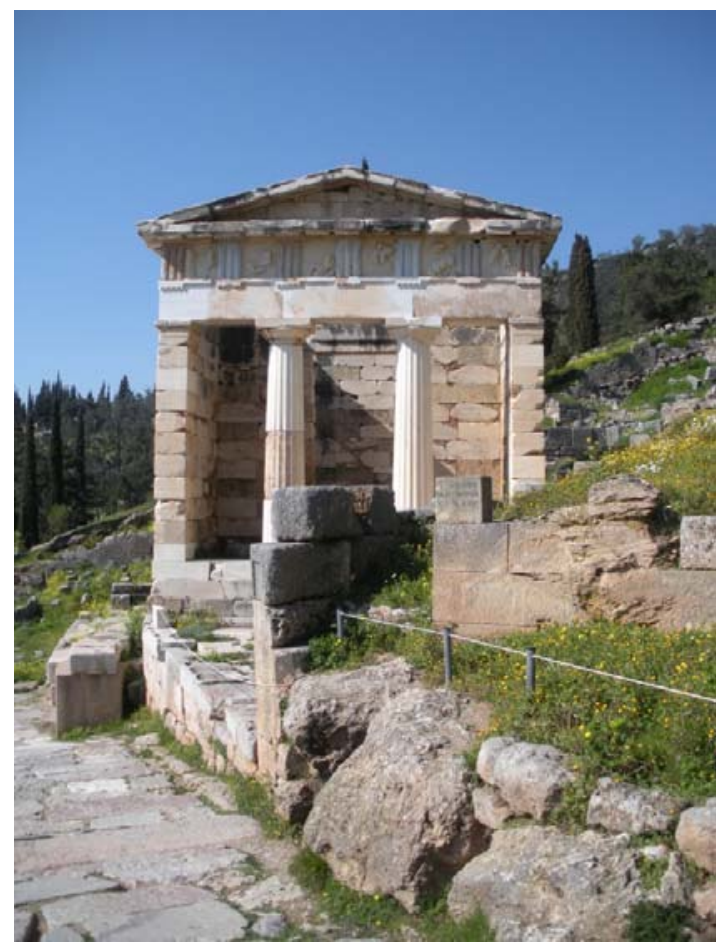

Plate 62. Treasury of Athens, Delphi, Greece, fifth century B.C.E. (Photo by Buffy Vehse) 




Plate 63. Erickson Alumni Center with tholus shape over entrance (Photo by Michael Slaven)

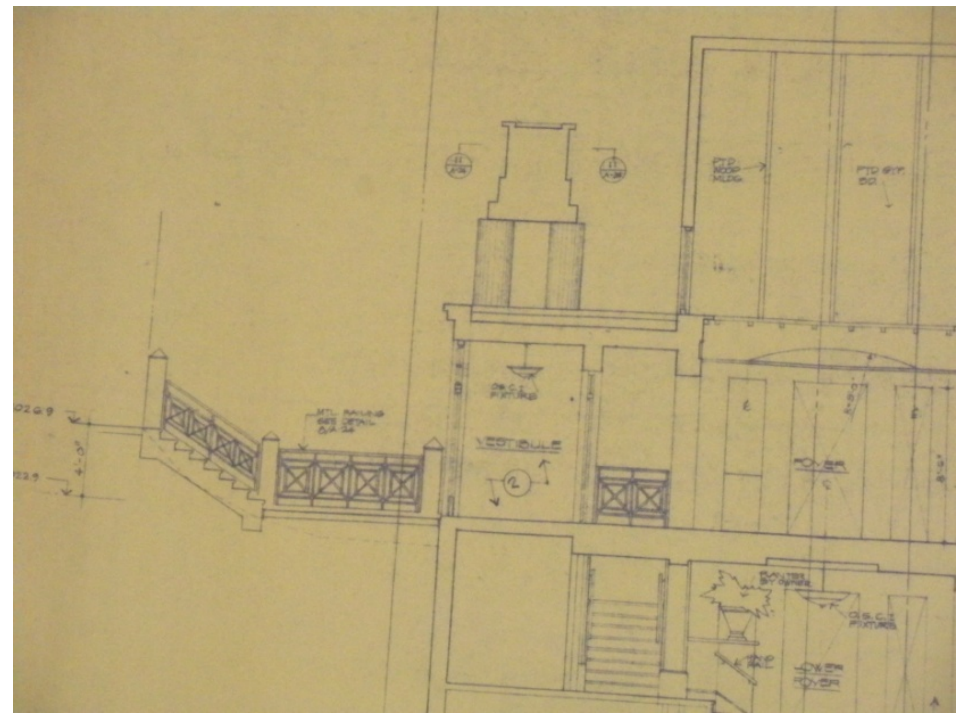

Plate 64. Architect’s plan for tholus supported by two columns (Photo by author)

This column is the most obviously classical in its reference of all the exterior elements and perhaps the most prominent element on the front side of the building. It sets the tone for the repeated classical references on both the exterior and interior of the building. The column's specific reference, perhaps to a particular Roman or Greek structure, is debatable. One suggestion is the Choragic Monument of Lysicrates (plate 65), erected by Lysicrates, a patron of 
musical performances, near the Acropolis in Athens in the fourth century B.C.E. ${ }^{64}$

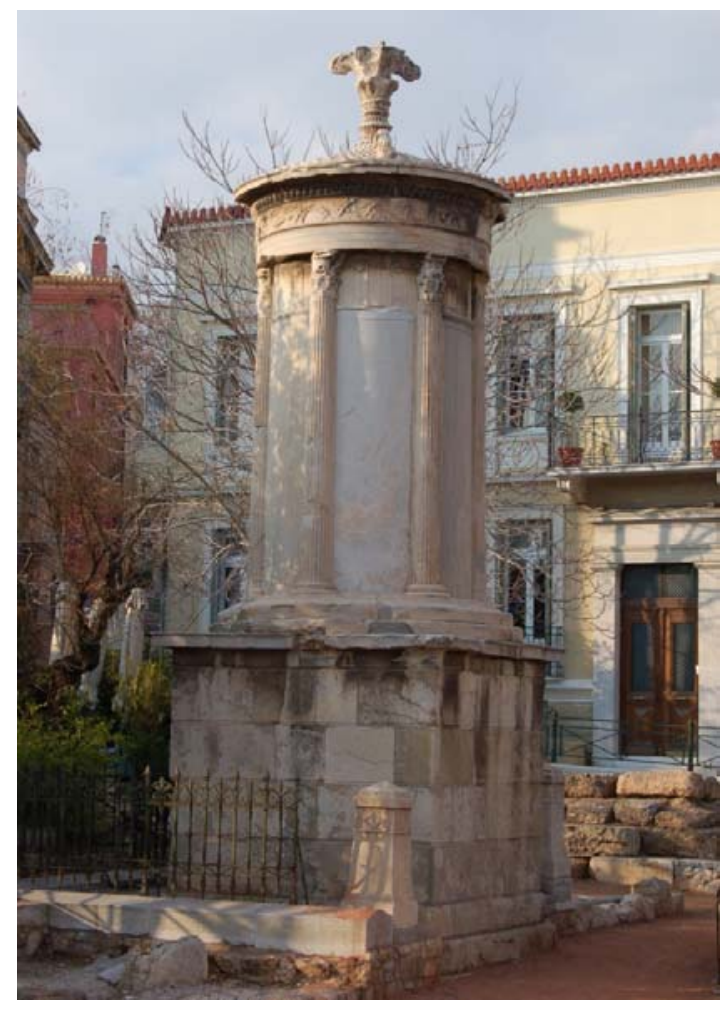

Plate 65. Choragic Monument of Lysicrates, Athens, Greece, c. 334 B.C.E.

Lysicrates' monument is a circular structure in the Corinthian order and served as a monument to a first prize received by a theatrical performance he sponsored. This element of the Erickson Center certainly resembles Lysicrates’ monument, but there are other plausible references (that may be combined with this one, since Graves's references are symbolic and not literal). There were pedestals above the pediment over the entryway of many country estates in Palladio's time (plate 66).

\footnotetext{
${ }^{64}$ This idea was suggested by Erin Bailey while she was a student in art history at West Virginia University.
} 


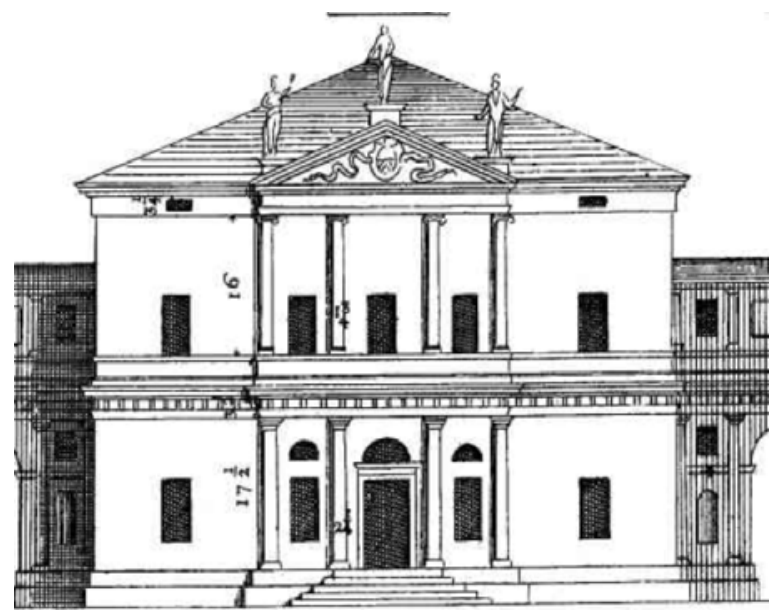

Plate 66. Country house of a noble Venetian

This pedestal supported a sculpture and was echoed by pedestals supporting sculptures at each end of the roof. Because of the Erickson Center's relation to the country estate, this reference is a likely, or at least an apt, one. The fact that there is no sculpture atop this Erickson Center column only serves to reinforce Graves’s style as referential, rather than literal. By presenting the viewer with only the column, Graves leaves his meaning open to interpretation while still making a clear reference to the classical column in all its possible functions. (These pedestals and sculptures above the pediment appear as far back as the Temple of Jupiter Capitolinus in Rome, 509 B.C.E., but the later villa reference suits the country estate idea in the Erickson Center.)

It also is worth noting a third possible reference. During his two years in Italy on the Prix de Rome, Graves collected inkwell replicas of the Temple of Vesta in Rome. He also photographed the temple ruins. He still displays the inkwells in his Princeton home (plate 67). ${ }^{65}$

65 Ambroziak, Michael Graves, 4. 


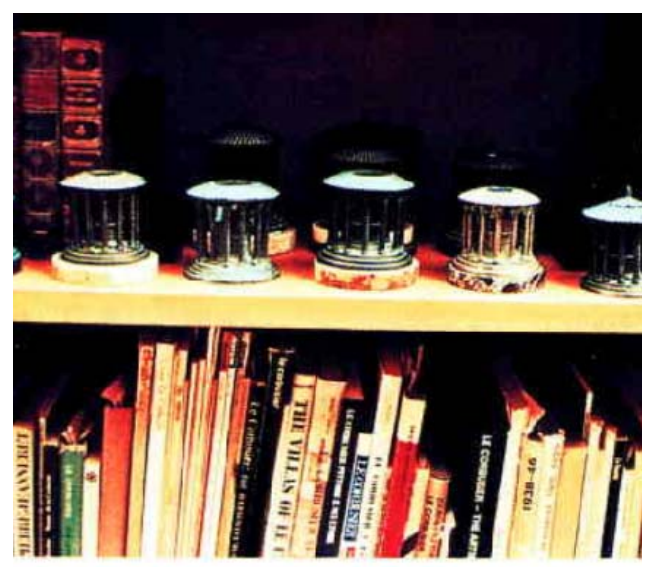

Plate 67. Graves's inkwells replicas of the Temple of Vesta

The similarity of the shape of the Temple of Vesta to the tholus above the Erickson entrance, in light of Graves's long-standing interest in this temple, makes it a likely influence on the tholus, also. The Temple of Vesta, like the Choragic Monument of Lysicrates, is a cylindrical shape and could have been an inspiration for this element.

A similar temple that Graves is likely to have seen is an even better reference: the Temple of Venus in the Villa Adriana (Hadrian's Villa) in Tivoli, Italy, 113-late 130s (plates 68 \& 69). Its Doric order is more in line with the Erickson Center, particularly the frieze with its metopes and triglyphs, a pattern that is repeated inside the Erickson Center. Repeated inside on the back wall of the Great Hall, above the fireplace along with the metopes and triglyphs, is the pattern on the tholus' shaft in relief (plate 70). This repeated pattern in the Great Hall aligns directly with the tholus. As with Grave's earlier Plocek House, he has moved elements or, in this case, repeated them in other parts of the building, in order to cause the viewer to relate the parts. He does not do this in the same way Mies would, by creating a comprehensive design that is used consistently throughout, but by repeating individual elements, sometimes in unexpected places, throughout. ${ }^{66}$ This use of the Greek metope and triglyph motif is indicative of Graves's

\footnotetext{
${ }^{66}$ Norberg-Schulz, "Michael Graves and the Language of Architecture,” 9.
} 
reference to Greek, as well as Roman, elements. It is appropriate, though, given that the Temple of Venus was part of the villa of the Roman emperor Hadrian, who had an obsession with Greek architecture.

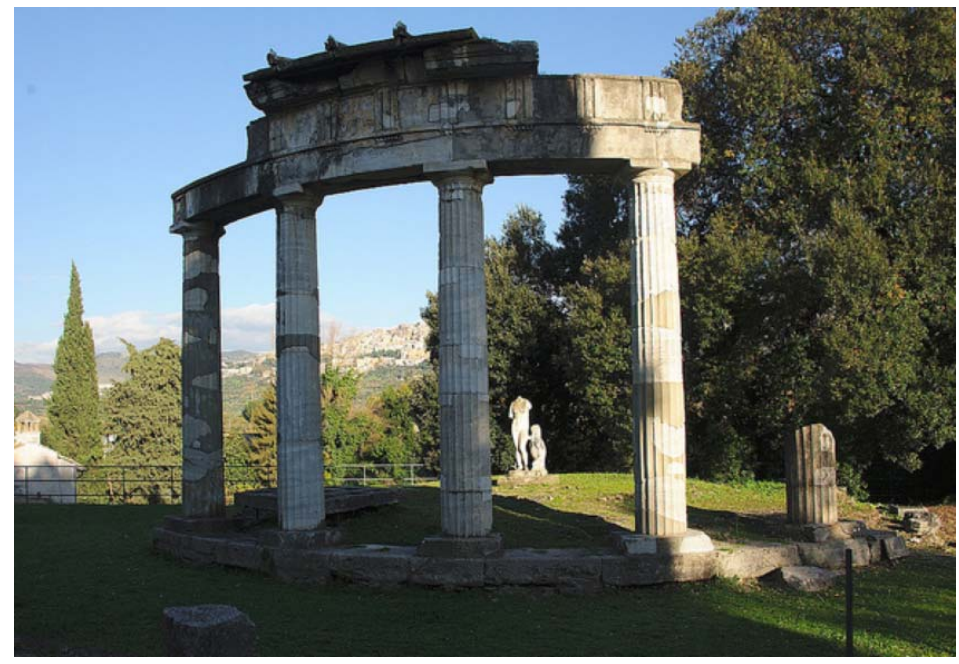

Plate 68. Temple of Venus, Hadrian’s Villa, Tivoli, Italy, second century A.D.

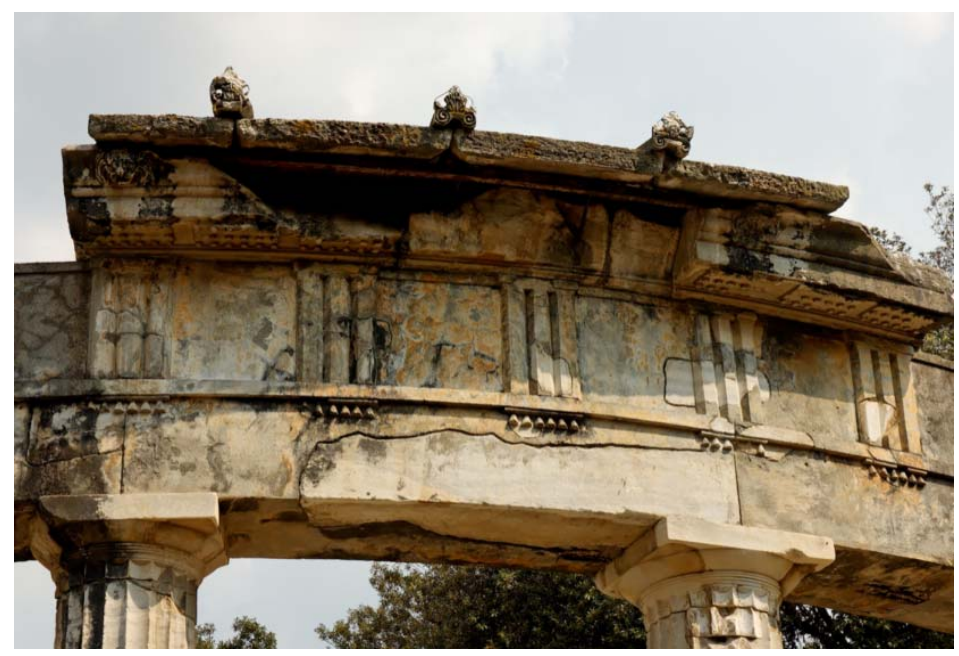

Plate 69. Temple of Venus detail, metopes and triglyphs 


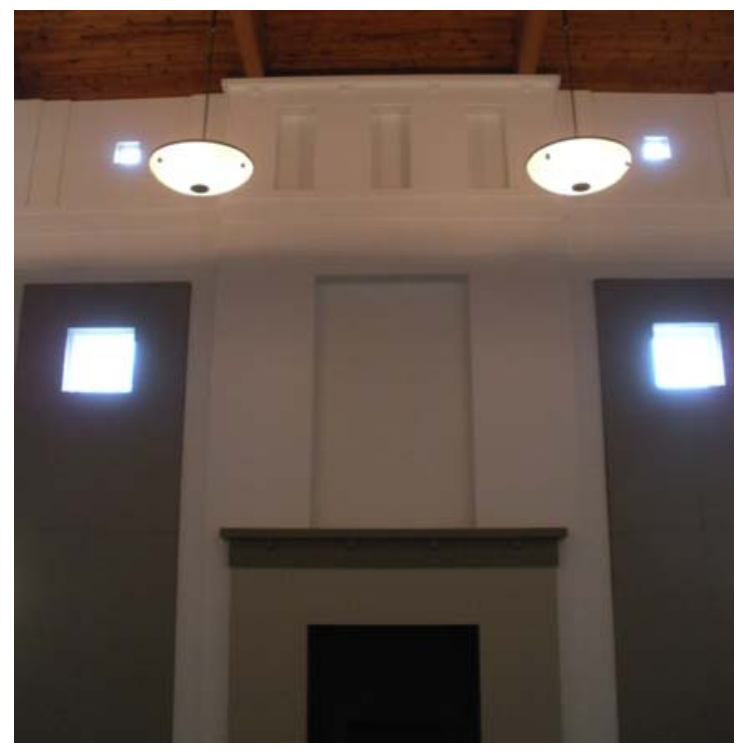

Plate 70. Erickson Alumni Center frieze, Great Hall (Photo by author)

Moving out in both directions from the entrance, the exterior of the building is symmetrical, with geometric shapes representing windows (even where there are none), shutters (or post and lintels), and stonework (oversized) (plate 63). Directly behind the tholus is a large (not quite equilateral) triangular pediment shape resembling a dormer but too large to be one. A smaller “dormer" sits on each side of the larger, central one, and all three refer to dormers common in country houses, as well as to the classical pediment shape. Toward the bottom of each dormer sits a window that allows light into entryway just inside the building. Near the apex of each triangle, a thin vertical rectangular shape is inset and suggests an opening. This shape echoes the shapes on either side of the front door, which sit above functional tall vertical windows. The faux windows, or niches, are echoed in the design around the tholus, where they form both a column-within-a-column design and the flutes of the shaft.

Both the functional and the faux windows are the "cookie cutter" type (of Adolf Loos and the Modernists) ${ }^{67}$ which refer back, in turn, to classical glassless windows, usually placed so as to focus the sun on specific points at certain times of the day. This type of window is used

${ }^{67}$ The Modernist window has no frame or sill, just a rectangular opening with a single plane of glass. 
throughout the building, in combination with the framed four-pane window reminiscent of a house.

Above each gridded trellis is a post and lintel design. The walls of the building, on all sides, are cut and painted so that they appear to be constructed out of large stones like those used in ancient Rome and Greece (and like bricks). The building was repainted in new colors when its function changed in 2010-11. The exterior walls originally were painted in bands of two alternating earth tones, adobe and salmon (plate 71). This pattern is reminiscent of the color pattern resulting from the Roman technique (first century B.C.E.-seventh century A.D.) of alternating bands of long bricks ("Roman brick") with wider bands of mortar containing stones arranged in a diamond pattern (plates $72 \& 73){ }^{68}$



Plate 71. Erickson Alumni Center exterior wall decoration (Photo by Michael Slaven)

${ }^{68}$ The diamond pattern gives the effect of netting (reticulatum in Latin), thus the name opus (work in Latin) reticulatum. 


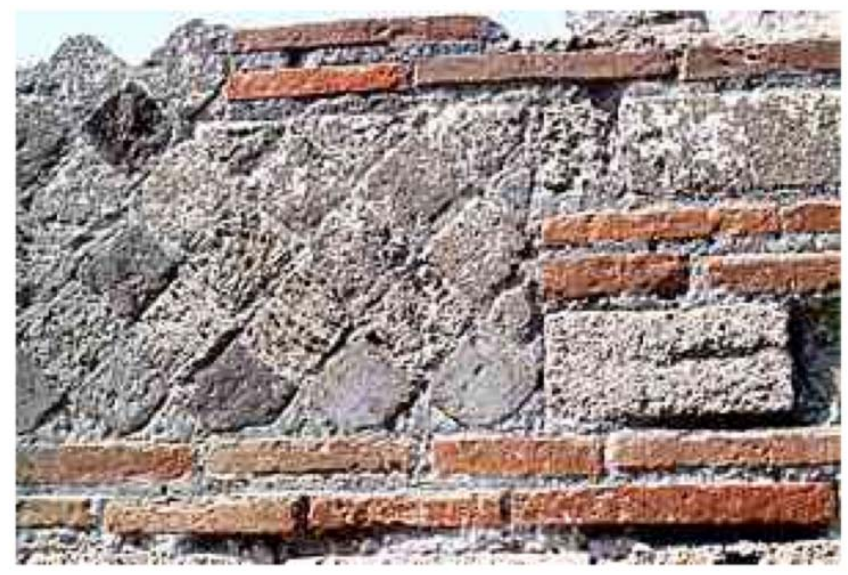

Opus reticulatum, Pompeii. (VRoma: Lisanne Marshall)

Plate 72. Roman wall construction detail

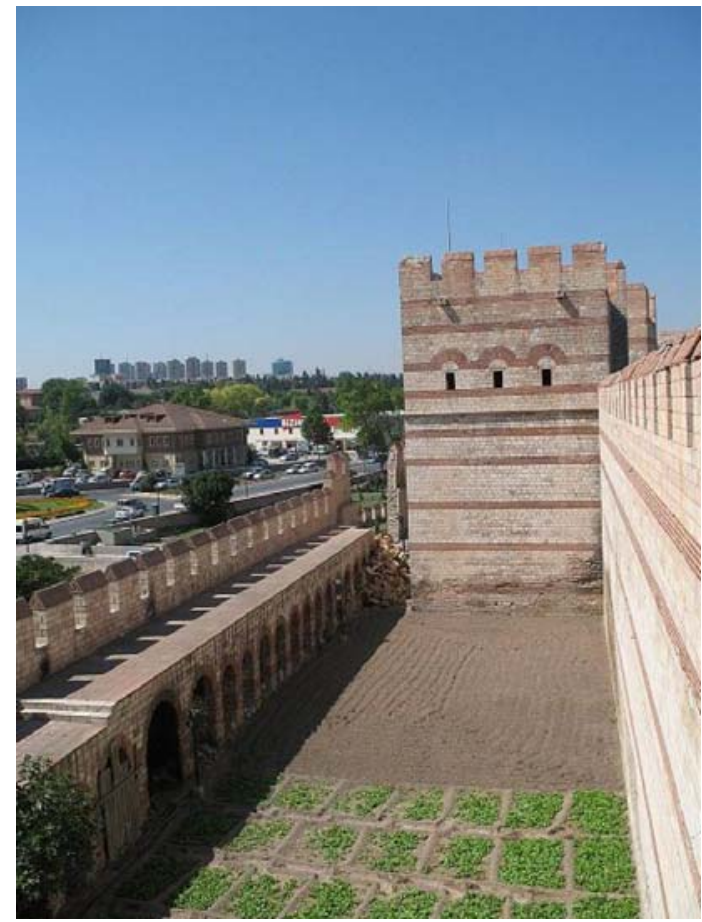

Plate 73. Theodosian Wall built under Roman Emperor Constantine, Istanbul, Turkey, fourth century A.D.

Most of the walls that are not painted in this fashion are a light ocher color, with the same sandy-looking finish. Graves’s use of color emphasizes his strong geometric shapes by creating clear, hard-lined definition between elements or areas of different color. Colors are limited, and the same color often is repeated on like shapes (such as the ocher triangles). The difference in color from one shape to another makes each shape pop out as a self-contained element, 
emphasizing the individual reference (symbolism) of each.

One enters the building, passing under the large column, through a small passageway with stairs on each side. This plan is similar to the plan for ancient Roman private houses. ${ }^{69}$ Straight ahead, the passageway opens into a small foyer, a square room with a high ceiling (with pedimental shapes), dentil molding, and repeated squares near the top of the walls. The triangle and square are repeated here, as on the exterior of the building. Beyond this room is a hallway with small square windows overlooking the large central hall that is the focus of the building's interior space. (Originally, these windows had no glass but were open like windows in many classical buildings; fire codes demanded that glass be added.)

Directly below this hallway overlooking the great central hall, accessible via the stairways on either side of the entry passageway, is a sort of "colonnade" formed by repeated rectangular openings framed by supporting piers (plate 74$).{ }^{70}$ (Some of the openings have since been walled off in preparation for the buildings new function.) As one looks from right to left, one sees a hallway reminiscent of the classical colonnade.

\footnotetext{
69 Andrea Palladio, The Four Books of Architecture (New York: Dover Publications, Inc., 1965), 43.

70 This colonnade is made by repeated rectangular openings cut into a long wall, the reverse of the usual colonnade, made of structural piers and the resulting spaces between.
} 


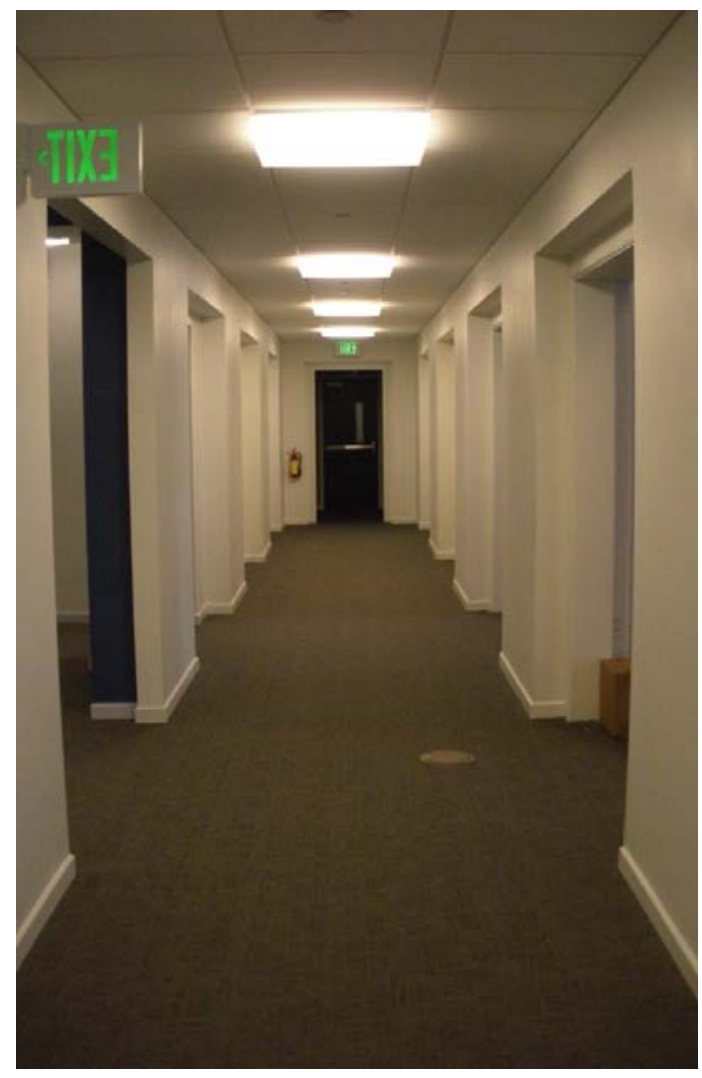

Plate 74. Erickson Alumni Center downstairs hallway “colonnade” with piers (Photo by author)

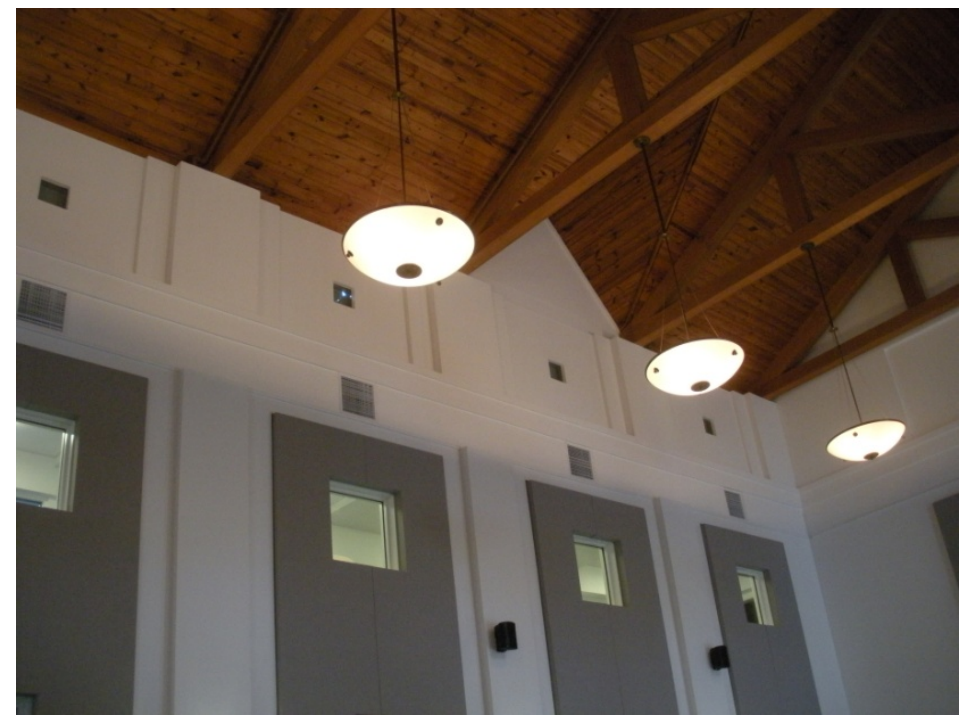

Plate 75. Erickson Alumni Center Great Hall ceiling beams and pedimental shapes, acoustic panels added later (Photo by author)

Inside the central hall, the walls are decorated with pilasters, marked in relief and color but not representing any function (plate 75). Again, Graves repeats the same geometric shapes: 
triangle, square, and rectangle. In the banquet room, the windows are small and placed high on the wall, as they were in the open atriums in classical buildings; they form a clerestory.

The exposed framing for the roof is the major reference inside the building to the contemporary country house and presents yet another set of repeated triangular shapes. Graves has abutted the wooden beams with more triangular shapes where the walls meet the ceiling. Once again, high square windows allow light to enter through relatively small openings.

Above a "cookie cutter" fireplace (with the clean lines of a Modernist aesthetic) is a niche, and above that, the frieze that echoes the tholus at the building's entrance (referenced earlier in this study). The frieze, with its metopes and triglyphs, is repeated throughout the Great Hall. The fireplace itself is raised, perhaps to give it more importance. The base consists of three steps, reminiscent of a classical stylobate (plate 76). It looks like an altar, possibly with reference to classical temples and sacrifices, but it also serves as a hearth for the country house.

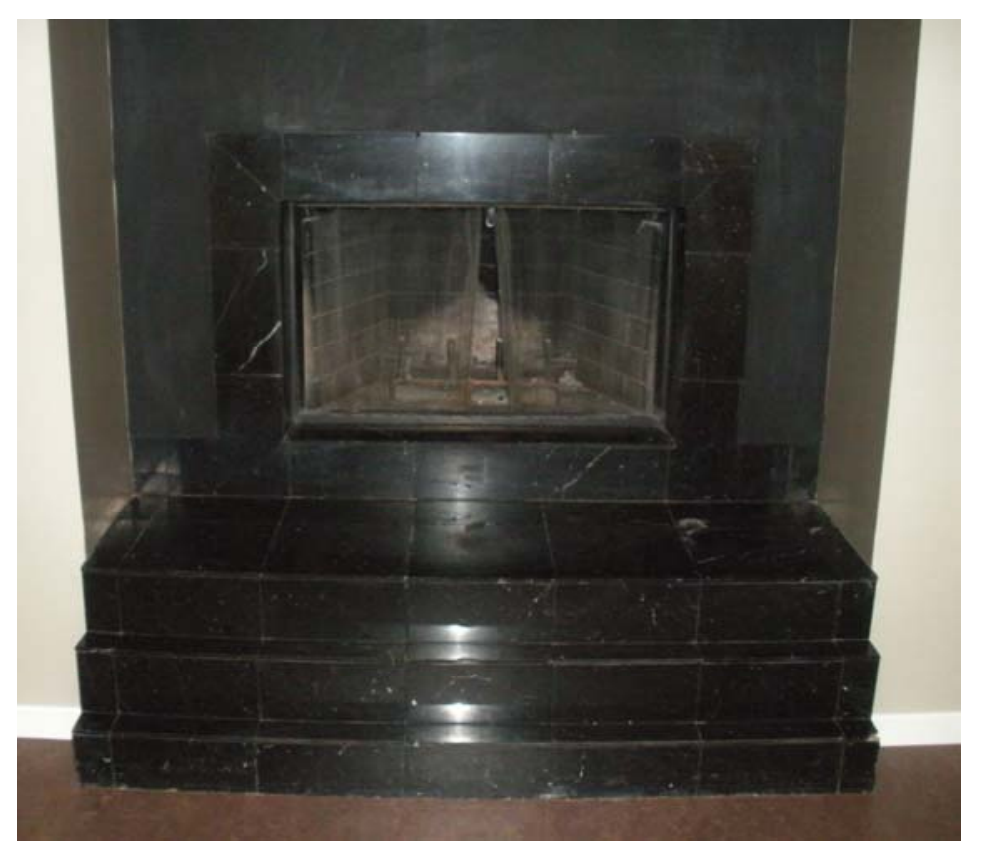

Plate 76. Erickson Alumni Center Great Hall fireplace (Photo by author)

The mantel above the fireplace is oversized, another way that Graves emphasizes important referential elements, but the fireplace itself is on a human scale. 
Graves designed both the outside and inside of the building, including some of the lighting fixtures, chairs, and one conference table (though not designed specifically for this building). In the conference table, one can see many of the same classical features present in the architecture of the building: dentil molding under the table top (capital) and round shafts as legs (columns shafts) (plate 77).

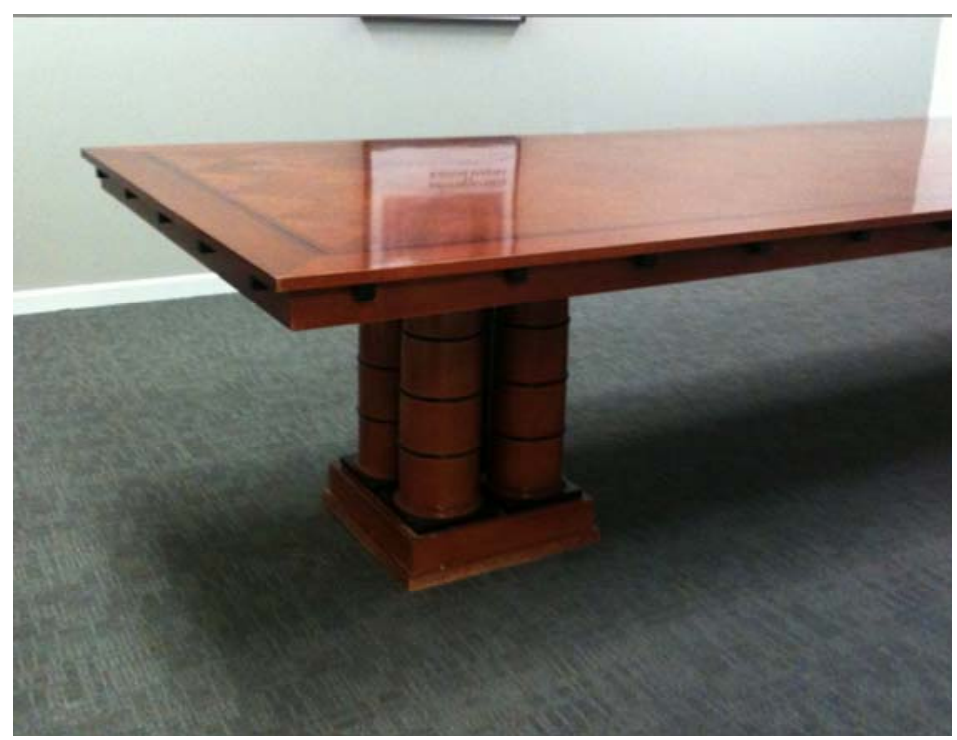

Plate 77. Graves table with dentil molding and “column” legs (Photo by author)

On the exterior rear façade, the most obvious classical reference is the oversized pedimental shapes supported by double pilasters, one on either side of the chimney (plate 78). They are supported by column shapes. These elements have a building block appearance, and similarities can be seen to the children’s blocks designed later by Graves (plate 79). 


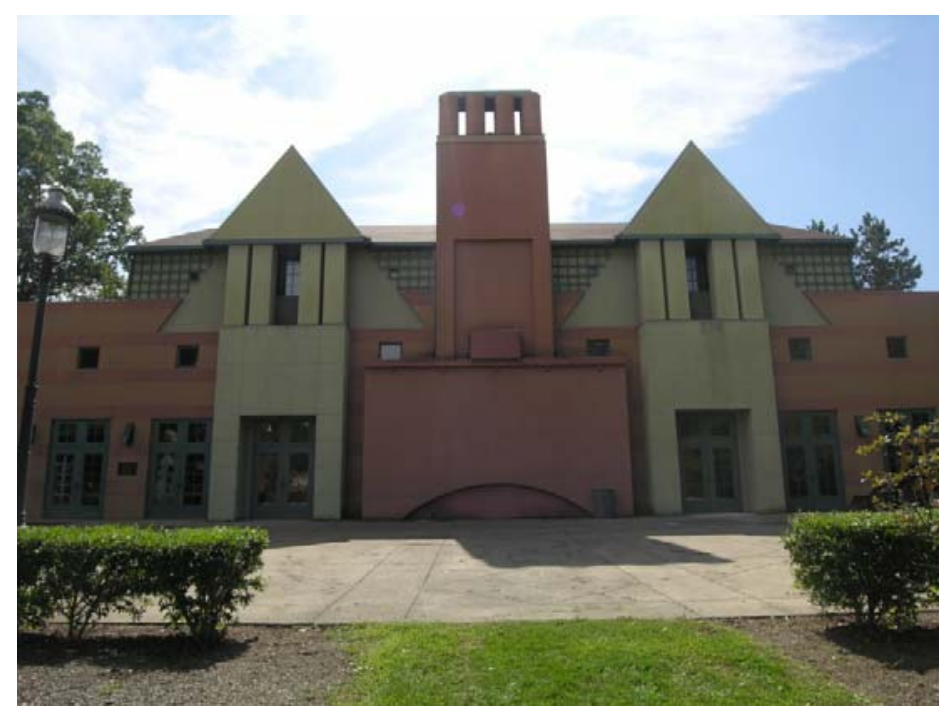

Plate 78. Erickson Alumni Center rear façade (Photo by author)

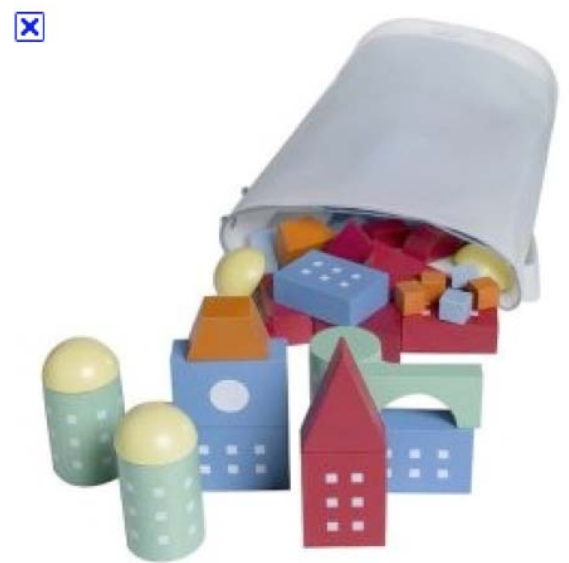

Plate 79. Graves, children’s building blocks

The fireplace in the Great Hall is exaggerated even further on the exterior, through the extreme exaggerated scale of the chimney (plate 78). On top of the chimney are eight flues, representing chimney pots or industrial chimney stacks. (Perhaps this is a reference also to the Modernist industrial aesthetic.) All along the wall are repeated square shapes, again, forming a kind of clerestory or frieze across the entire rear façade. The chimney shape makes reference to several architectural periods. At the bottom is an arched span reminiscent of a Roman arch. This 
arch is reminiscent of the hearth but also reflects back to a feature used commonly in classical architecture, the relieving arch, built over the lintel of a window or doorway to take pressure off the opening. The Tomb of Agamemnon, in Mycenae, Greece (plate 80), employs a very early relieving arch, and on the inside of the portico of the Pantheon, the architraves have such arches.

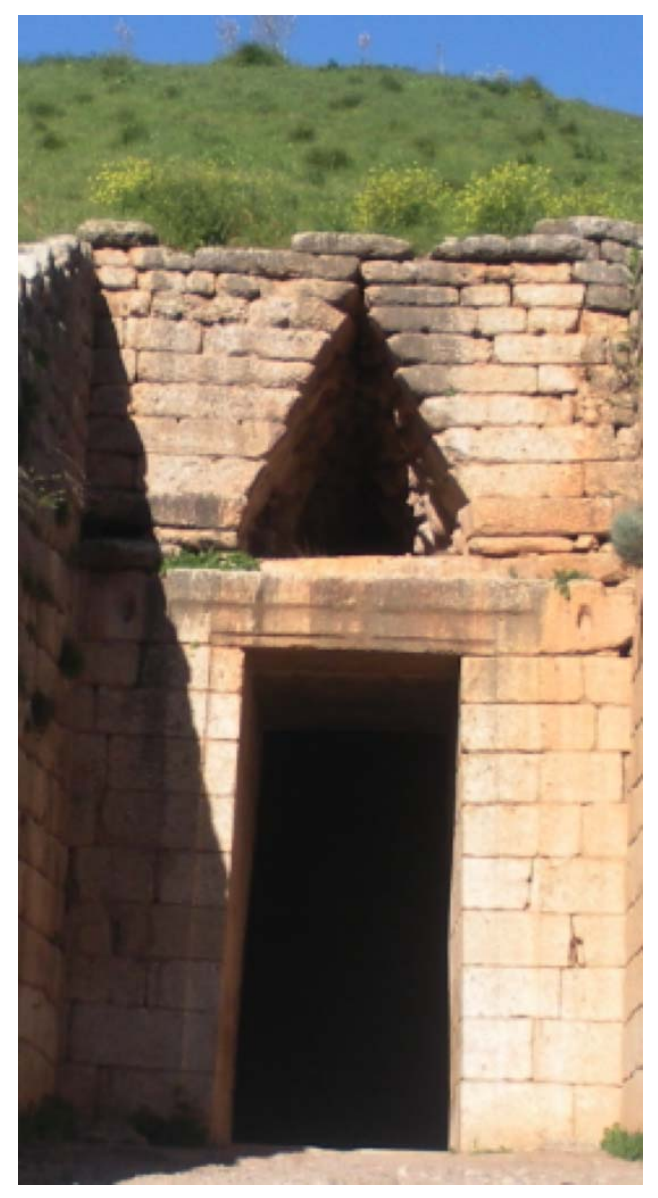

Plate 80. Tomb of Agamemnon, Mycenae, Greece, c.1250 B.C.E. (Photo by author)

Between the chimney and the pediments are areas where the trellis grid is repeated but breaks off suddenly to expose the surface beneath, a device used by Postmodernists to show actual structure and, here, possibly to show the classical foundation under the Modernist trellises. Also, the break in the trellises forms two sets of triangles, which offer a repetition of the pediment and emphasize the use of basic shapes (plate 78). Color again is used as a reference to the colors Graves observed during his extended time in Italy. 
Much of the visual interest of the building depends on the regularity and repetition of geometric shapes and on frontal symmetry (on the rear of the building also). There is attention to proportion, but it focuses on exaggeration, playing with the size of one element as it relates to another and to its classical prototype. The classical elements are present but in unexpected combinations and locations. While there is some fun for the educated eye to engage in locating all the classical references, there is no clear picture of how these elements relate to each other or to the design as a whole. Do the two types of architecture combine to make a homey alumni center that is aggrandized by its classical references? Graves recognizes that “[a]lthough analogies drawn between one cultural form and another prove somewhat difficult, they nevertheless allow associations that would otherwise be impossible." ${ }^{, 71}$ He compares architectural language to literature and its use of symbolism or semiotics. Postmodernism asks that we re-learn or re-activate the classical languages in order to be able to read contemporary architecture. $^{72}$

Graves goes on to say that there are two languages: the internal and the external. The internal is made up of the elements necessary to construct a building, its structure, materials used, the pragmatic or standard language. The external is the decoration, the cultural or ritual elements, the poetic language. He say both are necessary, that "the components of architecture have not only derived from pragmatic necessity [the standard language], but also evolved from symbolic sources [the poetic language]. The reason for the choice of classical as a part of the language of Postmodernism seems the same, in the end, as its choice in Modernism. It is the basis, accepted and recognizable to most people, of western culture. It provides, as such, a common language, whether that language be expressed in ideological or literal terms.

\footnotetext{
${ }^{71}$ Graves, “A Case for Figurative Architecture,” 11.

${ }^{72}$ Ivan Zaknic, bion.mit.edu/ejournals/aJa-m/Architronic/l/vlnJ/13. "Michael Graves.”
} 


\section{Conclusion}

This study has shown how architects Ludwig Mies van der Rohe and Michael Graves serve as representative examples of the ways in which classical elements and ideas informed the work of Modern and Postmodern architects. Mies’s Richard King Mellon Hall in Pittsburgh, Pennsylvania, and Graves’s Erickson Alumni Center in Morgantown, West Virginia, both university buildings, have served as examples by which to investigate these influences. This is the first in-depth study of each of these two buildings through the lens of classicism, and each is characteristic of its respective architect's use of these influences.

Both Mies and Graves, though each is tied to Greek and Roman architecture, respectively, borrowed from both styles. Mies distilled classical values and architectural elements down to their essence and then expressed them in Modern materials. He synthesized the geometry and the grid of the Greeks with the Roman elements to which he was exposed early in his life, in order to develop an architectural system that would transcend place and time. This was the Modernist abstract goal.

Graves has embraced the eclecticism that resulted from the Roman practice of borrowing ideas and techniques from others. He has rejected the Modernist ideal in favor of an architecture that speaks, in the vernacular, to its roots. The classical elements he uses are symbols, part of a language that roots buildings to a particular time and place, places them in context. Unlike the Modernists, who lived in a time of world war and sought to make that world a better place through lofty architectural ideals, the Postmodernists sought (and still seek) to bring architecture back down to earth, to allow it to communicate with the viewer, to give it a reality and a solidity that Modernist architecture lacked. 


\section{Bibliography}

---, “Dedication Program for Richard King Mellon Hall of Science.” Pittsburgh, Pennsylvania.

Adams, Margaret B. “A place to call home.” Case Currents (November/December 1991): 8-9.

Ambroziak, Brian. Michael Graves: Images of a Grand Tour. New York: Princeton Architectural Press, 2005.

Bergdoll, Barry. Karl Friedruch Schinkel: An Architecture for Prussia. New York: Rizzoli, 1994.

Blake, Peter. The Master Builders: Le Corbusier, Mies van der Rohe, Frank Lloyd Wright New York: W. W. Norton \& Company, Inc., 1960 (revised edition 1976).

Blaser, Werner. Mies van der Rohe. New York: Praeger Publishers, 1965 (revised edition 1972).

Blaser, Werner. Mies van der Rohe: The Art of Structure. New York: Whitney Library of Design, 1994.

Briley, Kathie. "WVU Alumni Center: Decorator Predicts Buildings Will Be Controversial.” The Intelligencer (August 21, 1986): 8.

Brolin, Brent C. Architecture in Context: fitting new buildings with old. New York: Van Nostrand Reinhold Company, 1980.

Buck, Alex, and Vogt, Matthias, eds. Michael Graves: Design Monograph 3. Berlin: Ernst \& Sohn, 1994.

Carubia, Robert J. “An Architectural Programming Statement for the Proposed West Virginia University Alumni Center.” (March 1984).

Clarke, David. The Architecture of Alienation. New Brunswick and London: Transaction Publishers, 1994. Review of George Hersey, The Lost Meaning of Classical Architecture, MIT Press.

Conrads, Ulrich, Programs and Manifestoes on $20^{\text {th }}$-Century Architecture. Trans. Michael Bullock. Cambridge, MA: The MIT Press, 1964.

Colomina, Beatriz. “Mies Not,” in The Presence of Mies, ed. Detlef Mertins. New York: Princeton Architectural Press, 1994.

Curtis, William J. R. Modern Architecture Since 1900 (third edition). London: Phaidon Press Limited, 1982, 1987, 1986.

Curtis, William. “Modern Transformations of Classicism.” Architectural Review (August 1984). 
Daleo, Franc. “Mies and the Greatness of Modernity.” Casabella, vol. 65, no. 692 (September 2001): 45, 90-1.

Daza, Ricardo. Looking for Mies. Basel: ACTAR Barcelona, Birkhauser -Publishers for Architecture, 2000.

DePollo, Janice. “Michael Graves, Architect.” Panorama (November 9, 1986): 12-3.

Doremus, Thomas, Classical Styles in Modern Architecture from Colonnade to Disjointed Space. New York: Van Nostrand, 1994.

Drexler, Arthur. Ludwig Mies van del’ Rohe. New York: George Braziller, Inc., 1960.

Duquesne University, 1968. "Duquesne Science Hall chosen 'Lab of the Year.'” Industrial Research (May 1969): 27-8.

Duquesne University. www.duq.edu/campusmap/mellon.htm. "Richard King Mellon Hall of Science.”

Gaskie, Margaret. “Independent Studies.” Architectural Record (March 1987).

Goldberger, Paul. On the Rise: Architecture and Design in a Postmodern Age. New York: Times Books, 1983.

Graves, Michael. “Has Postmodernism Reached Its Limit?” Architectural Digest (April 1988): 6-10.

Graves, Michael. “A Case for Figurative Architecture,” in Michael Graves: Projects and Buildings 1966-1981, eds. Karen Vogel Wheeler, Peter Arnell, and Ted Bickford. New York: Rizzoli, 1982.

Hanfmann, George M. A. Roman Art: A Modern Survey of the Art of Imperial Rome. New York: W. W. Norton \& Company, Inc., 1975.

Harris, Karsten. The Ethical Function of Architecture. Cambridge, Massachusetts: The MIT Press, 1997.

Hays, K. Michael, ed. Architectural Theory since 1968. Cambridge, Massachusetts: The MIT Press, 2000.

Hearn, Fik, Ideas That Shaped Buildings. Cambridge, MA, and London: The MIT Press, 2003.

Hilberseimer, L. Mies van der Rohe. Chicago: Paul Theobold and Company, 1956.

Holloway, R. Ross. A View of Greek Art. Providence, Rhode Island: 1973.

Jencks, Charles. Post Modernism: The New Classicism in Art and Architecture. New York: Rizzoli, 1987. 
Johnson, Philip. Mies van der Rohe. New York: The Museum of Modem Art, 1947.

Jordy, William. "The Aftermath of the Bauhaus in America: Gropius, Mies, and Breuer." Perspectives in American History, 2 (1968): 485,526.

Kraus, Rosalind. 'The Grid, The/Cloud!, and The Detail.” Mertins, Detlef, ed. The Presence of Mies. New York: Princeton Architectural Press, 1994, 133-47.

Kries, Mateo. "Pure Form Only?” Architectural Design, vol. 72, no. 4 (July 2002)” 14-16. Kurokawa, Kisho. The Philosophy of Symbiosis. London: Academic Editions, 1994.

Le Corbusier. Frederick Etchells, trans. Towards a New Architecture. London: 1927.

Lifson, Edward. "How Truth and Beauty Moved from the Classical to the Modern. From Athens to Berlin to Chicago: From the Acropolis to Schinkel to Mies.” Master's thesis, The University of Southern California, 2009.

Lillyman, William J., Moriarty, Marilyn F., and Neuman, David J., eds. Critical Architecture and Contemporary Culture. New York: Oxford University Press, 1994.

Lobiondo. Maria. www.princeton.com/patron/mgraves.html. "Michael Graves “Archetype of the 90's."

Matthews, Kevin and Artifice, Inc. www.GreatBuildings.com/architectslMichael_Graves.html. "Michael Graves."

Mertins, Detlef. "Mies’s Skyscraper "Project”: Towards the Redemption of Technical Structure," in The Presence of Mies. ed. Detlef Mertins. New York: Princeton Architectural Press, 1994.

Mertins, Detlef, ed. The Presence of Mies. New York: Princeton Architectural Press, 1994.

Moore, Felicity St. John. Classical Modernism: The George Bell Circle. Melbourne: National Gallery of Victoria, 1992.

Nesbitt, Kate, ed, Theorizing a New Agenda for Architecture: An Anthology of Architectural Theory 1965-1995. New York, Princeton Architectural Press, 1996.

---. "New Skyscraper on Park Avenue To Be First Sheathed in Bronze; 38-Story House of Seagram Will Use 3,200,000 Pounds of Alloy in Outer Walls Colored for Weathering." The New York Times. (March 2, 1956).

Nichols, Karen Vogel, Burke, Patrick J., and Hancock, Caroline, eds., Michael Graves: Buildings and Projects 1982-1989. New York: Princeton Architectural Press, 1990.

Palladio, Andrea. The Four Books of Architecture. New York: Dover Publications, Inc., 1965. 
Peterson, Merle, Architect, AlA, Manager for Planning and Programming, Planning, Design, and Construction, West Virginia University Physical Plant, Morgantown, West Virginia. Personal interview. November 16, 2000.

Powell, Kenneth. Graves Residence: Michael Graves. London: Phaidon Press Limited, 1995.

Puente, Moisés, ed. Conversations with Mies van der Rohe. New York: Princeton Architectural Press, 2008.

Rishel, Joseph. The Spirit that Gives Life: A History of Duquesne University. Pittsburgh: Duquesne

Rodenwaldt, Gerhart. Griechisches und Romissches in Berkiner Bauten des Klassizismus. Berlin: Walter de Gruyter \& Co., 1956).

Schulze, Franz. Mies van der Rohe: A Critical Biography. Chicago and London: The University of Chicago Press, 1985.

Sogg, Daniel. “Classical harmony.” Art and Antiques (April 1999): 60-9.

Spaeth, David. Mies van der Rohe. New York: Rizzoli 1985.

Stevens, Garry. The Reasoning Architect: Mathematics and Science in Design. New York: McGraw-Hill Publishing Company, 1990.

Stevenson. Neil. Annotated Guides: Architecture. London: DK Publishing, Inc., 1997.

Stuart, James. The Antiquities of Athens and Other Monuments of Greece. 1892.

Sullivan. Mary Ann. "Richard King Mellon Hall of Science, Duquesne University.” www.bluffton.edu/-sullivan/mies/miespitt.html

Summerson, John. The Classical Language of Architecture. Cambridge, Massachusetts: The MIT Press, 1963.

Venturi, Robert, Brown, Denise Scott, and Izenour, Steven. Learning from Las Vegas. Cambridge, MA: MIT Press, 1972.

Vitruvius, Ten Books on Architecture, trans. Ingrid D. Rowland. Cambridge: Cambridge University Press, 1999.

Wheeler, Karen Vogel, Arnell, Peter, and Bickford, Ted, eds. Michael Graves: Projects and Buildings 1966-1981. New York: Rizzoli, 1982.

Whiffen, Marcus and Koeper, Frederick. American Architecture 1607-1976. Cambridge, Massachusetts: The MIT Press, 1981.

Whitford, Frank. Bauhaus. London: Thames and Hudson, 1984. 
Zaknic, Ivan. "Michael Graves: Restoring a Language to Architecture.” bion.mit.edu/ejoumals/ala-m/Architronic/llvlnl.13.

\section{John $\mathrm{H}$.

